THE RECESSION OF THE LAST ICE SHEET IN NEW ENGLAND

ERNST ANTEVS

工沙-

AMERICAN GEOGRAPHICAL SOCIETY

RESEARCH SERIES NO. I I 



$$
\begin{aligned}
& 910.673 \\
& A 42 \\
& n 0.11
\end{aligned}
$$




LAST ICE RECESSION IN

NEW ENGLAND 



\section{AMERICAN GEOGRAPHICAL SOCIETY}

RESEARCH SERIES NO. I I

W. L. G. JOERG, Editor

\section{THE RECESSION OF THE LAST ICE SHEET IN NEW ENGLAND}

BY

ERNST ANTEVS

University of Stockholm

WITH A PREFACE AND CONTRIBUTIONS

BY

J. W. GOLDTHWAIT

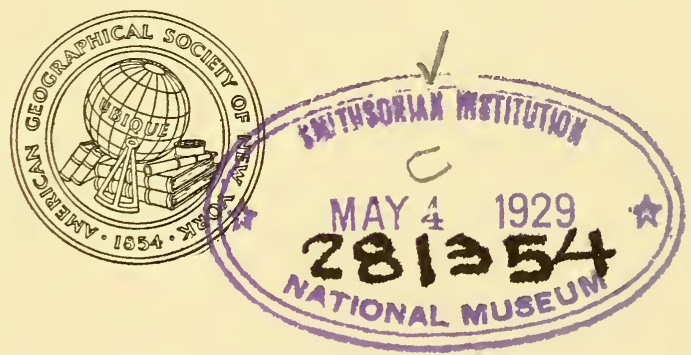

AMERICAN GEOGRAPHICAL SOCIETY

BROADWAY AT I 56TH STREET

NEW YORK

I 922 
COPYRIGHT, I922

BY

THE AMERICAN GEOGRAPHICAL SOCIETY OF NEW YORK

THE CONDE NAST PRESS GREENWICH, CONN. 


\section{CONTENTS}

CHAPTER

PAGE

Preface, By J. IV. Goldthwait . . . . . . vii

INTRODUCTION . . . . . . . . . . . . . xi

I Varve Clay, and the Method of Investigation I

II Conditions in New England During the DeposiTION OF THE VARVE Clay . . . . . . . . . . 7

III Description of the Sections at the Localities StUdied . . . . . . . . . . . . . II I I

IV The Normal Curve . . . . . . . . . . . . . . 47

V The Connections . . . . . . . . . . . . 64

VI Abyormal Varves, and Disturbances in the Clay 69

VII The Rate of Recession and Conditions ConTROLLING RECESSION . . . . . . . . . . . 74

VIII The Climate During the Recession, and CliMAtic Periodicity . . . . . . . . . . . . 89

IX The Bearing of These Studies on Previous Work and on New Problems . . . . . . . . . . . 94

Explanation of the Map Illustrating the ReCession of the Last Ice Sheet from New England and New York, by J. W. Goldthwait . . IO4 List OF REFERENCES . . . . . . . . . . IO8 INDEX . . . . . . . . . . . . II7 



\section{LIST OF ILLUSTRATIONS}

FIG.

PAGE

I Manner of deposition of varve clay . . . . . . .

2 An exposure of varve clay . . . . . . . . facing

3 View showing the method of measuring the clay layers . . . . . . . . . . . . facing

4 Sample of measurement made in the field and curve constructed from it in the office . . . . . . .

5-I2 Maps showing the position of the localities examined in the Connecticut Valley. Scale, I:160,000 . . .

I3 Map showing the position of the localities examined in the Merrimac Valley. Scale, I:160,000 . . . .

I4 Curves showing three drainages of ice-ponded lakes into the Connecticut River above the Passumpsic

I 5 Section at locality 24, southeast of Amherst, Mass,

I6 Part of curves at localities I9 and 20, Northampton, Mass.

I7 Annual rate of ice retreat in southern Finland, after Sauramo

I 8 Curve showing drainage during years 567 I-5676 recorded at locality $a$, Catskill, N. Y. . . . . . .

I9 Part of curves at localities 27 and 28 near Greenfield, Mass.

PL.

\section{Plates}

I-V [Normal curve, covering 4,400 years in $2 \mathrm{I}$ sections, recording the recession of the edge of the last ice sheet from Hartford, Conn., to St. Johnsbury, Vt. (At bottom of Pl. V, curves I-III, three groups of individual curves illustrating connections and correspondences within each group)] . . . . . . . . . At end

VI Map Illustrating the Recession of the Last Ice Sheet from New England and New York, compiled by J. W. Goldthwait. Scale, I : I,250,000 . . . . . At end 



\section{PREFACE}

Dr. Anters' study of the recession of the last ice sheet from New England is something new and significant. It differs so much, indeed, in method from previous studies by glacialists in America, and the range of its applications is so wide, that no brief introduction can quite do it justice. Fortunately, these methods are so simple that they are readily understood and put to practice. As for the broad application of such work as this to solving problems of glacial history and climate and the accompanying migrations of plants and animals and of primitive man, an attentive reader may form his own judgment.

Ever since Louis Agassiz conceived the idea of former continental ice sheets over northern Europe and North America, geologists of the two continents have been gathering evidences of them. New England, the home of Agassiz almost from the time when his glacial theory was announced until his death, presents varied and plentiful proof of glaciation. The grooves and striae on the rocks, the southward dispersion of stones and boulders, and the varieties of "drift" deposits had already been observed and speculated upon by Edward Hitchcock, W. W. Mather, C. T. Jackson, and other pioneers in New England and New York when Louis Agassiz advanced his theory of an ice sheet. Although they recognized the fact that the puzzling "drift phenomena" corresponded to records made by living glaciers, American geologists for twenty or thirty years hesitated to accept the new explanation, owing to the difficulty of conceiving of a glacier so thick and so extensive that it could spread its records continuously across uplands and valleys. The unhappy effect of an inhospitable attitude toward a new theory and new methods was clearly illustrated here during the period from I84I to 1870 , when the "glacial theory" was on probation. Lively discussions of it, as reported in contemporary proceedings of our scientific societies, betray the human tendency to judge 
a theory by the number and prestige of its adherents and converts instead of by careful and impartial consideration of the evidence. This experience, already forgotten in the subsequent development of a complete demonstration of the truth of Agassiz' theory, should keep us from committing a similar mistake in our attitude toward this new and surprising work of Dr. Antevs.

Whatever advance in science comes from such studies as this must be accredited in the first place to the genius of Baron Gerard De Geer of Stockholm. His discovery of a simple, graphic way to correlate layers of clay at one locality with the layers at another locality, and thus to identify them as the record of the same years, is the starting point for the new processes of study. In Europe the development of the new methods by De Geer and his associates, Lidén, Carlzon-Caldenius, Sandegren, Antevs, Sauramo, and others, has already indicated the possibility (a) of determining an exact time scale of late glacial and post-glacial time, (b) of reconstructing the position of the ice border more or less accurately during each year of its withdrawal, (c) of measuring the rate of its recession, in meters per year, (d) of detecting halts or zones of retarded recession even where these are not registered by recessional moraines, (e) of working out the complicated changes of drainage that took place as ponded waters were released and modern river systems inaugurated, and even (f) of computing with accuracy the rate of regional uplift of the region during the departure of the ice sheet. In short, De Geer and his colleagues have made great progress in the working out of a detailed history of the retirement of the border of the last land ice from northern Europe, of the evolution of climate, and of the migrations of plants, animals, and primitive man. The literature of these studies is but little known in America; and the few reviews and abstracts covering them suffer from lack of a first-hand knowledge of unpublished studies such as that which Dr. Antevs possesses and uses in this memoir to good advantage. It will be noticed that he sees limitations as well as wonderful possibilities in the methods inaugurated by De Geer. 
The student of glacial history, particularly in New England and New York, will discover in this study an amazing array of conclusions. Dr. Antevs has traced a series of clay layers which mark approximately 4,000 successive years up the Connecticut Valley from Hartford, Conn., to St. Johnsbury, Vt. He has found large parts of the same series duplicated in the Hudson and Merrimac Valleys. He has worked out successive positions of the receding ice border, after only a few months of field work, in a region where two generations of American geologists, baffled by the absence of definite moraines, have realized little or no success. The estimate of time occupied by this recession is a simple arithmetical count, expressed not in centuries but in years. Such accuracy can never be claimed for our computations of time from the Niagara gorge, where large factors are only imperfectly measurable. An investigation so precise in method and execution and so suggestive will give fresh impulse to our studies of Pleistocene glaciation. There is scarcely a problem of the history of this curious and interesting period that Dr. Antevs' work does not touch. It suggests, for instance, where we should look for recessional moraines and how moraines at widely separated points should be correlated. It stimulates more thorough study of the records made in flooded valleys and ponded lakes, with their shifting complicated outlines, and of the upward and downward warpings of the region which accompanied the withdrawal of the ice sheet. It assigns to each deposit its profer date, which, while not as yet connected with later records so as to permit it to be expressed as so many years "B.C.," is nevertheless as accurately referred to a certain point in the glacial period as dates of human history are referred to the beginning of the Christian era.

The larger number of readers, who are not specialists in geology but who are interested in the measurement of time, in prehistoric climate, and in the migrations of plants and animals, will see in these geochronological studies a key which, if properly used in other regions, may settle, better than any other means yet found, the question whether ice sheets on different continents were contemporaneous or not. The attitude of Dr. Antevs 
toward that end is hopeful yet cautious. He sees the solution in a thorough reconstruction of a standard line of observations in each place, through which to measure and identify the long periods of climatic change.

The attention which Dr. Antevs has given in the field to the collecting of additional material to check up his correlations and the care with which he has measured his sections, plotted his curves, compared, corrected, and finally combined these curves so as to work out one "normal series" to express continuous climatic variations of more than 4,000 years will be apparent to anyone who examines his data. His patient scientific treatment of the problem will be fully appreciated, however, by those who put these methods to practice and make measurements and graphs of their own. It is a kind of study that will be most illuminating as it comes to be associated with other methods already in use.

J. IV. GoLDTHWAIT

Dartmouth College, Hanover, N. H. 


\section{INTRODUCTION}

In all history a knowledge of exact time is vital. Chronology is the thread on which events are tied like pearls on a string.

The history of the earth was a history without absolute time, without dates, until Gerard De Geer, forty years ago, found a way which enabled him and Ragnar Lidén to work out a chronology of the last I3,500 years. De Geer's and Lidén's time scale has the year as its unit, and is exact. It is based on annual layers in clay and silt, varves, ${ }^{1}$ very much resembling annual rings of trees. The clay was deposited in lakes in front of the receding edge of the ice sheet, and in fiords in northern Sweden after the ice had disappeared. Except for the last few hundred years, this time scale comprises the whole time since the land ice uncovered southernmost Sweden. The retreat of the ice from southern Sweden to Ragunda, 270 miles north-northwest of Stockholm, took about 5,000 years; and the time that has elapsed since then is found by Lidén to be about 8,500 years. Accordingly, the uncovering of southernmost Sweden began about 13,500 years ago.

During I92I the writer, who had come to America as a member of Baron De Geer's party in 1920, began to work out a chronology of North America in late glacial time ${ }^{2}$ and to that end studied the recession of the last ice sheet in New England and New York State. The present paper is based upon field work carried on during five and a half months and chiefly

1 "The Swedish word varv, subst. (old spelling: hvarf), means as well a circle as a periodical iteration of layers. An international term for the last sense being wanted, it seems suitable to use the transcription varve, pl. -s., in English and

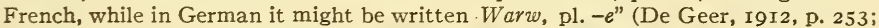
I9I2a, p. 458; for publications cited see List of References at the end of the volume).

2 Post-glacial time, according to the Swedish chronology, begins the year after the bisection of the shrinking ice sheet at Ragunda in northern Sweden. The term "late glacial" refers to the time occupied by the recession of the last land ice up to the event mentioned. Accordingly, in this paper the time occupied by the ice retreat in New England will be called late glacial. 
comprises investigations in the Connecticut Valley from Hartford, Conn., to St. Johnsbury, Vt., and in the Merrimac Valley around Concord, N. H. Field work lasting two months was carried on during the same season in the Hudson and Champlain Valleys and north of St. Johnsbury, but little use is made here of the material collected outside New England. While a chronology of the ice retreat from Hartford to St. Johnsbury has been obtained, this is not connected with present time; and so the question, How long ago? cannot be answered.

No time and trouble have been spared to make the normal curve, which has been compiled from the original measurements, as accurate as possible with respect to both number and thickness of the varves so that it may form a reliable framework for future detailed studies. It is in the extraordinary possibilities of the geochronological studies for accuracy and for detail, as well as in their wide bearing not only on geology but also on other fields of science, particularly geography, climatology, and archeology, that their scientific value and great importance are to be found.

The field work was carried out on a scholarship from the Sverige Amerika Stiftelsen in Stockholm and a special grant from the National Research Council in Washington, and with private means.

The successful completion of this field work and the working up of this memoir are principally due to the kind interest of Professor J. W. Goldthwait of Dartmouth College; Professor Edward B. Mathews of Johns Hopkins University; Mr. Robert IV. Sayles, curator of the Geological Museum of Harvard University; and the American Geographical Society of New York. Professor Goldthwait has ever since our first meeting aided me in word and deed. He has participated in the field work, and he has compiled the map (Pl. VI), which has made it possible to correlate the history of New England with that of the Great Lakes. During the writing of the memoir, at Dartmouth, his advice and help have been of the greatest value. He has also bestowed much labor on its form. Professor Mathews, 
as chairman of the Division of Geology and Geography of the National Research Council, has done much to raise funds for the field work and to interest geological surveys in the northern states. Mr. Sayles has kindly supported the preparation and printing of the illustrations. The American Geographical Society put me in a position to work up my material into this form and has attended to its publication. 



\section{CHAPTER I}

\section{VARVE CLAY, AND THE METHOD OF INVESTIGATION}

\section{Formation of Varve Clay}

In the glaciated areas most of the soils were formed during the disappearance of the last ice sheets. Part of the water from the melting glacier, working down through fissures in the ice, sought its way down to the ground. Here it formed a river and dug a tunnel in the lower part of the ice. Under hydrostatic pressure and with tremendous velocity the river rushed toward the ice edge, carrying with it big boulders, stones, gravel, sand, and mud. When it reached the ice border the pressure gave out, and the transporting power was reduced to a trifle. Boulders and gravel, consequently, were unloaded at the mouth of the tunnel and just beyond it, forming eskers and outwash. The annual deposition of coarse material was often very considerable. If the glacial river discharged into standing water, coarse sand was deposited in the direction of the current for some hundred yards from the ice edge, while silt could be transported considerable distances and fine clay carried more than fifty miles. ${ }^{1}$

In North America large areas which now form fertile clay lands were covered by water at the disappearance of the ice.

\footnotetext{
${ }^{1} \mathrm{I}$ mile $=5,280$ feet $=I .6093$ kilometers. $\quad$ I kilometer $=0.62 \mathrm{I} 4$ mile.

I yard $=3$ feet $=0.9$ I 5 meter.

I foot $=$ I 2 inches $=30.48$ centimeters.

I inch $=2.54$ centimeters.

I meter $=$ I.I yard $=3.28$ feet $=$ 39.37 inches.

I centimeter $=0.3937$ inch.
}

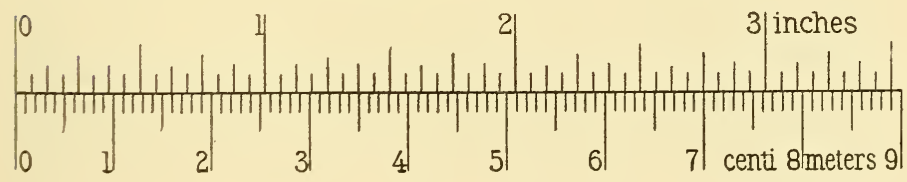




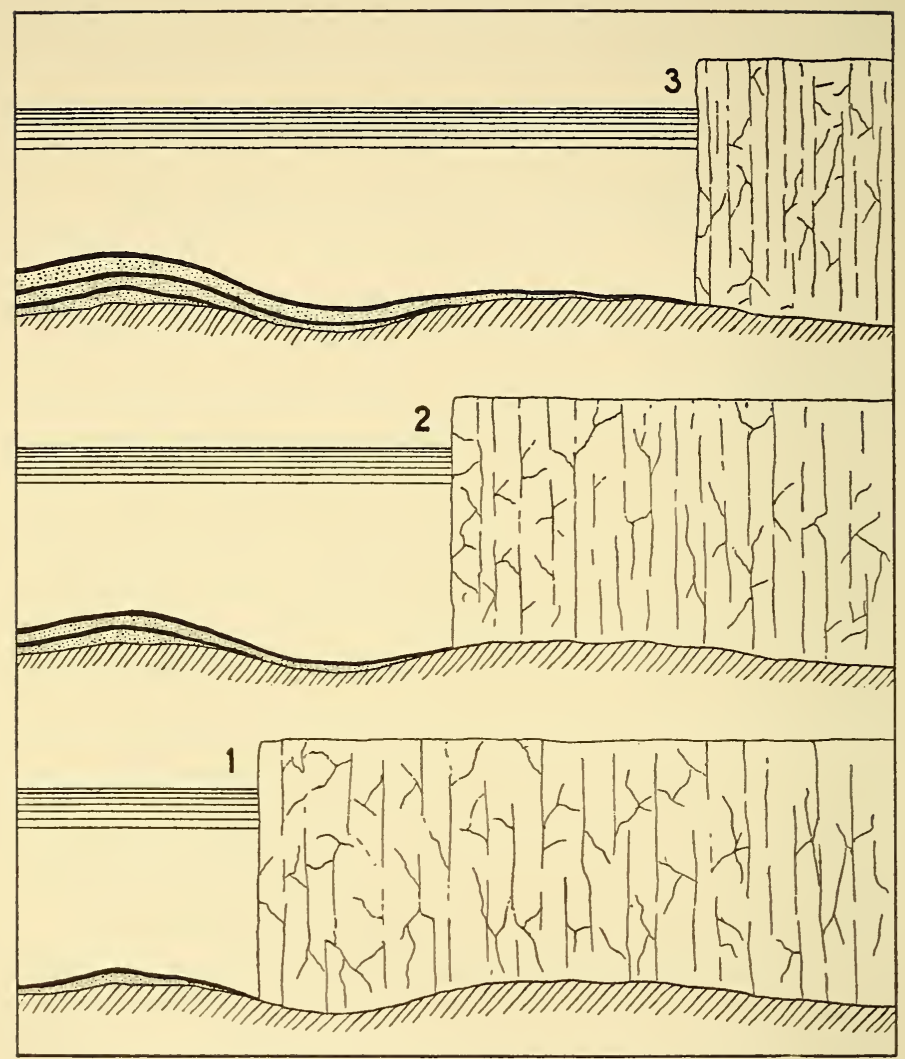

FIG. I-Figure showing manner of deposition of varve clay in fresh water off the receding ice front during three successive years.

Some lowlands were covered, because the land stood lower than it does today, and others were occupied by lakes which were ponded by the ice or by a different inclination of the land. If the glacial river flowed into fresh or slightly salt water, the cold melting water followed the bottom on account of its high specific gravity. The silt and part of the clay dropped to the 
bottom rather soon, but for the most part the finest particles remained suspended for a long time, and settled during the late fall and winter. Consequently, at first silt and coarse clay, then finer and finer clay, were deposited on the lake bottom during a year. The silty part, however, contains a considerable quantity of rather fine particles, which evidently were pulled down by those of greater size (Odén, 1920, p. 339). ${ }^{2}$ Accordingly, the sediments of the year became clearly separated from those of the preceding year. These annual layers are the layers called raries. Clays derived from fine-grained slates or deposited during a time of very little melting and slow current, however, are sometimes practically homogeneous, because even those parts deposited during the summer are greasy. ${ }^{3}$

If, on the contrary, the glacial river discharged into salt or strongly brackish water, as was the case on the Swedish west coast and on the Atlantic coast north of Boston, the ice water rose to the surface because of its lower specific gravity. On account of the salinity even the finest material settled rather soon; and on the sea bottom a more or less homogeneous clay was deposited, a clay in which large grains are mixed with the very finest. It follows that marine clays show no varves.

\section{Method of Investigation}

That the distinct period of time recorded by each layer is the year was suggested, as it seems independently, by several American and Swedish geologists, by Alfred Smith in 1832 (p. 229), Edward Hitchcock in I84I (p. 359), De Geer in I882, Emerson in 1887 (p. 404), Upham in 1888 (p. I32), and Taylor

\footnotetext{
2 Publications are cited thus throughout this work. For full titles see List of References at the end of the volume.

${ }^{3}$ Deposition of glacial varve clay evidently ceased when the land ice had disappeared. In the fiords in northern Sweden, however, deposition of another kind of annually laminated clay followed. This clay, on which the post-glacial chronology is based, is silty and very thinly laminated and shows only faint difference between the two zones which mark the year. The upper dark gray zone, the equivalent of the winter layer in the glacial varve clay, is essentially deposited in connection with the flood of the rivers during the melting of the snow in spring (Lidén, I9I I, p. 273).
} 
in 1894 (p. 288). All of them used this peculiarity as a means for determining the time occupied by the formation of certain clay deposits, but De Geer (I884, I885) alone went farther and found a way to make it the basis for a chronology of the closing stage of the Ice Age. His method is the following.

Since the varves were deposited in front of the receding ice edge, they cover each other like shingles on a roof (Fig. I). Since, also, their thickness varied from year to year and stood in direct relation to the amount of annual melting, which in its turn was chiefly determined by the summer temperature (see p. 85), it is possible to recognize the varves from widely separated localities, provided they lie within a climatologically uniform area. Furthermore, it is possible to determine the rate of the retreat of the ice. To this end exposures in clay pits, bluffs, or special excavations (Fig. 2) are smcothed with spade and brick trowel, and the series of varves are measured from the bottom, if possible, by marking the varve limits carefully on narrow strips of strong paper (Fig. 3). The field measurements are transformed into curves or graphs on paper ruled with lines spaced exactly five millimeters apart, since experience has proved that to be the best. The thickness of the lowest varve is set off on the first vertical line, the second varve on the next line to the right of the former, and so on, and the points marking the thickness of the varres are connected (Fig. 4). ${ }^{4}$ The graph thus secured is compared with one from another locality by moving the two until they match, which, as already explained, they do if they have a series of varves in common. If the bottom varve at one locality is found to correspond to varve number 37 at a more southerly locality, the ice border evidently withdrew over this place 36 years earlier than over the former place.

If the varves are very thin or for some other reason difficult

"De Geer, in order to emphasize the stratigraphy, originally plotted the varves on a series of horizontal lines, beginning with the lowest line and measuring in from the left edge of the paper. When it proved inconvenient to compare the graphs in that position, he turned them $90^{\circ}$ but kept the sequence of the varves; so that on his graphs the first or lowest varve is to the right. 


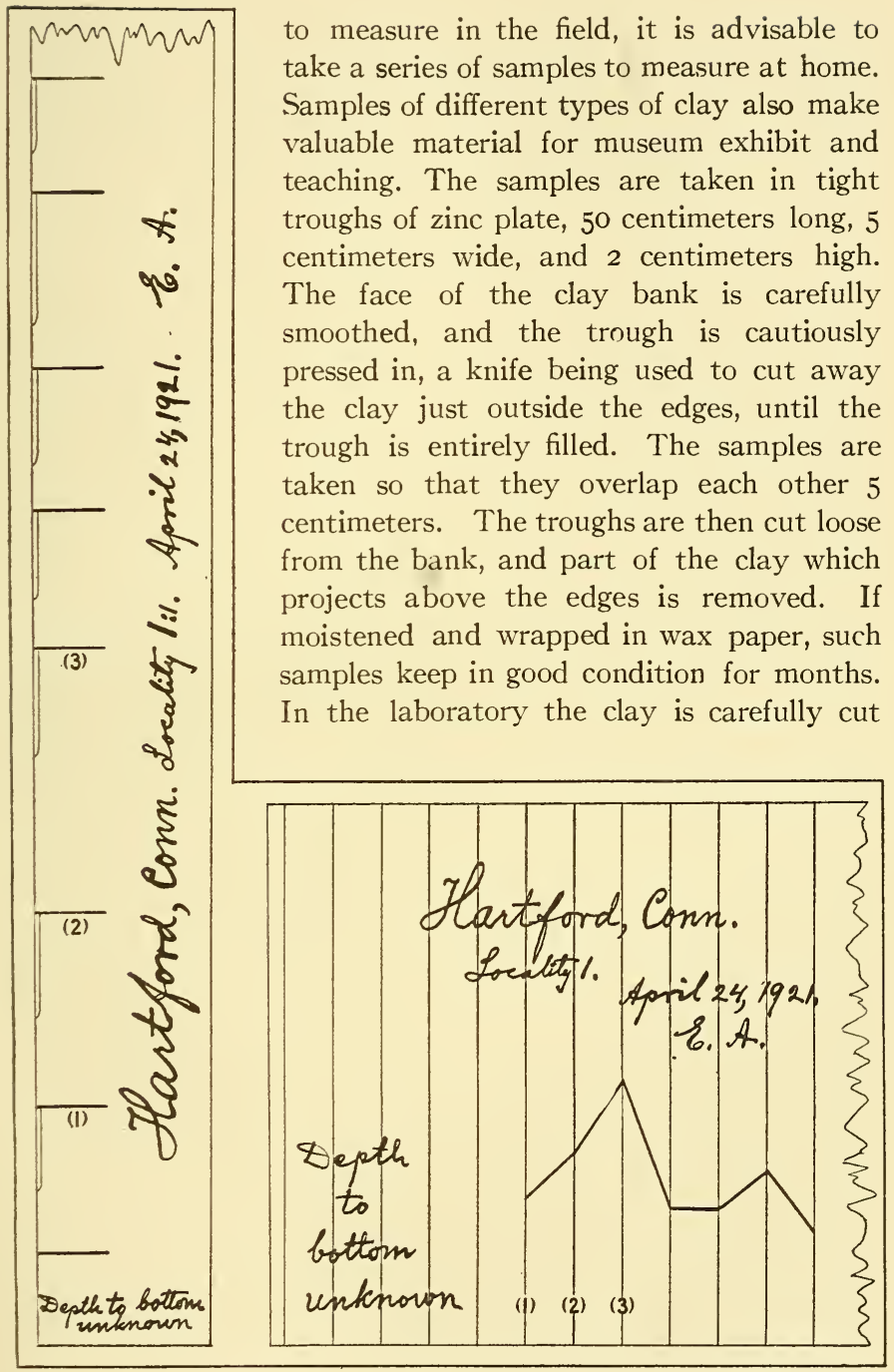

Fig. 4-Sample of measurement made in the field and curve constructed from it in the office. Actual scale. 
down to the edges of the trough. If the clay has dried, it must be gradually moistened and brought back to its natural consistency before it is cut. It is then treated with glycerine as fast as the water evaporates. When all the water is replaced the clay retains its natural appearance unchanged. 


\section{CHAPTER II}

\section{CONDITIONS IN NEIV ENGLAND DURING THE DEPOSITION OF THE VARVE CLAY}

\section{Higher Elevation of Southern New England in Late Glacial Time}

While the last ice sheet was disappearing, southern New England had a higher position than now. This is proved by the occurrence of excellent varve clays at New Haven, Conn., more than 25 feet below sea level, and at Hackensack, N. J., down to more than 15 feet. The clays were deposited in entirely fresh water, in lakes, not in bays of the sea. Varve clays, to be sure, were formed in the sea close to the mouth of a glacial river; but, as the ice edge retired from the place and the amount of melting water diluting the sea water grew less, homogeneous clays were deposited. Varve clays also were deposited in long bays where the water was brackish. In both cases, however, the varves were indistinct, differing considerably from those deposited in fresh water. These facts, as already explained, are well known from studies in Sweden. In the marine area of southeastern New Hampshire the clays are found to be homogeneous. If the sea had covered Hackensack and New Haven in late glacial time, probably about ten varves at the bottom of the clays might have been distinguishable, while the rest of the clay would have been homogeneous.

Accordingly the terminal moraine south of New York City must have been continuous where it now is broken between Perth Amboy and Staten Island by Arthur Kill and between Staten Island and Long Island by the Hudson, at the Narrows. Peet (1904, p. 64I) and Salisbury (1908) discuss the subject and hold forth this as an alternative. Arthur Kill, near its southern end, now is 46 feet deep, and the Narrows reach a depth of II6 feet. Both of them have no doubt been silted up in post-glacial time. 


\section{LoNg IsLand Sound a Lake}

The absence of a barrier off the clay marshes at New Haven seems to show that Long Island Sound in late glacial time was separated from the sea and held a lake. The ponding of a lake with a level of about 40 feet (Dana, I870, p. 66) above present sea level at New Haven evidently signifies that the threshold separating the basin from the sea stood at the same altitude. The sill at the present time between Long Island and Fisher's Island, just southwest of Fisher's Island, rises to within 210 feet of the surface of the sea. To what extent the original, late glacial threshold has been cut deeper cannot be said, but 50 to 60 feet seem likely, judging from the chart. The original sill, then, should now lie at a depth of about I $_{5}$ o feet, and the level of the glacial lake should incline from 40 feet above sea level at New Haven to about 150 feet below it on the threshold. The distance from New Haven straight south to the shore of Long Island, which lies in about the same relation to New Haven as does the threshold, is twenty-three miles. The inclination under these conditions should be about 8 feet to the mile.

\section{Rising of Peripheral Land Following on Recession of Ice, Axd Subsequent Sinking}

At New Haven the writer measured 200 varres and at Hackensack 400 , the measured horizons only representing parts of the clay beds. At Hackensack there are surely more than I,000 varves, probably many more. The existence of the barrier of the lakes for so long a time indicates that the region, at the release of the ice, did not stand in its highest position but took it when the ice front was farther away. As the land rose the barriers were cut down. Since little erosion may have occurred below the level of the sea, eastern Long Island may have reached a level about 185 feet higher than the present. The conditions in southern New England were much the same as in the Baltic region in late glacial time (Antevs, 1922). At the release of the 
ice the region south of the Baltic stood higher than now, while Fenno-Scandia was submerged. The evidence collected is believed to indicate that the magma was pressed ou $i$ from under the center of the ice sheet, causing the peripheral regions to rise. As the ice melted and the pressure decreased, the magma regained its lost ground, and so the receding ice edge was followed by the crest of a wave of elevation. When the crest passed northward, the peripheral region sank until equilibrium was regained. Whether the sinking of the southern New England region was interrupted by oscillations or not is unknown.

Physiographic evidences for an elevation of the lower Hudson district in late glacial time were presented long ago by Woodworth (1905a, p. 229; see also Barrell, 1915, p. 15). The opinion, advanced especially by Fairchild (1914, 1919), that southern New England and New York were submerged at this time does not seem to be supported by any facts.

The district south of Boston, when uncovered, seems to have had the same elevation as now, while the land north of it was depressed beneath the sea and with increasing amount towards the northwest (PI. VI).

\section{Formation of Lakes at Ice Front; Their Sediments the Records Here Studied}

Because of this northward inclination of the land, chains of long narrow lakes were ponded off the receding ice front. By some geologists these have been regarded as bays of the sea. In recent years Goldthwait has undertaken to revise the water levels in the Connecticut and Merrimac Valleys by detailed study. The exact position of the extinct water planes is not yet known, and so only the general outlines of the lakes after Loughlin (1905), Emerson (1898), and C. H. Hitchcock (1878) are shown in Figures 5-13.

Glacial rivers loaded with material discharged into the lakes, and each year a varve of clay or silt was deposited all over the lake bottom. The deposition, if undisturbed, proceeded until 
the lakes were filled up with sediments, which required a considerable length of time, since most of them were very deep. The lake at Woodsville, N. H., lasted more than I,600 years, as recorded by the very thin varves at locality 73 .

As northern New England rose and the southern part sank, and as the rivers cut down the barriers at the southern ends of the lakes, the remnants of them were drained. While the warping of the land proceeded, the rivers began to cut through the lake beds and to expose the sediments. These sections of varve clay are the records studied. 


\section{CHAPTER III}

\section{DESCRIPTION OF THE SECTIONS AT THE LOCALITIES STUDIED}

In the following a description is given of the sections at the localities studied. Their locations are indicated on the series of maps, as follows: localities I-6, Fig. $5 ; 7-25$, Fig. 6; 26-28, Fig. 7 ; 29-34, Fig. 8; 35-43, Fig. 9; 44-60, Fig. I3; 61-67, Fig. I0; $68-73$, Fig. II; 74-9I, Fig. I2. The layers in the sections are enumerated from the top downward.

\section{Localities in the Connecticut Valley}

I. - $3 \frac{1}{4}$ miles SSW of Hartford (railroad station), Conn., Charter Oak Park, Park Brickyard on the eastern side of the railroad. Close to the railroad a hollow was dug down to a depth of 15 feet below the bottom of the clay pit.

5 feet weathered varve clay.

Gray brown clay with thin reddish zones, varves $300 \mathrm{I}-3454 .^{1}$ Lamination very good. Small disturbance at about varve 3240 .

8 inches slidden zone.

Silt to quicksand, 22 varves. Average thickness of varves 2 inches.

Io inches slidden zone.

Silt to quicksand, 27 varves. Average thickness of varves $I / 2$ inches.

Depth to substratum unknown. In the vicinity the thickness of the clay is by borings found to be about roo feet.

Series measured: $3001-3200,3001-3167,3055^{-3346,3115-~}$ 3207 , 31 $55-3206,317$ I-3346, 3250-3454.

${ }^{1}$ For numbering of the varves see page 49. 
2.-300 yards $\mathrm{W}$ of locality $\mathrm{I}$, brickyard $\mathrm{W}$ of the railroad.

2 feet unlaminated sand.

3 feet weathered varve clay.

Gray brown clay with good lamination.

Depth to bottom considerable.

Series measured: $3467-3866,3478-3669,3590-3781$.

3.- I I 2 miles NNE of Hartford, Windsor Ave. and Kensington

St., Nevel's Brickyard.

3-5 feet fine, unlaminated sand.

3-4 feet clay, often with wavy varves, deposited in too shallow water. Some slidden zones. Not connected with the normal curve.

$21 / 2-4$ feet slidden, homogeneous clay.

Gray-brown clay with good lamination, though with some slidden zones.

Depth to bottom unknown.

Series measured: 3023-3068, 3172-3264, 3342-3385, $3462-3595,3564-37$ I $3,3605-3641,3796-3836$.

4. - $3 \frac{1}{2}$ miles NNE of Hartford, brickyard at Wilson.

The clay is covered by 3 feet of sand. The topmost 7 feet of it are disturbed. The color is gray-brown with thin red zones. Lamination is good. Depth to bottom is unknow'n. but no doubt great.

Series measured: 3094-3261, 3462-3501, 3508-3559.

5. -5 miles NE of Hartford, South Windsor, brickyard on Podunk River and the railroad.

The clay is covered by 7 feet of sand. It is gray-brown. The lamination is particularly good. Depth to bottom is unknown. At the railroad bridge the clay is said to be more than 90 feet thick.

Series measured: $3173-3871$. 
6. -7 miles NE of Hartford, East Windsor Hill, brickyard on Stoughton's Brook and the railroad.

The clay is covered by 7 feet of sand. The lamination is good.

The depth to the bottom of the clay is no doubt considerable.

Series measured: $3341-3616,3565-3731,3681-3854$.

7.-23/4 miles SE of Springfield (railroad station), Mass., Forest Park, brickyard on Pecowsic Brook.

5 feet unlaminated sand.

I3 feet varve sand, not measured.

Silt, varves $3623-3766$. Varves in many cases sandy and valueless; probably deposited in too strong current.

Light-gray silt with good varves.

Depth to bottom unknown.

Series measured: $345^{0-3623}, 3459-3840,3543-3590$, $(3623-3766)^{2}$.

8. $-3 / 4$ mile $N$ of Springfield, brickyard on Carew Street.

6-I2 feet unlaminated sand.

8 feet varve sand, not measured.

Sandy varve silt, often with layers of quicksand. Winter layers thin, dark brown.

Depth to bottom unknown.

Series measured: 3758-3930, 3880-3930, (393I-4013, 393I-40I4, 4027-4108).

9.-Chicopee, Mass., brickyard at the southern edge of the city.

Two sections were measured:

A.-An abandoned clay pit S of the brickyard, on the highway to Springfield.

Io feet unlaminated sand.

I 2 feet sandy varve silt with lenses of sand, not measured.

Sandy silt, varves $3782-3870$, not used in the construction of the curve.

Depth to bottom unknown.

${ }^{2}$ Parentheses indicate that the varves have been used only in correcting, not in constructing the normal curve. 


\section{9.--Continued}

B.-Clay pit E of the yard.

4 feet unlaminated sand.

Varve clay containing a few sandy zones and becoming sandy towards the bottom of the section.

Depth to substratum unknown.

Series measured: 3798-4120, 4006-4053.

I0.- I $3 / 4$ miles $\mathrm{S}$ of Holyoke (railroad station), Mass., Willimansett, Holyoke Brick Co.'s yard on Crowfoot Brook and the rdilroad.

I 2 feet unlaminated sand.

Sandy varve silt with some thin disturbed zones.

Depth to bottom unknown.

Series measured: 393I-4083, 4093-4I54, (4I55-4I8I).

I I.-I mile NNE of Holyoke, South Hadley Falls, Lynch Brickyard, abandoned clay pit SE of the yard.

45 feet sand, mostly, if not all, varve sand. One thin winter layer observed I 2 feet up; all other winter layers seem to have been eroded away during the springs following their deposition.

$4^{1 / 2}$ feet sand, varves $4290-4294$, thickest varve 2 feet.

Varve silt, somewhat sandy. Lamination good.

Depth to bottom unknown.

Series measured: 4156-4264, (4265-4294).

12.- 250 yards $N$ of locality I I.

Varve silt covered by a few sandy varves. Depth to bottom is unknown.

Series measured: 4220-4264, 4224-4264, (4265-4292).

I3. - 500 yards $N$ of locality I I, Lynch Brickyard, pit $N$ of the crossroads.

The clay, which is silty, shows very good lamination. It is covered by 3 feet of sand. Depth to bottom is unknown.

Series measured: 4099-426I. 
I4. - 200 yards N of locality I3, Hampshire Brick Co.'s yard.

A few feet of varve sand.

Varve silt, changing downwards into clay, which finally becomes fat. Lamination very good.

I $1 / 2$ feet slidden clay, probably representing only a few varves. Gravel and cobbles at the bottom of the clay pit. Varve clay is said to occur beneath and to extend to unknown depth.

Series measured: 3903-4256, (4257-4273).

15.-3 miles NNE of Holyoke, South Hadley, ravine on Stony Brook at the southern edge of the village, 200 yards $W^{T}$ of the highway.

More than 20 feet sand.

4 feet disturbed varve clay.

Red-brown clay in thin, typical varves, numbers $4405-4656$.

Silt and sand, varves 4397-4404.

Sand somewhat coarser than quicksand, with varves up to $51 / 2$ feet in thickness, numbers $4357-4396$ (cf. p. 5I).

Silt and quicksand in thick varves, numbers $4296-4356$.

Depth to bottom considerable.

Series measured: 4305-4356, 4305-4356, 44II-4600. (4289-4304, 4357-44IO, 4357-4375, 460I-4656).

16. $-3 / 4$ mile NIV of locality 15 , bluff on Stony Brook.

2 feet till with several o-inch cobbles, probably carried there by an iceberg.

3 feet weathered varve clay.

Clay with good lamination, varves $4405-4630$.

Varve sand down to the level of the brook.

Depth to bottom considerable.

Series measured: 4405-4600, (4387-4404, 460I-4630).

17.- $4^{1 / 2}$ miles $N$ of Westfield, Mass., brickyard on the railroad.

Two sections were measured:

A.- The eastern clay pit.

Silt with winter layers so thin that the varve limits are very difficult to distinguish. The silt is covered by 3 feet of coarse sand. Depth to bottom is unknown.

Series measured: (3780-3885). 


\section{7.-Continued}

B.-The western clay pit.

5 feet coarse sand.

4 feet disturbed silty varve clay.

Clay with good lamination.

Depth to bottom unknown.

Series measured: 3889-3966, 3890-3966, (3967-3988, 3967-3973).

I8. - 4 miles SSIV of Northampton (railroad station), Mass., I mile $\mathrm{E}$ of Easthampton, brickyard on the road and the brook.

Lamination is very fine, but several zones are strongly disturbed. One measurement extends to 5 feet below the brook. Depth to substratum is unknown.

Series measured: 4228-4327, 4254-4324, 4304-4327, $4342-4440,4342-4413,4342-4375,4497-4610,47$ I5-4755, $4766-4845,(4846-4965,4853-5104)$.

19. - I I 2 mile SW of Northampton, brickyard at the southwestern edge of the city, on the railroad and the trolley line to Easthampton.

8 feet varve sand with lenses of sand, not measured.

Silt, sandy near the top since deposited in too shallow water, varves 5243-5490.

Fat clay with very good lamination, though with many slidden zones.

Depth to bottom unknown.

Series measured: 4556-46I8, 457 I-4885, 459I-4620, $4673-4743,4652-4834,4768-4826,4785-48 I_{3}, 4785^{-}$ $48 \mathrm{I} 3,4785-48 \mathrm{i} 3,(5243-5490)$.

20.-II/4 mile IVNW of Northampton, brickyard off Elm Street at the junction of Florence and Bay State roads.

3 feet sand.

2 feet weathered and disturbed varve clay.

I $1 / 2$ feet clay, IIo varves, not connected with the normal curve. 
I3 feet silty clay, homogeneous through disturbance.

4 feet quicksand, slidden at the top, varves 4633 and 4634 (cf. p. 79).

Silty clay, sandy at the top. Lamination good.

Depth to bottom unknown.

Series measured: $4377-4549,455^{6}-45^{85}, 455^{6}-45^{85}$

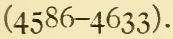

2I. $\mathrm{I} 3 / 4$ miles $N$ of Northampton, brickyard on the railroad at the sharp bend of the Connecticut River.

The clay is covered by 3 feet of sand. The varves are very distinct, but the clay has many and broad disturbed zones. Depth to bottom is no doubt considerable.

Series measured: 46II-4633, 46II-466I, 4703-4772, 4703-4744, 4775-4798, 480 I-4910, 4806-49I I, 4823-4840, $48.32-4910,4870-49024876-4909,5243-5278,5243-5269$, 5396-5479, 5398-5479, $\left(45^{6} 5-45^{8} 5\right)$.

22. $-1 / 3$ mile $N$ of locality $2 \mathrm{I}$, slide on the western side of the big oxbow of the Connecticut River.

The clay is covered by ro feet of sand. It is gray-brown in zolor and well laminated, but many and broad zones are disturbed. About 20 feet above the river level the clay passes into varve sand, which extends to unknown depth,

Series measured: 4617-4683, 4628-4683, 5243-5416, (4569-4594, 4818-4878, 5417-5497).

23.-2 miles ENE of Northampton, I mile S of Hadley, the eastern bank of the Connecticut River at the sharp bend.

The clay is covered by 15 feet of sand. It is fat, gray-blue, well-laminated, though with one or two slidden zones. Measurements extend down to 2 feet below river level. The depth of the clay is unknown.

Series measured: 4845-4877, 4854-4959, 4892-4952, 4892-5046, 4948-5170, 4995-5I I0, 5043-5209, 5I II-5222, 5243-5280, 5244-5290, 5260-5446, 5455-5510. 
24. -2 miles SE of Amherst, Mass., clay pit W of the railroad tracks.

$2 \mathrm{~T} / 2$ feet till.

$21 / 2$ feet crumpled clay.

Io feet excellent varve clay.

I $1 / 2$ feet till.

More than $I \frac{1}{2}$ feet quicksand.

Series measured: 446I-4668, (4450-4460).

As explained on page 79 , the overlying till most probably marks a readvance of the ice edge. Tle lower till may only represent a small readvance during the winter following the deposition of the sand.

25.-A few hundred yards SE of locality 24, clay pit at tho eastern railroad track.

The clay is covered by $2 \frac{T}{2}$ feet of sand. Depth to bottom is unknown.

Series measured: $4537-4588,4617-4685$.

26.-Greenfield, Mass., brickyard at the western edge of the town, off Elm Street.

Typical silty varve clay, although towards the top the winter layers are so thin that some varve limits are difficult to distinguish. Depth to substratum is unknown, but probably not great.

Series measured: 5119-5500, 5128-5203 5220-5256, $533 \mathrm{I}-5365$.

27. - 2 miles $\mathrm{E}$ of Greenfield, old brickyard $\mathrm{E}$ of Montague City, on the highway running eastward.

The silty clay is distinctly laminated. It is covered by ro or more feet of sand. Depth to bottom is unknown.

Series measured: 5254-5456, (52 I I-5253). 
28. -600 yards $\mathrm{N}$ of locality 27 , brickyard between Montague City and Turners Falls.

8 feet unlaminated sand.

8 feet varve sand.

Gray silty clay with several thick sandy varves, most of which may represent drainages. Lamination very good except towards the top, where many of the varves are wavy and the winter layers very thin.

Depth to bottom unknown.

Series measured: 5084-5500 (drainage varves not used in the curve), (5501-5570).

29. - On the Connecticut River $43 / 4$ miles $N$ of the Massachusetts boundary, railroad cut 500 yards NW of Fort Hill station, N. H.

I5 feet gravel and sand.

Gray silt with dark winter layers. Thick varves sandy. Measurement extends down to 4 feet above the rails.

Depth to bottom unknown.

Series measured: $543^{-}{ }^{-5600},\left(560 \mathrm{I}^{-5}{ }^{6} \mathrm{I} 3\right)$.

30.-Keene, N. H., old brickyard at the southern edge of the city, a few hundred yards $\mathrm{E}$ of the railroad bridge across the Ashuelot.

In May, I92I, the clay pits were filled with water so that only a short, partly disturbed section was accessible. The sediments consist of gray silt with very thin winter layers.

Series measured: 5804-5879, (5687-5733).

31. -9 miles NNE of Brattleboro, Vt., brickyard 400 yards W of Putney station.

5 feet sand and silt.

Varve silt, at the very top sandy, varves $6 I_{7} 6-6277$. Winter layers very thin.

Sandy silt with very thin winter layers, varves 6I00-6I 75 .

Thick silty clay with excellent lamination.

Depth to bottom unknown.

Series measured: 5713-6277, 6088-6277, 6094-6179, 6246-6277. 
32. -8 miles $\mathrm{S}$ of Bellows Falls, Vt., 3 miles $\mathrm{N}$ of East Putney station, railroad cut.

I2 feet $\left\{\begin{array}{l}\text { Terrace gravels with cobbles } 4 \text { inches in diameter. } \\ \text { Sand. }\end{array}\right.$

Well-laminated silt. Average thickness of varves 3 inches.

Depth to bottom considerable.

Series measured: (594I-6020).

Sections 32 to 40 have not been used in constructing the normal curve, because the varves, which show good correspondence, are too thick.

33. - 600 yards $N$ of locality $32,21 / 2$ miles $S$ of Grout starion, railroad cut.

Io feet gravel and sand.

Io feet slidden silty clay.

Silty clay. Average thickness of varves 4 inches.

Depth to bottom unknown.

Series measured: $(5869-5893)$.

34. $-61 / 2$ miles $S$ of Bellows Falls, 2 miles $S$ of Grout station. brook ravine 100 yards $W$ of the railroad and the highway.

$I / 2$ feet sand.

3 feet coarse gravel with boulders up to Io inches in diameter.

9 feet sand.

Typical silty varve clay; towards the bottom varve sand. Some disturbed zones near the bottom. Average thickness of varves about $3 \frac{1}{2}$ inches.

Bed rock.

Series measured: (5802?-5828?, 5865-5970).

The number of the bottom layer is about 5797 .

35. - 5 miles SSW of Bellows Falls, I mile SIT of Grout station, bluff on the brook just W of the highway.

I 2 feet gravel, and sand.

Gray silt with excellent lamination. The topmost horizons much disturbed. Average thickness of varves about 3 inches.

The silt continues to unknown depth below the brook. 
Series measured: (6006-6I50, 6006-6087, 6094-6I93, 6094-6I38, 6II4-6I52, 6II7-6I56, 6200-6234, 6240$6250)$.

36. $-21 / 2$ miles $\mathrm{S}$ of Bellows Falls, $3 / 4$ mile $\mathrm{N}$ of Westminster station, slide just $\mathrm{W}$ of the highway and 250 yards $\mathrm{W}$ of the railroad.

The varve silt is covered by I 7 feet of sand. Average thickness of varves $3 \frac{1}{2}$ inches. Depth to bottom is considerable.

Series measured: (6I93-62I4).

37. $-21 / 2$ miles SSW of Bellows Falls, I $1 / 4$ miles WNW of Westminster station, bluff on the northern branch of brook $1 / 2$ mile $W$ of the point where it joins the southern one 250 yards $W$ of the highway.

I 2 feet unlaminated sand.

3 feet varve sand, varves $626 \mathrm{I}-6276$.

Silt, varves $6212-6260$. Average thickness of varves 5 inches. Varve sand with lenses from 50 feet above the brook and downward. Lower part of bluff covered by talus.

Series measured: $(62 \mathrm{I} 2-6276)$.

This section is not used in the construction of the standard curve.

38. -6 miles $N$ of Bellows Falls, Vt., I $1 / 2$ miles SW of Charlestown, N. H., bluff on the western side of the Connecticut River.

3 feet fine unlaminated sand.

$21 / 2$ feet gravel.

5 feet silt to fine sand.

Varve silt, the thickest varves sandy. Lamination good. Average thickness of the varves I foot.

Sediments extend to unknown depth below the river.

Series measured: $(6163-62 \mathrm{I} 8)$. 
39. $-\mathrm{I} / 2$ mile $\mathrm{N}$ of locality 38 , slide in a ravine 100 yards $I V$ of the river.

The distinctly laminated silt is covered by 8 feet of sandy silt. The accessible section begins 25 feet above the river level, the lower part being covered. The average thickness of the varves is somewhat less than a foot.

Series measured: $(6086-6$ I36).

40.-Charlestown, N. H., bluff on the Connecticut River directly IV of the railroad station.

7 feet river gravel.

Varve silt with some disturbed zones. Average thickness of varves 8 to Io inches.

More than 7 feet glacial gravel.

Series measured: $\left(6007-6034,6069-608_{3}\right)$.

Varve 6007 is bottom varve.

41. -5 miles SSIT of Claremont, N. H., bluff on Little Sugar River 600 yards IV of North Charlestown station.

4 feet coarse gravel, in which boulders 4 to 8 inches in diameter constitute half the deposit. Several boulders are a foot in diameter. One block measured I foot 4 inches.

I foot sand.

Discordance.

Varve sand extending to unknown depth below river level. Average thickness of varves Io inches.

Measurements include one series of 50 and another of 30 varves from the same horizon. The series are not connected with the normal curse.

The gravel at the top is probably outwash indicating a readvance of the ice edge (cf. p. 8I).

42. - I/2 mile NNE of locality $8 \mathrm{I}$, sand pit on the highway to Claremont.

Silt with varves on an average 7 inches thick.

Series measured: 25 varves corresponding to the series at locality 41. 
43. - $1 / 2$ mile IVSW of Claremont Junction, N. H., clay pit on the road.

Io feet sand and silt.

Sandy varve silt with very thin winter layers. Average thickness of varves $2 \frac{1}{2}$ to 3 inches. One or two zones disturbed.

Depth to bottom considerable.

One series of 70 and another of Ioo varves measured from the same horizon. The series are not connected with the normal curve.

\section{Localities in the Merrimac Valley}

44. -7 miles SSE of Concord (railroad station), N. H., old brickyard halfway between Suncook and Hookset.

The clay is covered by 5 feet of sand. It contains several disturbed zones. Depth to bottom is unknown.

Series measured: (5764-579r, 5804-5811, 5850-5875).

45. $-4 \frac{1}{2}$ miles SE of Concord, old brickyard on the brook between the Merrimac River and Pembroke.

3 feet weathered clay.

Clayey silt with excellent lamination.

3 to 6 feet down to till, which shows in the brook.

Series measured: $5709-5749$.

46. - 2 miles $S$ of Concord, clay pits 400 to 700 yards $W$ of Bow Junction.

Surface of wash plain.

Io feet sand.

Sandy silt, varves somewhat wavy since deposited in too shallow water, numbers 6308-6352. Winter layers hardly distinguishable.

Excellent clay, varves 577I-6307.

Sand to silt, somewhat slidden. I4 varves of an average thickness of $5 \frac{1}{2}$ inches.

8 to ro feet down to till, which appears in the brook close by. The lowest horizons measured 700 yards $\mathrm{W}$ of Bow Junction, just $\mathrm{N}$ of the highway bridge across the brook.

Series measured: $577 \mathrm{I}-6332,6233-6352,6305-6352$. 
47. -2 miles SE of Concord, bluff on the eastern side of the sharp bend of the Merrimac River.

Io feet sand.

2 feet disturbed varve clay.

Sandy clay, often with lenses of sand, varves 6009-6095.

Very good, silty clay, varves 59I4-6008.

I3 feet talus down to river level. Depth to bottom unknown.

Series measured: (5914-5974, 5980-6095).

The greater part of the curve shows typical variation, but it has not been used in the construction of the normal curve, since the varves are too thick. The same is the case with many other sections in the Merrimac Valley.

48.-I mile SE of Concord, 400 yards $\mathrm{E}$ of the highway bridge across the Merrimac River, just $\mathrm{S}$ of the highway.

The clay is covered by I3 feet of sand. The uppermost 6 feet of the clay are slidden. Depth to bottom is considerable.

Series measured: (6267-6304).

49. $-3 / 4$ mile ESE of Concord, old brickyard on the eastern side of the Merrimac River, at the bend.

The clay is covered by 3 to 6 feet of sand. Several varves are sandy, and the thicknesses are not so good. At the bottom of the pit the varves are thick and sandy, probably indicating inconsiderable depth to substratum. Several zones are slidden.

Series measured: (579I-5830, 5794-5829, 5808-6047, $5839-5872,5883-5937,5948-5987)$.

50.- I mile NE of Concord, bluff on the eastern side of the Merrimac River, 500 yards $N$ of the state highway running from Concord eastward.

Surface of wash plain.

50 feet sand.

Varve sand; 5 varves from 2 inches to 8 feet thick.

I6 feet covered by talus.

At the level of the river varve quicksand; varves 8 inches thick.

Thus far I have not been able to connect this section with the normal curve. 
$51 .-1 / 2$ mile $N$ of locality 50 , Sugar Ball Bluff on the eastern side of the Merrimac River, at the sharp bend.

Surface of wash plain.

30 feet sand.

Varve sand; 5 varves varying from $I \frac{1}{2}$ inches to 8 feet in thickness.

50 feet (varve sand?) covered by talus.

At river level varve silt; Io varves averaging $I \frac{1}{2}$ inches in thickness.

The series is not connected with the normal curve.

52.-7 miles NNW of Concord, $1 / 2$ mile NW of Boyce station, bluff on the eastern side of the Merrimac River.

Surface of wash plain.

60 feet of sand, mostly covered by talus, perhaps partly varve sand.

Varve sand, varves 6232-6243; average thickness I foot.

Silt and quicksand, varves $622 \mathrm{I}-623 \mathrm{I}$; average thickness 3 inches.

Good silty varve clay.

Talus extending I3 feet down to the river level.

Series measured: 6105-6141, 6163-6220, (6142-6162, $622 \mathrm{I}-6243)$.

53. -250 yards NE of locality 52, bluff on the Merrimac River and ravine 75 yards $E$ of the bluff and 75 yards $W$ of the railroad.

Surface of wash plain.

50 feet sand, mixed with some gravel.

Varve sediments; thick varves consisting of sand, thin varves of silt or sandy silt; thickness varying from $\mathrm{I} / 2$ inches to $31 / 2$ feet.

Talus Io feet down to river level.

One series of 45 and another of 38 varves were measured on the same horizon. They are not connected with the normal curve. 
54. - $7 \frac{1}{2}$ miles NNTW of Concord, I mile NW of Penacook station, gravel pit just $\mathrm{W}$ of the railroad, 400 yards $\mathrm{S}$ of the bend of the Merrimac River which lies close to the railroad.

$21 / 2$ feet sand.

I $1 / 2$ feet varve sand, disturbed.

2 feet sandy varve silt, partly disturbed.

Silty clay, varves 5942-6I 77. Two zones disturbed.

3 inches slidden zone.

Varve sand, I5 varves.

Depth to bottom probably inconsiderable.

Series measured: 5942-5985, 5995-6124, 6I44-6I77, $(6 \mathrm{I}-8-620 \mathrm{I})$.

55 . -250 yards $\mathrm{N}$ of locality 54 , bluff on the western side of the Merrimac River, I 50 yards $\mathrm{S}$ of the bend of the river.

The clay is covered by Io feet of sand and gravel. The lamination is excellent. The clay continues to unknown depth below the river level.

Series measured: 6004-6I 77,6 I84-6220, (6I78-6I 83 , 622I-6234).

56. - 350 yards NE of locality 55 , bluff on the eastern side of the Merrimac River.

The well-laminated, gray clay is covered by 5 feet of fine gravel. It continues to unknown depth below the river.

Series measured: $5987-6220,(5937-5986,6221-6247)$.

57 - $1 / 3$ mile NNE of locality 56 , bluff on the eastern side of the Merrimac River. Three sections were measured:

A.

Surface of wash plain.

25 feet sand, towards the north much thicker, as the underlying varve sand dips that way.

Varve sand, 20 varves, from 6 inches to 7 feet in thickness. 40 feet talus down to the river level.

The varve series corresponds to the lower part of section 53. It is not connected with the normal curve. 
B.

Surface of wash plain.

About roo feet sediments, not exposed (sand?).

Varve silt and sand, varves 6306-632I. Thicknesses varying from 3 inches to $I / 2$ feet. The lowest varve measured 5 feet above the river.

Series measured: (6306-632I).

C.

Surface of wash plain.

Ioo feet sediments, not exposed (sand ?).

Varve silt, varves $6267-6303$. Average thickness $2 \frac{1}{2}$ inches. 3 feet talus down to river level.

Series measured: $(6267-6303)$.

58. - Io miles NNW of Concord, clay pit at the schoolhouse $1 / 2$ mile NIV of Canterbury station.

Cut in the upper part of silty sediments. Thickness of varves varying from $I$ to 9 inches.

Series measured: $(6265-6312)$.

59.-I I miles NNW of Concord, 2 miles $\mathrm{N}$ of Boscawen, railroad cut.

3 feet sand.

$2 \mathrm{I} / 2$ feet sandy varve silt.

Characteristic clay, somewhat silty, varves $6003-6232$.

Varve sand and silt, varves 5989-6004. Varve 5989 more than $2 \frac{1}{2}$ feet thick, the others varying from 3 to Io inches. 25 feet talus ending at the stony bottom of a brook.

Series measured: 6025-6232, (5989-6024, 6233-6255).

60.-Franklin, N. H., clay pit at the northwestern edge of the village, near the underpass of the Mascoma road.

3 feet varve silt with lenses, not measured.

Silt. The topmost varve 3 feet, the lowest I foot 2 inches and the rest from I inch to I foot in thickness.

Depth to bottom unknown.

Series measured: (6162-6185). 


\section{Localities in the Connecticut Valley (Continued)}

6I.- 5 miles S of Windsor, Vt., bluff on the brook S of Ascutneyville, between the highway and the Connecticut River.

Plain of sedimentation.

4 feet gravel.

2 feet sand and silt.

Varve sediments, silt in the upper half, sand in the lower half. 25 feet glacial gravel.

Bed rock.

Series measured: 660I-6662, (6608-6638).

In the same bluff, a little to the east, the section is essentially different because of disturbances and downslidden horizons.

Number 660I is bottom varve.

62.-3 miles NW of Claremont, N. H., bluff on the highway, just $W$ of the junction of the Sugar River, the railroad, and the highway.

The material is silty. The thickness of the varves varies from

6 inches to $2 \frac{1}{2}$ feet. Depth of the deposit is unknown.

Series measured: (66I3-663I).

63. $-31 / 2$ miles NTW of Claremont, $3 / 4$ mile $N$ of the railroad bridge across the Sugar River, where the railroad crosses Walter Brook.

Several measurements were carried out in slides in the deep brook ravine as far as $1 / 2$ mile NNE of the railroad as well as in the railroad banks $\mathrm{N}$ and $\mathrm{S}$ of the brook. 600 yards NNE of the railroad the profile was like this:

Plain of sedimentation.

I 5 feet sand.

Varve silt to sand with thin winter layers, varves 6806-7073.

Varve clay to silt with very good lamination, varves $6642-$ 6805.

Varve silt, somewhat sandy, with several slidden zones. Thickness of varves from 2 inches to 2 feet. About 30 varves measured but not connected with the normal curve.

6 feet talus down to the brook. Depth to substratum probably inconsiderable. 
Series measured: 6642-6662, 6643-6666, 6647-6713, 6648-6658, 6680-6706, 6690-6805, 67 14-6823, 6726-6823, $68 \mathrm{I}$ I-6823, 6858-698 I, 6858-6922, 6858-6898, 6858-687 I, 6894-7073, 6930-6980.

64.-I mile SSE of Westboro, N. H., ravine on the southern side of the Mascoma River, $\mathrm{S}$ of the first railroad bridge across the river.

Plain of sedimentation.

4 feet fine sand.

Typical varve clay.

80 to Ioo feet till down to the river.

Series measured: 6750-6802, (6734, bottom varve -6749).

65. - I mile SE of Westboro, cut on the road I50 yards $\mathrm{NE}$ of the new bridge across the Mascoma River and the railroad.

The clay shows good lamination. Depth to bottom is unknown.

Series measured: $(6760-6801)$.

66. $-3 / 4$ mile $N$ of White River Junction, Vt., ravine just $W$ of the railroad.

The clay shows rather good lamination. It is covered by 4 feet of sand. Below the measured series the varves, which are slidden, become thick and silty. Depth to substratum is more than 30 feet.

Series measured: $6783-6888$.

$67 .-3 / 4$ mile SSE of Hanover, N. H., bluff on Mink Brook.

25 feet sand and silt. Varve limits hardly distinguishable.

Varves 6806-7040, silty, often sandy and with lenses of sand. Varve limits often very difficult to distinguish. Thicknesses varying greatly, but on the average about 2 inches.

Varves $6760-6805$, silty, distinct. Thickness varying from I to 5 inches.

Exposed to the level of the brook. Depth to bottom unknown.

Series measured: (about 6760 to about 7040; only varves 6806-6862 have been used for control of the number). 
68.-I I $1 / 2$ miles NNE of Hanover, 300 yards NE of Northboro station, clay pit on the eastern side of the Connecticut River.

About 10 feet sand and silt.

About to feet clay with very thin varves becoming sandy upwards, not measured.

Varves 6867-7021. Average thickness about $1 / 3$ inch. The thicknesses not characteristic, and the profile of little value.

Disturbed zone: silt with rests of thick varves.

Depth to substratum unknown.

Series measured: $(686 ;-702 \mathrm{I})$.

69. - I I $/ 4$ miles $E$ of locality 68 , bluff on Clay Brook.

Silt.

I 5 feet clay with very thin varves, not measured.

Varves $6857-6957$, on the average $1 / 2$ to $3 / 4$ inch thick. Thicknesses not characteristic.

Disturbed quicksand.

Depth to bottom unknown.

Series measured: $(6857-6957)$.

7o.- I I miles SSIT of Woodsville, N. H., I mile NE of Bradford, $V t$., bluff on the eastern side of the Connecticut River, back of a cemetery.

Sand.

Varve clay. High and fine exposure, not measured on account of lack of time.

Varve clay, measured down to river level, from varve $704 \mathrm{I}$ and upward exceedingly fat. Lamination good. Varve 69oI, if not bottom varve, is practically so. Varves 690I-6903 consist of quicksand. Varve 690I is more than 2 feet, varve $690261 / 4$ inches, and 6903 10I/2 inches thick.

Series measured: 690I-7II2.

7I.-IO miles SSIT of Woodsville, 3 miles SIT of Haverhill station, ravine on the western side of the road, close to the bend of the Connecticut River, just $\mathrm{N}$ of a farmhouse.

High section with some slidden zones. On account of lack of time only a few bottom varves were measured. The clay rests on till. Varre 6904 is bottom varve.

Series measured: (6904-6912, 6027-6936). 
72 . -7 miles $\mathrm{S}$ of Woodsville, $3 / 4$ mile $\mathrm{N}$ of Haverhill station, ravine on the western side of the highway.

The upper 20 feet of the section covered by turf. The clay is very fat and with many disturbed zones. The underlying till was reached, but the bottom varves are missing because of landslide.

Series measured: 7009-7048, (7049-7106, 7130-7174, 7199-7228, 7236-7268, 7274-7304).

73. -7 miles $\mathrm{S}$ of Wells River, Vt., I mile $\mathrm{N}$ of Conicut station, brook ravine Ioo yards $\mathrm{W}$ of the railroad, where the bend of the Connecticut River comes close to the railroad.

Plain of sedimentation.

20 feet varve sand, about 30 varves.

Io feet varve clay, 275 varves.

Io $1 / 2$ feet varve clay, 900 varves.

Varve clay with good lamination but with some disturbed zones, measured.

Level of the brook. Depth to substratum unknown.

Series measured: 6990-7004, 7008-7087, 7199-7316.

This profile shows that the glacial lake was in existence for at least 1,600 years.

74. -6 miles $\mathrm{S}$ of Wells River, one clay pit I mile S of Newbury station $\mathrm{I} 50$ yards $W$ of the railroad and another 300 yards farther $\mathrm{S}$ just west of the tracks.

Small sections in partly disturbed clay. Varves at different horizons slidden away.

Series measured: 7008-7048, 7008-7042, (7049-7066, 7073-7 II5).

75. $-4 \frac{1}{3}$ miles $\mathrm{S}$ of Woodsville, N. H., bluffs on the brook 300 yards $\mathrm{S}$ and $\mathrm{IW}$ of Blackmount station.

The clay is underlain by till. The sections are of little value, since several zones are slidden.

Series measured: 6930, bottom varve $-6941,6967-7048$, 6967-6985, 7008-7029, 7009-7048, (7035-7088, 70497092, 7 147-7201). 
76. -2 miles $W$ of Wells River, Vt., brickyard on the brook discharging into the Wells River. De Geer's (I92I) locality "Wells River." De Geer's profile was measured on a series of samples taken by $\mathrm{R}$. Lidén.

25 feet sand.

Io feet varve sand to silt. Varves on the average I inch thick. Varve limits very difficult to distinguish.

Varve clay, varves 6970-7500. Lamination poorly developed.

Probably not far down to bottom, since till appears in the brook close to the section.

Series measured: (6970-7500).

Since the clay was very difficult to measure, and my measurement shows little agreement with the others from the region, this section has not been used for the correction or the construction of the normal curve.

77. -Wells River, 300 yards $N$ of the station, cut on the western side of the highway.

7 feet silt and sand, varves about I foot thick.

7 feet silty clay, varves too thin to be measured or counted. 3 feet silty clay, often with sandy layers, about 200 varves.

Fat blue-gray varve clay with one or two folded zones, varves 7155-7290. Average thickness about $1 / 2$ inch. Lamination good.

I 2 feet talus.

Sand. Depth to bottom of sediments unknown.

Series measured: (7155-7290).

78.-Woodsville, N. H., brickyard $1 / 2$ mile $N$ of the station. De Geer's (I92I) locality "Woodsville". De Geer's section measured by R. Lidén.

The clay pits are situated at the foot of a hill. The appearance of the profiles, in 1916, has been described in detail by Sayles (1919, p. I8). In I921 the exposures were not quite so good. 
A. - The western clay pit.

The clay rests on till. The I50 lowest varves have slidden away. Many zones are disturbed. The clay, in some zones, is exceedingly fat and has been squeezed, so that the thicknesses of many varves are unreliable. Consequently my measurements are valueless.

Series measured: (7100-about 7300).

Beside this a series of 150 varves, containing 3 thick slidden zones; these varves not connected with the standard curve.

B.-The eastern clay pit.

The clay is so disturbed that no part of my measurement can be connected with the normal curve. It contains several beds of till which may have slidden down from the hill that rises just behind the section, or may have been brought there by icebergs.

79. - I mile $\mathrm{N}$ of Woodsville, ravine $\mathrm{E}$ of the road. The lowest varves were measured 200 yards $\mathrm{SE}$ of the ravine.

Weathered clay.

Silty clay with very distinct lamination, varves $7200-7262$.

Blue-gray clay, exceedingly fat, almost like green soap, varves 7147-7199. Thicknesses of varves not good.

Fat clay with good lamination, varves 7045-7I46.

Silty clay with perfect lamination, varves $6967-7044$.

Fine sand, varves $6954-6966$. Varve 6954 is probably bottom varve.

Series measured: 6991-7146, 7199-7262, (6954-6990, 7147-7199).

80. $-2 \frac{1}{2}$ miles NNW of Woodsville, bluff on the eastern side of the Connecticut River, directly opposite Long Meadow Farm.

25 feet sand.

Good varve clay, though with several disturbed zones and one or two zones wholly missing without leaving any trace in the section.

Talus reaching 20 feet down to the river.

Series measured: 6992-7131, 7154-7177, (7200-7209, $7215-7227,7253-7302)$. 
$8 \mathrm{I} .-3 \frac{3}{4}$ miles $\mathrm{N}$ of Woodsville, $\mathrm{I} / 3$ mile $\mathrm{S}$ of East Ryegate station and locality 82 , ravine $\mathrm{E}$ of the Connecticut River, between the river and the road.

7 feet sand.

6 feet clay, partly disturbed.

High section of good varve clay; only a part measured.

Series measured: 7147-7198.

82. -4 miles $\mathrm{N}$ of Woodsville, bluff on the eastern side of the Connecticut River, directly opposite East Ryegate station.

Plain of sedimentation.

2 feet gravel.

Somewhat silty clay with good lamination, varves $7200-7328$.

Fat blue clay with very distinct lamination, varves 6999-7199.

50 feet talus down to river level.

Depth to substratum unknown.

Series measured: 6999-7328.

83. -600 yards $N$ of locality 82 , bluff on the western side of the river.

The clay is covered by 20 feet of sand. It contains many deformed zones. It continues to unknown depth below the river.

Series measured: (7213-7277, 7260-7321, 7307-732I, 7323-7354).

84.- The junction of the Connecticut and Passumpsic Rivers, on the easternmost channel of the Connecticut, 300 yards upstream from its junction with the main river.

Io feet sand, gravel, and cobbles.

25 feet varve clay, not measured.

Exceedingly fat clay, varves $7247-7338$. Varve limits often difficult to distinguish.

The clay continues below river level.

Series measured: $(-247-7338)$. 
85. $-3 / 4$ mile $E$ of the junction of the Connecticut and Passumpsic Rivers, brook ravine Ioo yards $\mathrm{N}$ of the Connecticut.

Second terrace down from the top.

7 feet $\left\{\begin{array}{l}\text { River gravel with cobbles. } \\ \text { Sand. }\end{array}\right.$

20 feet sandy varve clay, about 200 varves. Varve limits very difficult to distinguish.

Exceedingly fat, lead-colored clay, varves 7399 to about 7500. Varve limits marked by hardly distinguishable light streaks of silt. The lowest 60 varves thick.

Fat dark-gray clay, varves 7307-7398. Varve limits often difficult to distinguish. Varve 7307 consists of sharp sand and is $2 \frac{1}{2}$ feet thick. From this varve it is 3 to 4 feet down to till, which shows in the bed of the brook. Consequently varve 7306 (or 7305) may be bottom varve.

Series measured: $7307-7400$ (also several hundred varves above 7400).

86.- - Inwood, Vt., slide 200 yards E of the railroad station.

Plain of sedimentation.

60 feet covered by turf.

Excellent silty clay, varves 7214-7355.

Io feet covered and partly slidden.

Fat clay with very good lamination, varves 7059-7192.

Sandy clay, varves 7036-7058.

Series measured: 7078-7192, 7214-7224, 7238-7294, 7316-7355, (7036-7077, 7225-7237, 7295-7315).

A little to one side and about io feet lower than varve 7036 a series of 8 silty to sandy varves with thicknesses varying from $I \frac{1}{2}$ to 6 feet was measured. Bed rock lies about io feet below the lowest varve.

87.-Inwood, brook ravine 500 yards NNE of the railroad station.

The section is of little value because of several contorted zones.

Series measured: (7039-7046, 7082-7139, 7254-7274, 7306-7320). 
88.-Inwood, 600 yards NNE of the railroad station, slide SE of the farmhouse.

Topmost terrace or plain of sedimentation.

25 feet sand and silt.

Varve sand with very thin winter layers, about 60 varves. Average thickness $3 / 4$ inch.

Varve silt with thin winter layers, about 280 varves. Average thickness $1 / 4$ inch.

Exceedingly fat, lead-colored clay, about 60 varves. Average thickness $2 \frac{1}{4}$ inches. The two lowest varves are numbers 7399 and 7400 .

Silty, excellent varve clay, varves 7288-7398.

Talus. Depth to substratum unknown.

Series measured: 7288-7400, (7401-about 7800) and, close by, 7254-7316.

89.-Inwood, I,000 yards $\mathrm{N}$ of the railroad station, slide $\mathrm{E}$ of the road, $\mathrm{N}$ of the farmhouse.

Gray clay with excellent lamination. Depth to bottom considerable.

Series measured: 7157-7189, 7210-7357.

90.- I00 yards W of locality 89 , bank on the western side of the road.

5 feet weathered and slidden varve clay.

Silty clay, varves $7200-7298$.

Very fat clay, varves 7094-7199.

Depth to bottom considerable.

Series measured: $7094-7298$.

The lamination is very distinct.

91. - 3 miles S of St. Johnsbury, Vt., slide 400 yards SE of Passumpsic station.

20 feet sediments, covered (mostly sand ?).

Clay with clearly defined lamination, varves 7082-7312.

60 feet of sediments, covered, presumably for the most part silt in very thick varves.

Bed rock.

Series measured: 7096-7312, (7082-7095). 


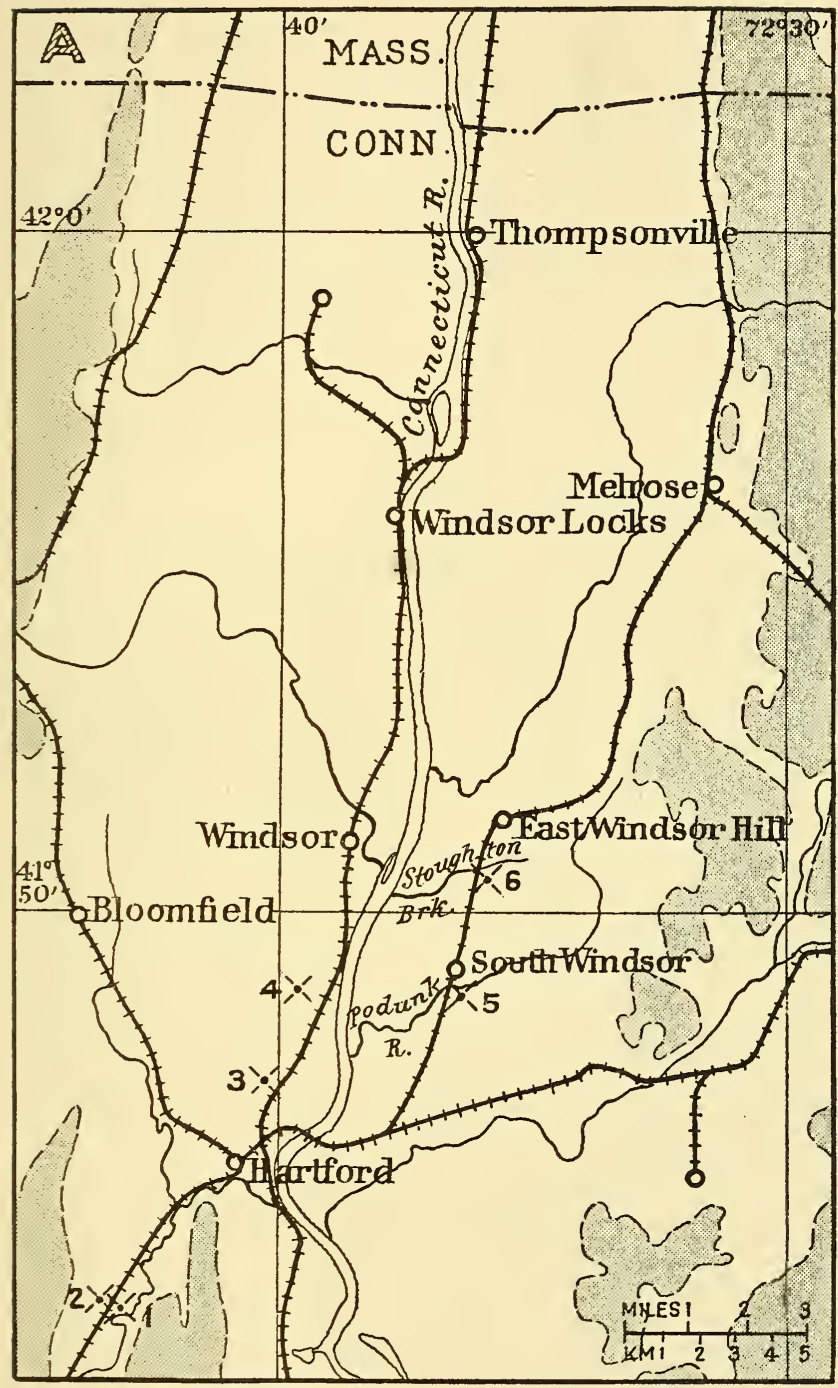

FIG. 5

FIGS. 5-12-Maps showing, by crosses and numbers, the position of the localities examined in the Connecticut Valley. Scale $\mathrm{I}: \mathrm{I} 60,000$.

Outlines of late glacial lakes (area left white): in Connecticut after G. F. Loughlin (1905); in Massachusetts after B. K. Emerson (1898); in New Hampshire and Vermont after C. H. Hitchcock (1878). Topographic base from same sources. For the general location of each map, see the index map on Figs. 8, 9, 10, or I2. 


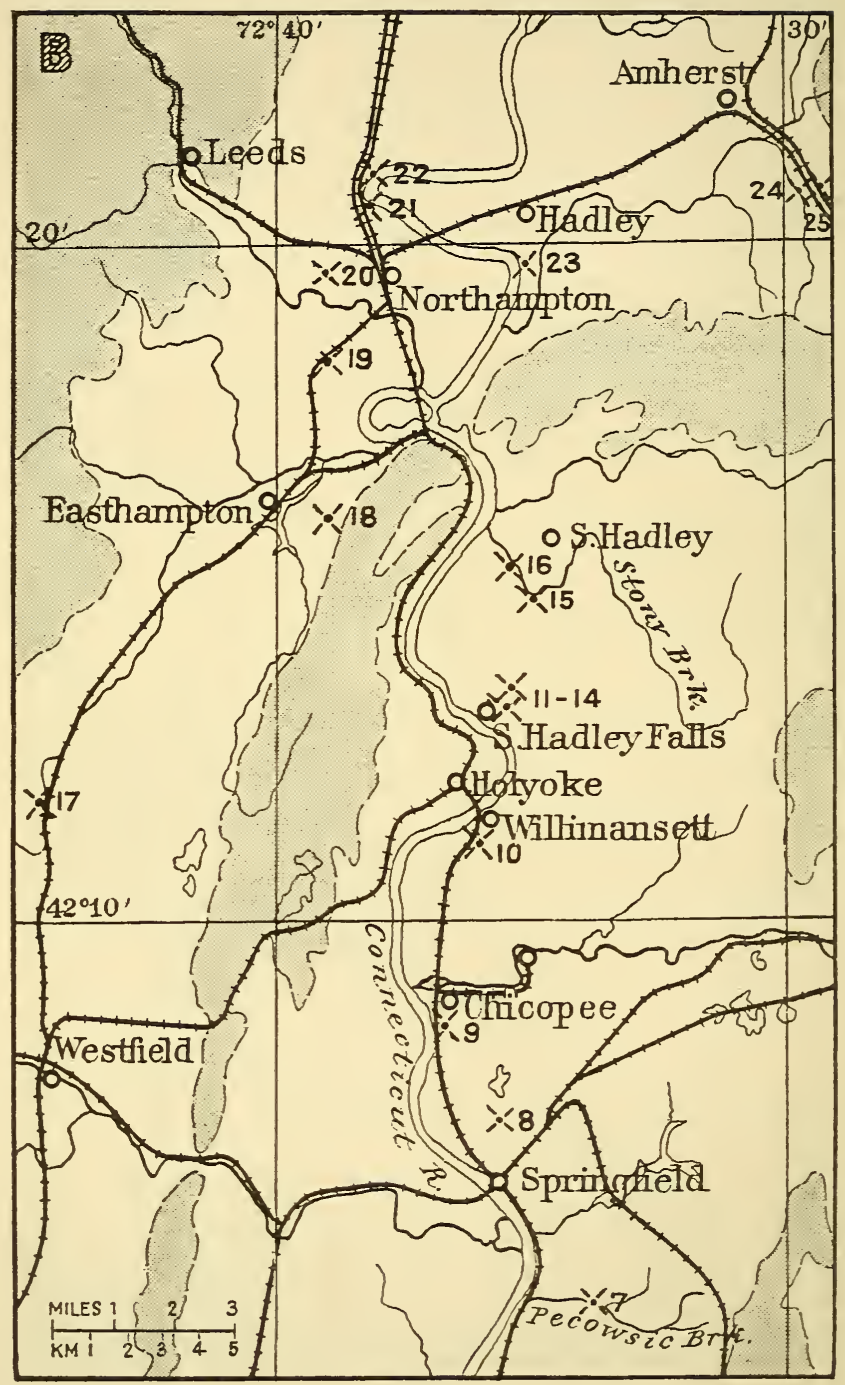

FIG. 6 


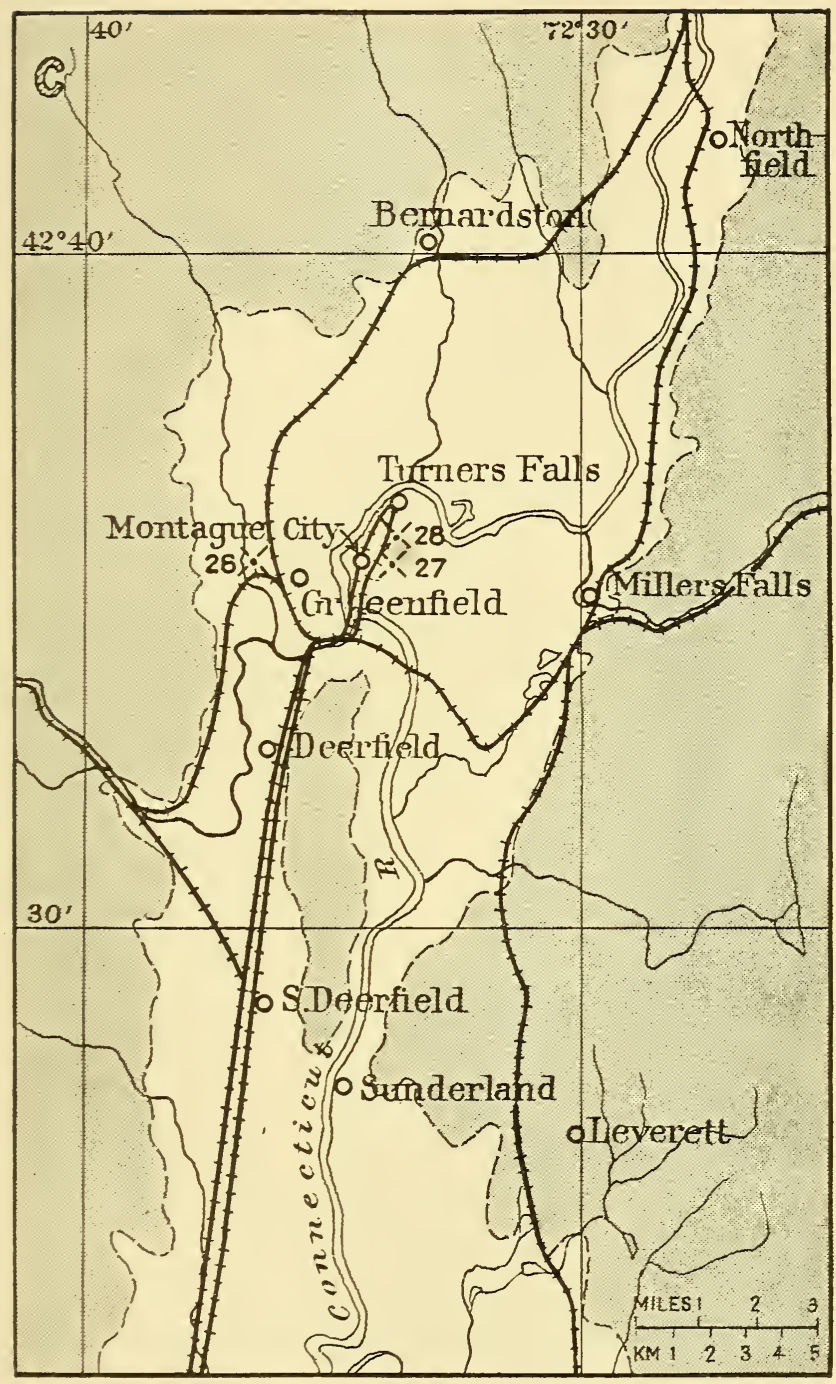

FIG. 7 


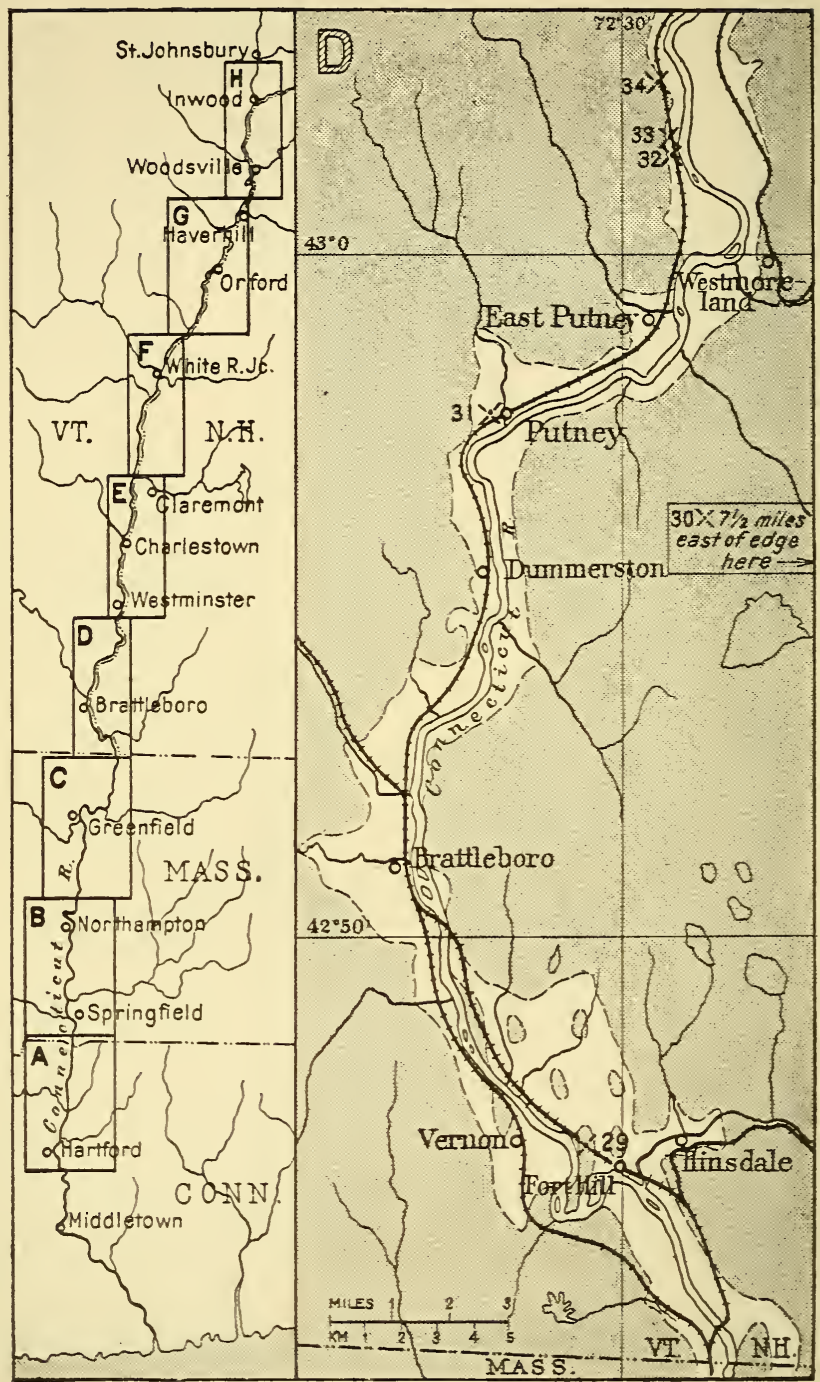

FIG. 8 


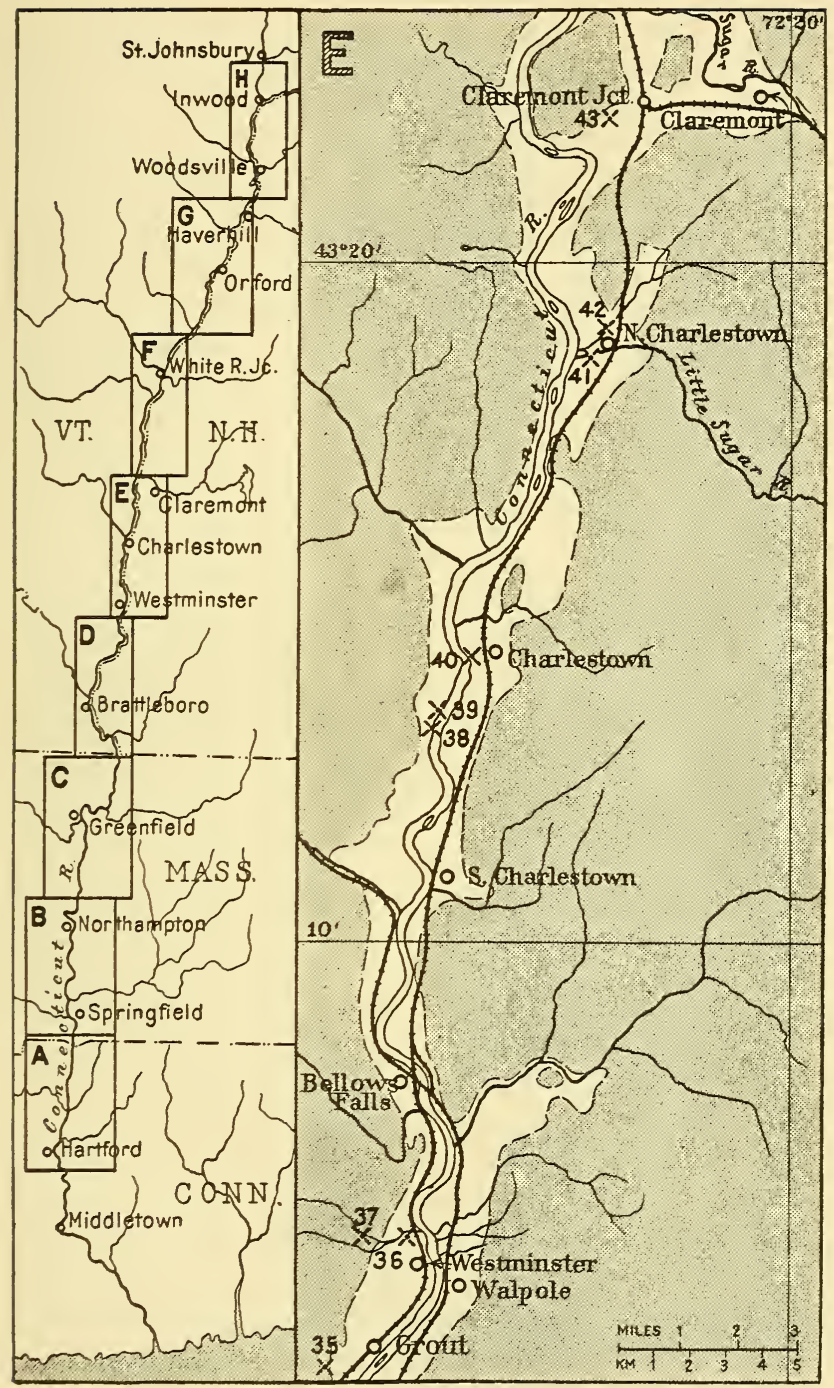

FIG. 9 


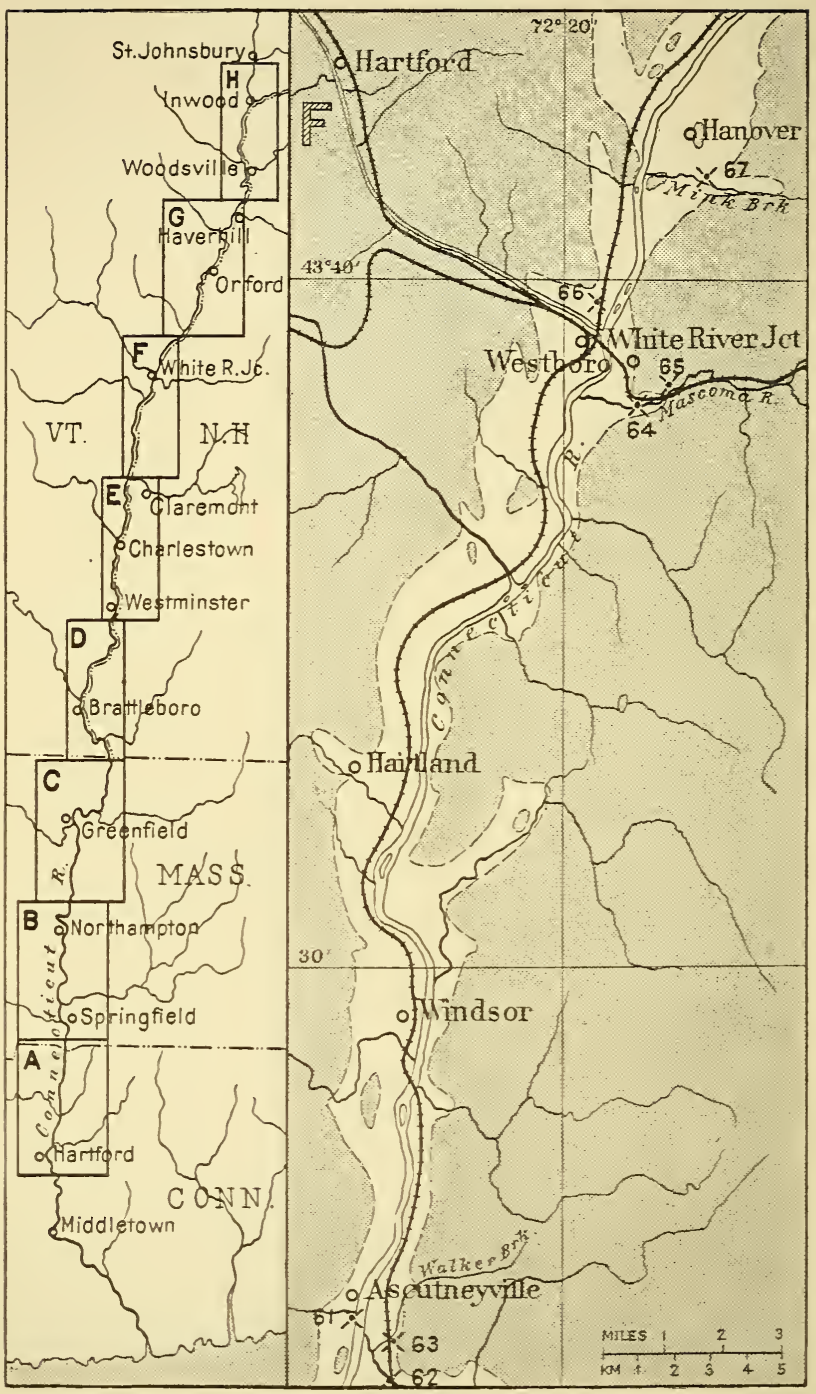

FIG. IO 


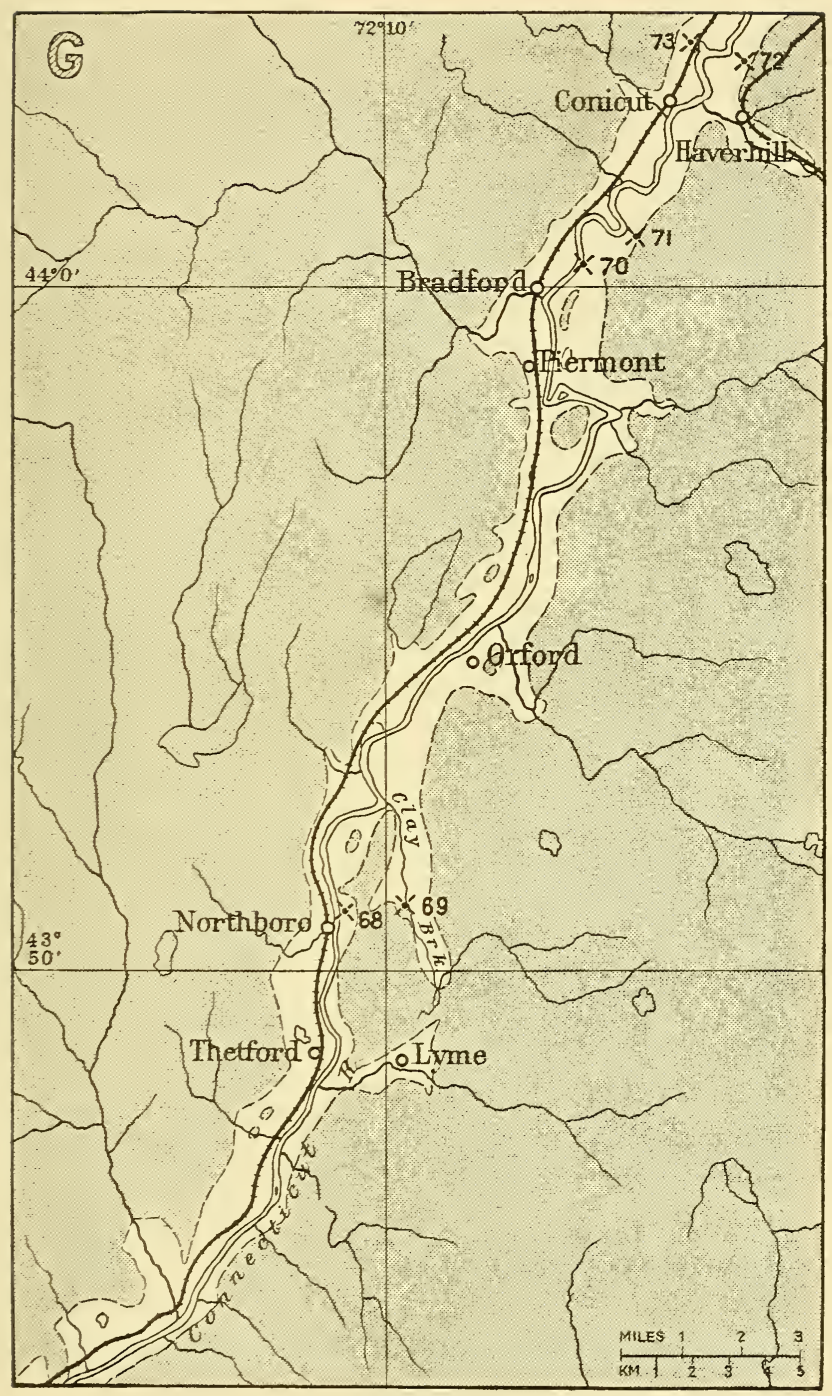

FIG. II 


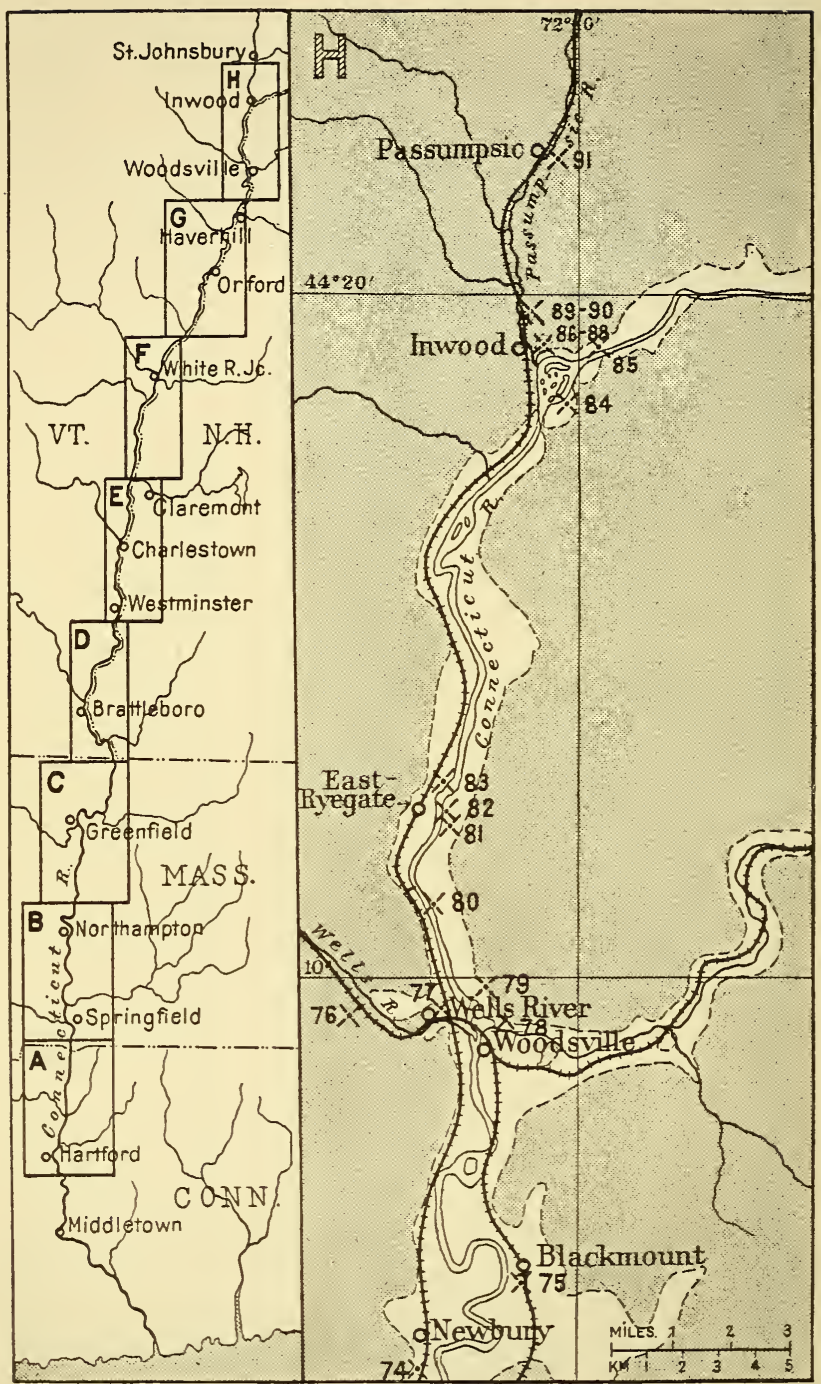

FIG. I2 


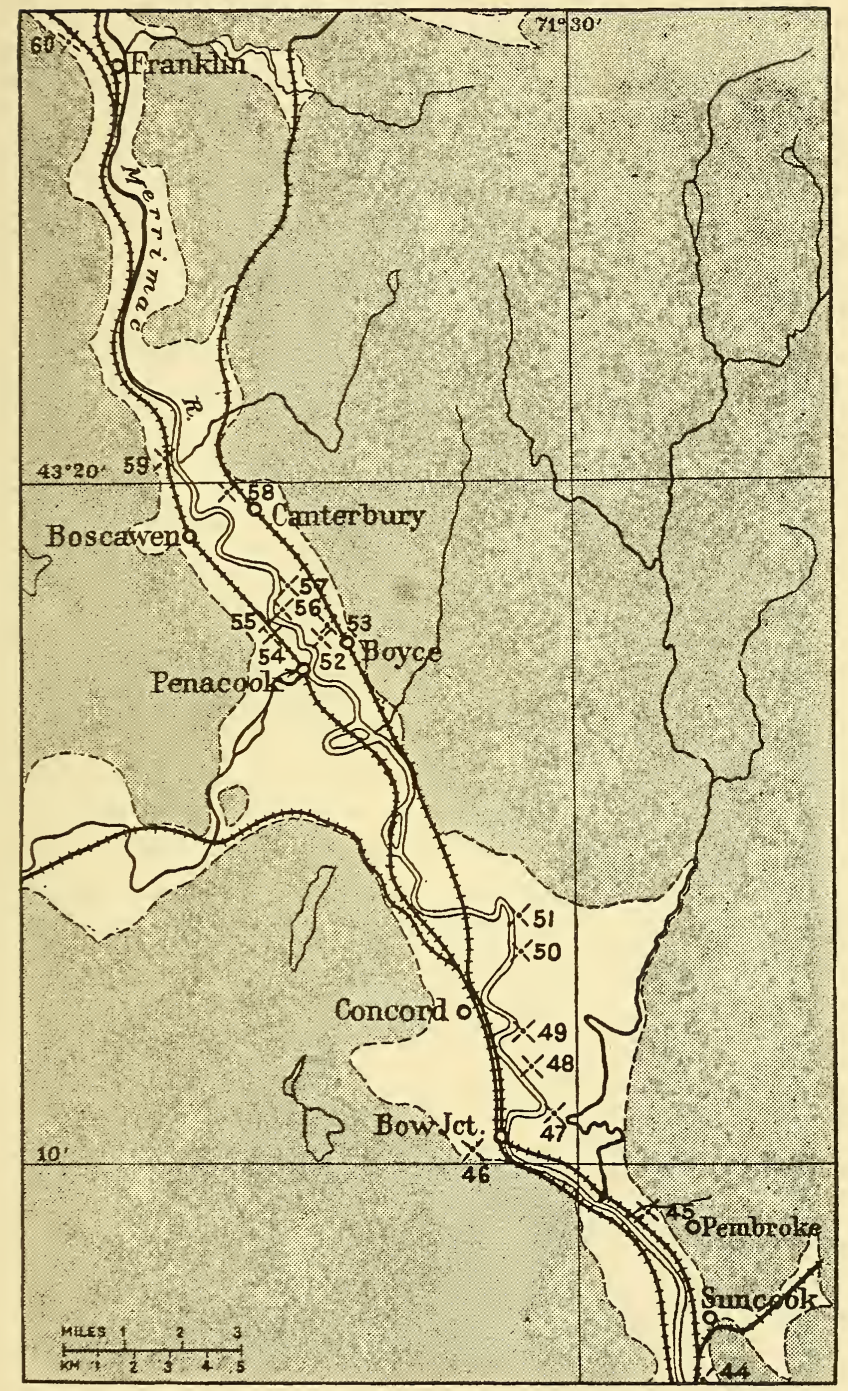

FIG. I3-Map showing the position of the localities examined in the Merrimac Valley. Scale $\mathrm{I}: \mathrm{r} 60,000$.

Outlines of late glacial lake (area left white) and base after C. H. Hitchcock (I878). The course of the river has been considerably changed since 1878 . 


\section{Localities in the Hudson Valley}

On account of a gap, comprising varves 5601 to $57 \mathrm{I} 2$, in the normal curve in southernmost Vermont and New Hampshire, the corresponding zone has been taken from measurements made by the writer, in I92I, in the Hudson Valley. Since the ice recession in the Hudson Valley is to be treated by Baron De Geer, only the necessary series has been made use of; and only the position of the localities will be given (cf. Pl. VI).

a.-Catskill, N. Y., brickyard $1 / 2$ mile SE of the railroad station. b.-Catskill, brickyard a few hundred yards $E$ of the railroad station.

c.- Hudson, N. Y., brickyard a mile NE of the railroad station. d. $-51 / 2$ miles $N$ of Hudson, brickyard on the railroad $\mathrm{I} / 2$ mile $\mathrm{N}$ of Stockport.

e.-Coxsackie, N. Y., old brickyard on the Hudson $3 / 4$ mile NNII of the ferry.

f.-II $1 / 2$ miles $S$ of Albany, $\mathrm{N}$. Y., the southernmost brickyard on the Hudson, $1 / 2$ mile $N$ of Coeymans.

g.-Albany, brickyard on Van Woert Street.

h.-Cohoes, N. Y., brickyard on the Mohawk River at the northwestern edge of the city.

i. - 3 miles NNIT of Cohoes (railroad station), old brickyard on the Mohawk River $3 / 4$ mile $\mathrm{N}$ of Crescent station.

j. -4 miles $\mathrm{NW}$ of Cohoes, brickyard II of the Mohawk River I $1 / 4$ miles NII of Crescent station. 


\section{THE NORMAL CURVE}

\section{Method of Construction}

The curves I to $2 \mathrm{I}$ (Pls. I-V), form together a normal curve of 4,400 years which, with the exception of a gap of 200 to 300 years at Claremont, N. H., records the recession of the last ice sheet from Hartford, Conn., to the region of St. Johnsbury, Vt. To construct it, all individual curves were first matched and corrected for numbers of varves. If, for example, out of four measurements three agreed but one had one varve less or more than the others, the exact location of the mistake was determined and the curve was corrected by dividing one varve in two or uniting two varves in one, so that this curve agreed with the three others. In order to get the number of the varves accurately, as many field measurements were made as time and conditions permitted. Then the curves or such parts of them as included undisturbed varves of normal variation and thickness were selected for constructing the normal curve. To this end the graphs were compared as to thicknesses of the varves and as to fluctuations; and those curves were discarded which showed great difference in thickness from the majority or poor agreement in the shape of the curve. Having for the greater part of the normal curve much material at my disposal, I generally went rather far in discrimination, so that except for too thick or too thin varves many discarded series show excellent correspondence with the normal ones. The normal curve was constructed from the selected individual curves by calculating the average thickness of each single varve. Some varves, however, are abnormal at all localities examined and so have been marked in the normal curve by broken lines (cf. p. 70). 
When measurements of the same series were at hand from distant or differently situated parts of the same lake or from separate valleys, separate normal curves were worked out for each district or valley.

The curve was drawn so that it marked the actual thickness of the varves, except when these were too thick. The distance between the vertical lines was 5 millimeters. In the plates the curve has been reduced one-half. The figures $1 / 2,1 / 4$, etc., indicate the actual scale of each part of the graph. In order to promote continued geochronological studies, the American Geographical Society is willing to make, at cost, photostat copies on the original scale of the normal curve for anyone working on the subject.

\section{Explanation of Symbols on Plates I-V}

In the normal curve the large-sized figures at the arrows indicate the number of measurements used in constructing the curve, and the small-sized figures give the respective localities. Small-sized figures in parentheses indicate profiles used for control of the number of the varves but not otherwise. The arrows show to what part of the curve the figures refer.

\section{No Connection As Yet With Arsolute Time}

This normal curve is not connected with the chronology of our time, and the time elapsed since the ice sheet disappeared from New England cannot even be estimated with any claim of accuracy. The connections which De Geer (I92 I, p. 70) supposed he had made between localities 76 and 78 and the Swedish time scale cannot be right, both because these profiles are not characteristic (cf. p. 32) and because the ice retreat in the respective zones in New England and Sweden was very different. The series given in De Geer's curve, at locality 76 , are 7227 to 7297 and 7338 (?) to 7368 (?), and, at locality 78,7159 to 7266 (?). These horizons essentially correspond to a halt and readvance of the ice edge, while the horizons in Sweden with which thev 
have been matched represent a retreat after the long halt at the Fenno-Scandian moraines. Furthermore, the ice retreat in New England does not show agreement with that in southern and central Sweden. Accordingly, and because I hope to be able to extend the curve southward, the lowest varve measured at Hartford has simply been given the arbitrary number 3001 . The numbers of the varves every ten years from 3001 to 7400 are marked on the base lines of the graphs. For the sake of convenience the curve has been broken every 200 years.

So far as there is material for it, then, the normal curve gives the average thickness of the annual clay layers during the retreat of the last ice sheet across the greater part of New England.

\section{Reliability and Significance of the Varves Measured}

In the following the reliability of the varves measured, from $300 \mathrm{I}$ to 7400 , is discussed by groups of varves, and comment is made on the agreement of curves coveling the same period measured at different localities. Within a group individual varves of special significance are discussed.

300I-3449.-Very good. The ice front was already fairly distant when the lowest of these varves were deposited in the Hartford region. Accordingly, the sedimentation took place under very favorable conditions, and the varve curves from the different localities show a striking correspondence. The thickest varves are silty, and some of them, as for instance 3444 , perhaps represent drainages of ice-ponded lakes.

3188 and 3224 , at locality 5 , contain quicksand and measure $I I / 8$ and $I 5 / 8$ inches $(3$ and $4 \mathrm{~cm}$.) respectively. They perhaps mark drainages.

3450-3500.-The Hartford curve (" 3 Conn.," Pl. I) is good, while the Springfield curve (" 3 Mass.") is less reliable, since the varves are often sandy. The correspondence of the two graphs is fairly good. 
3450-3500.-Continued

3463 is remarkably thick at Springfield and seems to represent a small drainage which made itself felt only locally.

350I-3600.-Very good. The Hartford and Springfield curves agree very well, considering the different distances of the sections from the ice edge and the fact that several varves, at locality 7 , are sandy.

360 I-3623. - The two curves correspond well.

3624-3766.-This horizon, at locality 7 , is sandy. The varves are certainly not thick, and the curve agrees fairly well with the Hartford curve, but it seems proper to exclude the series as not quite good.

The Hartford curve is good, though the clays there consist of very fine material, the varves are thin, and the varve limits sometimes difficult to distinguish, since the deposition took place very far from the ice border.

3767-3871. - On the whole the two curves (4-5 Conn.; 4-5 Mass., Pl. I) agree well, although at Springfield some varves are sandy and at Hartford the varves are very thin.

3820 and 3830 , at locality $I 7$, are sandy and each $41 / 8$ inches (I0.5 cm.) thick, i.e. several times thicker than the other varves. They mark drainages.

3840 and $3866-3870$, at localities 9 and 17 , are sandy and probably represent drainages.

3872-4000.-Very good. The correspondence between the different profiles is excellent.

3931 and 3989 are silty, relatively thick and perhaps register drainages.

3967,3970 , and $397 \mathrm{I}$, at locality 17 only, are sandy and 5 , $33 / 4$, and $31 / 2$ inches $(12.5,9.5$, and $9 \mathrm{~cm}$.) thick respectively.

400I-4200.-Good. The different measurements correspond well. The varves show comparatively great 
4001-4200.-Continued

variation in thickness, and several of them are unusually thick; but whether they are abnormal or not cannot be determined.

4003-4012, at locality 9, are abnormally thick and do not agree with those of the other localities. The thickest varves, 4004 and 4005 , are each $45 / 8$ inches (6.7 $\mathrm{cm}$.). Varves 4004 and $40 \mathrm{II}$ are also thick at localities 10 and 14.

4I23, at localities Io and I4, is silty to sandy and 5 and 7 inches ( 13 and $18 \mathrm{~cm}$.) respectively.

4201-4249. -The curve shows rather strong fluctuations; but whether the thick varves, which are often sandy, are drainage varves or not cannot be made out with certainty. Probably they are normal. The different measurements agree well.

4250-4330.-Good.

4331-4338. - The varves, which register a drainage, consist of quicksand and silt, and the thicknesses are of no value.

4339-4400.-Rather good.

$4357-4396$, at locality 15 , consist of rather coarse sand, and vary in thickness from 2 inches $\left(5 \mathrm{~cm}\right.$.) to $5 \frac{1}{2}$ feet (I.7 m.). The winter layers sometimes were eroded away during the spring following their deposition. At locality $\mathrm{I} 6,3 / 4$ mile $(1.2 \mathrm{~km}$.) to the NW, varves 4387-4396-the varves below 4387 not measuredare sandy but 3 to II times thinner than those at locality I5. Varve 4405, at both localities, begins a long series of thin varves (see p. 15). The horizon in question, at locality 15, lies at an elevation of about 150 feet and, at locality 16 , at a height of about Ioo feet. The glacial lake, according to Emerson (1898, p. 657), reached the level of about 285 feet. Drainage and strong current evidently played a prominent rôle in the development of the 


\section{9-4400.-Continued}

horizon. The difference between the varves at the two localities seems to indicate that the water depth influenced the sedimentation and that the horizon, at locality I5, was deposited in rather shallow water. The case is difficult to understand if the water depths were so great as I 50 feet at locality I 5 and 200 at locality I6. And so it is not unlikely that the lake reached its highest level after year 4400 by the rising of its outlet below Middletown, Conn. (cf. p. 8). This is also corroborated by the fact that the varve silts in the region go over inco sand deep below the highest level of the lake, at locality II, for instance, about iso feet below it.

4398 is relatively much thicker at locality 16 than at locality 15.

4399 and 4400, at localities 15 and I6, are sandy and record a drainage. The thicknesses, at locality 15 , are $31 / 2$ and $5 \frac{1}{8}$ inches $(9$ and $13 \mathrm{~cm}$. ) and at locality 16 , $33 / 4$ and $25 / 8$ inches $(9.5$ and $6.7 \mathrm{~cm}$.).

440I-4600.-Very good. The agreement of the curves is striking even between such localities as 16 and 20 , which are separated by the Holyoke Range and accordingly were very differently situated in relation to the ice border.

4404, at localities 15 and 16 , is sandy and measures 4 and $23 / 8$ inches (Io and $6 \mathrm{~cm}$.) respectively.

4410 , at locality 15 , is sandy and measures $13 / 4$ inches $(4.5 \mathrm{~cm}$.) and so is abnormally thick.

$4520-4528$, at locality 20 , represent a weak drainage which made itself felt only locally. The thickest varve, 4522 , is $13 / 4$ inches $(4.5 \mathrm{~cm}$.).

$455 \mathrm{I}$ and 4552 are silty drainage layers at localities 24 and 25 only. They measure 3 and $15 / 8$ inches $(7.5$ and $4.2 \mathrm{~cm}$.) respectively. 
4401-4600.-Continued

457 I perhaps represents a long and warm summer, since it is thick at all localities measured. It is thickest at locality 22 , where it reaches $2 \mathrm{I} / 2$ inches $(6.5$ $\mathrm{cm}$.).

4586-4634 at locality 20, see page 79 and Figure I6. $460 \mathrm{I}-4800$. - Very good. The ice front stood far north of Northampton, and the sedimentation was very uniform. $4618,4633,4661,4742$, and 4760 are certainly conspicuously thick but may nevertheless represent warm summers. Numbers 4618,4742 , and 4760 are silty in the Northampton region, and 4618 as well south of Amherst.

4654, at locality I9 only, represents an inconsiderable drainage. It contains sand and is $I \frac{1}{4}$ inches $(3 \mathrm{~cm}$.) thick.

480I-5000.-Very good. The different measurements show excellent agreement. This is the case also with the section at locality I 8 which has mostly not been used in calculating the normal curve, because the varves are considerably thinner than those at the other localities.

4823 and 49 II are silty but probably represent warm summers.

500I-5083.-Very good. Like the varves under 5000.

5084-5200.-The agreement between the two curves (both "I I Mass.," Pl. II), is good considering the fact that the upper curve is based on measurements of the proximal parts of the varves and the lower one on such of the distal parts.

5176-5178, at locality 26 , mark a drainage. They contain fine sand and measure $5 \mathrm{I} / 8,23 / 4$, and $25 / 8$ inches ( $13,6.8$, and $6.6 \mathrm{~cm}$.) respectively.

$5184-5200$, at locality 28 , show very great variations in thickness from year to year and therefore have not been used in the normal curve. 
5084-5200.-Continued

5192 , at locality 26 , is relatively much thicker than at point 28.

5201-5400.- In spite of several and considerable drainages the curve from Greenfield (upper "I2 Mass.") shows rather good correspondence with that from Northampton (lower "I2 Mass.").

$5201-5253$, at localities 27 and 28 , show very great fluctuations, and some of them are sandy and attain considerable thicknesses. The thick varves differ greatly at the two localities, though these lie in the same valley and only 600 yards apart (cf. varves $5299-5303$ and $5307-5313$ ).

$5220-5222$, at locality. 26 , and varve 5222 , at localities 27 and 28 , are drainage layers and consist of fine sand and silt. Varve 5222, at localities 27 and 28 , is $91 / 2$ inches $(24 \mathrm{~cm}$.) thick.

$5245-5249$, at locality 26 , are sandy. At localities 27 and 28 they are sandy and very thick.

5253 , at locality 26 , records a drainage.

$5270,5272,5277,528 \mathrm{I}, 5282$, and 5285, at all localities, are sandy.

$528 \mathrm{I}$, at locality 26 , is 4 inches ( $10 \mathrm{~cm}$.) thick and represents a drainage.

5299-5303 and 5307-53I3, at locality 28 , are thick and consist of coarse sand; 5310 is 14 inches $(35 \mathrm{~cm}$.). At locality 27 the same varves do not exceed $\mathrm{I} / 2$ inches ( $4 \mathrm{~cm}$.) (see Fig. 19, and p. 69).

$53 \mathrm{IO}$ and $53 \mathrm{II}$, at locality 26 , are each $2 \mathrm{r} / 3$ inches $(6 \mathrm{~cm}$.) thick and somewhat sandy.

5316 , at locality 28 , measures $41 / 2$ inches (II.5 cm.).

5397 , at locality 26 , is $41 / 8$ inches ( $10.5 \mathrm{~cm}$.).

540I-5437.-Good. The agreement between the Greenfield (upper "I3 Mass.," P1. III) and Northampton (lower "I 3 Mass.") curves is very fine. 
540 I-5437.-Continued

$540 \mathrm{I}$ and 5403 , at locality 28 , are sandy and $23 / 8$ and 2 inches $(6$ and $5 \mathrm{~cm}$.) respectively.

5433 and 5434 , at localities 26 to 28 , are somewhat sandy.

5438-5500.-The agreement among the three curves (the same, and " 13 N. H.") is very good in view of the different conditions under which the clays were deposited in the Greenfield, Northampton, and Hinsdale districts. The thick varves, at locality 29, are sandy.

5452,5457 , and 5495 , at localities 26 to 28 , are somewhat sandy.

$5501-5600$. - Of the curves, one of which is from the Connecticut ("I3 N. H.") and the other from the Hudson Valley ("I3 N. Y."), neither is good. At locality 29, in the Connecticut Valley, the sediments consist of silt and sand deposited in a very narrow lake with a strong current. In the Hudson Valley the material from which the clay was derived was so fine that the whole varve practically consists of fat clay, and the varves consequently are difficult to distinguish. Furthermore, the clay is often slidden. The series 5522 to 5537 is somewhat uncertain, since the varve limits, in both valleys, are exceedingly difficult to distinguish. On the whole, however, the two curves agree well.

560I-57 I2.-Rather good. This series could not be found in the Connecticut Valley. It is therefore borrowed from measurements in the Hudson Valley.

$567 \mathrm{I}-5676$ represent a very considerable drainage (cf. p. 99) 57 I3-5800. - The graph from the Hudson Valley (I4 N. Y.) is continued to show the connection with the New England curves (I4 Vt. and I4 N. H.). The correspondence among them is rather good. Particularly interesting is the fact that most of the 
5713-5800.-Continued exceptionally thick varves agree in all three valleys (cf. p. 54).

5734, in the Connecticut and Merrimac Valleys, is certainly much thicker than in the Hudson Valley and perhaps records a drainage, but this is not quite certain; it might mark an unusually hot summer.

5740 , at locality 45 , and 5783 , in the Hudson Valley, are abnormally thick.

580I-5879. -The curves (both "I 5 N. H.," and "I 5 Vt."), though from separate valleys, correspond comparatively well. The agieement between the two New Hampshire curves is good.

5838 and 5845 , at locality 49 in the Merrimac Valley, measure 2 and $23 / 4$ inches $(5$ and $7 \mathrm{~cm}$.). They consist of coarse sand containing pieces of clay.

$5862,5863,5870,5878$, and 5879 , in the Connecticut Valley, are evidently drainage varves. At locality 34 varves $5870,58,8$, and 5879 are respectively $\mathrm{I} 2,8$, and II inches $(30,2 \mathrm{I}$, and $28 \mathrm{~cm}$.) thick.

5880-6000.-The correspondence between the Connecticut and the Merrimac curves is fairly good.

5SSI, at locality 49 , measures $43 / 8$ inches (I I cm.). It consists of coarse sand containing pieces of clay.

$5907,5916,5974$, and 5991, in the Connecticut Valley, may represent drainages. Varves 5907 and 5916, at locality 34 , are 7 and 12 inches ( 18 and $30 \mathrm{~cm}$.) thick respectively. At locality 32, varves 5973 and 5974 consist of quicksand and measure 7 and II inches ( 18 and $28 \mathrm{~cm}$.).

5954 (or 5955 ?), at locality 49, consists of coarse sand and is $51 / 8$ inches $(13 \mathrm{~cm}$.) thick.

600I-6200.-The correspondence between the two curves is fairly good. Varves $6043,6074,6137$, and 6168 are too thick in the Connecticut Valley (lower "I6 Vt.- 
600I-6200.-Continued

N. H.," Pl. IV). On the other hand a few other varves are somewhat too thick in the Merrimac Valley (upper "I6 Vt.-N. H."), where several of the thickest layers are sandy or silty.

The majority of 6oro-6082, at locality 47 , are thick and more or less sandy, probably mainly because of the fact that the late glacial Suncook River discharged into the lake 4 miles to the northeast.

6037 and 6120 , at locality 31 , are $11 / 2$ and $13 / 4$ inches ( 4 and $4.3 \mathrm{~cm}$.) thick and thus abnormal. At locality 35 varve 6037 is somewhat thinner than varve 6036 , and varve 6120 is somewhat thicker than 6II9.

6074 , at localities 35 and 40 , measures $121 / 2$ and ro inches (25 and $32 \mathrm{~cm}$.) respectively.

Most of the varves $6142-6162$, at locality 52 , are sandy and more or less thicker than at the other localities, probably because the current swept over the locality.

6160 , at locality $3 \mathrm{I}$, is abnormal and $\mathrm{I} / 2$ inches $(4 \mathrm{~cm}$.) thick.

$6178-6183$, at localities 54 and 55 , are sandy and locally too thick because of strong current.

6196 , at locality 54 , is sandy and $31 / 8$ inches $(8 \mathrm{~cm}$.) thick, while, at the adjacent point 55 , it measures $11 / 8$ inches $(3.3 \mathrm{~cm}$.), i.e. is normal

6201-6277. - The correspondence between the two curves (both "I7 Vt.-N .H.") is fairly good. In the Connecticut Valley (lower curve), however, varves 6258 and 6275 , among others, are sandy and too thick.

$6278-6352$. - Fairly good. Varve 6308 is sandy and perhaps of abnormal thickness. Some other varves also are sandy because deposited in very shallow water.

6353-6600.-Gap. 
660I-6607.- Sandy bottom varves, somewhat uncertain.

6608-6628. - Comparatively good, but sandy.

6629-6641.-Good, silty.

6642-6662.-Good. The considerable thicknesses of varves 6643 and 6646 , at locality 63 , may be due to the fact that they were deposited rather close to the ice edge.

6663-6800.-Good. The different measurements correspond very well.

6687 is silty and remarkably thick and perhaps represents a drainage.

6694 is questionable.

$6712-6715$ consist of coarse silt and, no doubt, mark a drainage.

6779 , at locality 65 , contains sand and silt and is $33 / 4$ inches $(9.5 \mathrm{~cm}$.) thick. It may represent a small drainage. 680I-6903.-The curves (both, I9 "Vt.-N. H.," Pl. V) are somewhat uncertain both regarding thicknesses and number of varves. At locality 63 the varves are silty and sandy and have thin winter layers. They are thicker than at points 66 and 67 . The reasons for this may be that they were deposited in shallow water and that several side valleys, of which those now drained by the White River and Mascoma River may be mentioned, join the main valley south of localities 66 and 67 . The section at locality 66 is relatively good. At locality 67 the varves are wavy and have lenses of sand.

6806-6810 are drainage varves. In the curve the thicknesses of the varves at locality 63 are given. Varves 6807 and 6808 consist of sand and silt. The thicknesses at locality 67 are: $13 / 4$ inches $(4.5 \mathrm{~cm}$.); 5 feet 7 inches $(1.7 \mathrm{~m})-$.2 feet $3 \frac{1}{2}$ inches sand +3 feet $33 / 8$ inches silt and clay $(0.7+1.0 \mathrm{~m}$.) -; II $1 / 2$ feet $(3.5 \mathrm{~m})-$.4 feet 7 inches sand +6 feet I I inches silt and clay ( $1.4 \mathrm{~m}$. I/8 $2.1 \mathrm{~m}$.) -; I foot 
6801-6903.-Continued

3 inches $(38 \mathrm{~cm}$.); and I foot $53 / 4$ inches $(45 \mathrm{~cm}$.) respectively. Varve 6806 , accordingly, does not represent drainage at locality 67.

6855 is sandy and marks a drainage.

6903 is relatively much thicker at point 63 (dashed line) than at 67 (full line), indicating a drainage from one of the side valleys.

6904-7000.-Fairly good. The two curves (both, "I9 Vt.-N. H.") correspond rather well.

At locality 63 these varves are silty to sandy with very thin winter layers. The different measurements agree well; this horizon is much better than the series 6801-6903. Some varves, particularly 6928, 6936, 6937, and 6946, are a little too thick. Varve 6997 marks a considerable drainage which originated above locality 67 .

In the Woodsville district (lower curve) there occurred two marked drainages, viz. in 69156917 and 6941-6944. The layers consist of silt. Furthermore, some varves, e. g. 6949 and 6973 , are somewhat too thick. The fact that these drainages, as well as that during year 7007 , are not recorded below locality 68 seems to indicate that there was here a barrier high enough to prevent the suspended material from getting across.

7001-7073.-The correspondence between the two curves (both, "20 Vt.-N. H.") is not good. At locality 63 the sediments consist of silt to sand and probably were deposited in very shallow water. Accordingly the thicknesses of the varves are not reliable. The lower curve, based on the measurements in the Woodsville district, except for some drainages, is good. The different measurements show good agreement.

7007 is sandy and, at localities 79,80 , and 82 , measures 
700I-7073.-Continued

$5 \mathrm{r} / 8, \mathrm{I} 3$, and 6 inches $(\mathrm{I} 3,33$, and $15 \mathrm{~cm}$.). At the localities south of Woodsville this varve is everywhere questionable because of sliding. Judging from the thicknesses the drainage reached the lake in the vicinity of locality 80 .

7020 , in the lake at Woodsville, is silty and too thick.

7028 , at localities $79,70,73$, and other points south of 79 , is silty and about 2 inches $(5 \mathrm{~cm}$.) thick, while, at localities 80 and 82 , it measures $\mathrm{I}$ and $\mathrm{I} I / 4$ inches $(2.6$ and $3.2 \mathrm{~cm}$.) respectively, showing that the drainage originated from one of the side valleys at Woodsville. Since this varve, at locality 76 , is only $3 / 4$ inch $(2 \mathrm{~cm}$.) thick, it probably marks a small drainage through the Ammonoosuc River. 7060-7065 are silty and somewhat doubtful.

7074-7200.- Rather good. The horizon, at most localities, is exceedingly fat, almost like green soap. Consequently the thicknesses of the varves are often altered by pressure from overlying strata. This may be the reason why the correspondence among the different measurements, though fair, is not so good as might be expected. On account of the consistency of the clay, slides occur frequently.

7172-7I8I are more accentuated at locality 82 and at Inwood than at the other localities, but even at Inwood two-thirds to three-quarters of the varves consist of greasy clay,

7200 , at locality 72 , measures $2 \mathrm{r} / 8$ inches $(5.5 \mathrm{~cm}$.); at 73 , $33 / 4$ inches $(9.5 \mathrm{~cm}$.$) ; at 74,2$ inches $(5 \mathrm{~cm}$.); at 77 . $\mathrm{I} 3 / 8$ inches $(3.5 \mathrm{~cm}$.); at $79,43 / 8$ inches (I I cm.); at 80 , ro inches $(25 \mathrm{~cm}$.$) ; at 8 \mathrm{I}, 8 \mathrm{I} / 4$ inches $(2 \mathrm{I}$ $\mathrm{cm}$.$) ; at 82,12 \mathrm{I} / 2$ inches $(32 \mathrm{~cm}$.$) : at 90,153 / 4$ inches $(40 \mathrm{~cm}$.); and at 9I, $43 / 4$ inches ( $12 \mathrm{~cm}$.). At localities 72 to 79 it is silty, at $9 \mathrm{I}$ sandy and silty, and at the rest sandy. It evidently represents 
7074-7200.-Continued

a drainage into the Connecticut above its junction with the Passumpsic (cf. p. 70).

720I-7357.- Very good except for some drainages. The different measurements correspond very well. Besides varves mentioned below some others, like 7254 and 7274 , are somewhat doubtful.

7201 (together with 7200) represents a drainage. It measures, at locality 72 , I inch $(2.5 \mathrm{~cm}$.); at 73 , $\mathrm{I} / 8$ inches $(2.8 \mathrm{~cm}$.$) ; at 77,3 / 4$ inch $(2 \mathrm{~cm}$.); at 78 , I inch $(2.6 \mathrm{~cm}$.$) ; at 79, \mathrm{I} 3 / 8$ inches $(3.5 \mathrm{~cm}$.$) ; at 80$, 2 inches (5 cm.); at 82, 4 inches (I0 cm.); at 90, $5 \mathrm{I} / 4$ inches $(\mathrm{I} 3.5 \mathrm{~cm}$.$) ; and at 9 \mathrm{I}, \mathrm{I} 3 / 4$ inches $(4.5$ cm.) (cf. p. 7o).

7203 marks a drainage. The thickness, at locality 72 , is $2 \mathrm{I} / 8$ inches $(5.3 \mathrm{~cm}$.) ; at $73,23 / 4$ inches $(7 \mathrm{~cm}$.$) ; at$ $77, \mathrm{I} 1 / 4$ inches $(3 \mathrm{~cm}$.); at 79,4 inches (10 $\mathrm{cm}$.); at $80,31 / 8$ inches $(8 \mathrm{~cm}$.); at 81,6 inches $(15 \mathrm{~cm}$.$) ;$ at $82,8 \mathrm{I} / 4$ inches $(2 \mathrm{I} \mathrm{cm}$.$) ; at 90,133 / 4$ inches $(35 \mathrm{~cm}$.); and at 9I, 4 inches (Io cm.). At localities 72 to 77 it consists of silt, at $9 \mathrm{I}$ of silt and fine sand, and at the other points of fine sand. It may represent a drainage into the Connecticut NE of its junction with the Passumpsic (cf. p. 70).

7213 , at locality 73 , measures 7 inches ( $17.5 \mathrm{~cm}$.); at 77 , $33 / 8$ inches $(8.5 \mathrm{~cm}$.$) ; at 79,8$ inches $(20 \mathrm{~cm}$.$) ; at 82$, $23 \frac{1}{2}$ inches $(60 \mathrm{~cm})-.153 / 4$ inches $(40 \mathrm{~cm}$.) sand +8 inches $\left(20 \mathrm{~cm}\right.$.) silt and clay--; at $83,35 \frac{1}{2}$ inches $(90 \mathrm{~cm})-.231 / 2$ inches $(60 \mathrm{~cm}$.) fine sand and silt + I2 inches (30 cm.) clay-; at 90, 271/2 inches $(70 \mathrm{~cm}$.$) ; and at 9 \mathrm{I}, 8 \mathrm{I} / 4$ inches $(2 \mathrm{I} \mathrm{cm}$.$) .$ The varve consists, at 73 and 77 , of silt; at 79 and 90, of fine sand; and, at 9I, of fine sand and silt. Together with varve 7214 it records a drainage into the Connecticut above its junction with the Passumpsic (cf. p. 7o). 


\section{1-7357.-Continued}

$72 \mathrm{I} 4$, at locality 73 , measures $\mathrm{I} 1 / 4$ inches $(3 \mathrm{~cm}$.); at 79 , I inch $(2.5 \mathrm{~cm}$.$) ; at 82,2$ inches $(5.3 \mathrm{~cm}$.); at 83 , $23 / 4$ inches $(6.8 \mathrm{~cm}$.); at $90,23 / 4$ inches $(7 \mathrm{~cm}$.); and at 9I, 2 inches $(5 \mathrm{~cm}$.).

7225 , at localities 82,83 , and 86 , is sandy and abnormally thick. It measures $2 \frac{1}{2}, 4$, and 2 inches (6.5, Io, and $5 \mathrm{~cm}$.) respectively.

$7228-7230$, at localities $82,83,86,89$, and 90 , are silty to sandy and abnormally thick. They, at locality 86 , measure $4,3^{I} / 8$, and $23 / 8$ inches (I0, $8,6 \mathrm{~cm}$.) respectively. Inasmuch as they are thinner at 91 , they evidently mark a drainage into the Connecticut. Down the valley, at locality 73 , this drainage was hardly felt.

7237, at locality 73 , measures $3 / 8$ inch ( $1 \mathrm{~cm}$.); at 79 , $5 / 8$ inch $(1.5 \mathrm{~cm}$.$) ; at 82,2$ inches $(5.3 \mathrm{~cm}$.); at 86 , $31 / 2$ inches $(9 \mathrm{~cm}$.$) ; at 89,23 / 8$ inches $(6 \mathrm{~cm}$.), at 90 , $2 \mathrm{I} / 2$ inches $(6.5 \mathrm{~cm}$.): and, at $9 \mathrm{I}, 7 / 8$ inch $(2.3 \mathrm{~cm}$.). It is, at locality 86 , sandy, but elsewhere silty or clayey.

7295 , at locality 73 , measures $3 / 4$ inch $(2 \mathrm{~cm}$.$) ; at 82,31 / 8$ inches $(8 \mathrm{~cm}$.$) ; at 84,51 / 8$ inches $(13 \mathrm{~cm}$.$) ; at 86$, $33 / 8$ inches $(8.5 \mathrm{~cm}$.$) ; at 88,2$ inches $(5.3 \mathrm{~cm}$.$) ;$ at $89,21 / 4$ inches $(5.8 \mathrm{~cm}$.) ; at $9 \mathrm{I}, \mathrm{I} \mathrm{I} / 8$ inches $(3 \mathrm{~cm}$.). It is sandy at localities $82,86,88$, and 89 .

7296 and 7297 are abnormally thick at localities 86 and 89 . 7304 and 7305 , at locality 73 , measure $7 / 8$ and $I$ inch ( 2.3 and $2.4 \mathrm{~cm}$.) : at $82,23 / 4$ and $51 / 2$ inches $(7$ and $14 \mathrm{~cm}$.); at 83,4 and $191 / 2$ inches ( 10 and $50 \mathrm{~cm}$.); at $84,73 / 4$ and 12 inches ( 19.5 and $3 \mathrm{I} \mathrm{cm}$.); at $86,51 / 8$ and I0 $1 / 2$ inches ( 13 and $27 \mathrm{~cm}$.) ; at 88,3 and $51 / 8$ inches $(7.8$ and $\mathrm{I} 3 \mathrm{~cm}$.$) ; at 9 \mathrm{I}, \mathrm{I} / 8$ and $\mathrm{I} 1 / 2$ inches $(2.8$ and $4 \mathrm{~cm}$.). At locality 84 the varves consist of quicksand, at 83 and 86 , of sand and silt, and elsewhere of silt. 
7201-7357.-Continued

7307 , at locality 73 , measures $3 / 8$ inch (1 cm.); at $82,13 / 8$ inches $(3.5 \mathrm{~cm}$.$) ; at 84,21 / 2$ inches $(6.5 \mathrm{~cm}$.); at 85 , $271 / 2$ inches $(70 \mathrm{~cm}$.$) ; at 86,21 / 2$ inches $(6.5 \mathrm{~cm}$.); at 88,2 inches $(5 \mathrm{~cm}$.); at $89,23 / 8$ inches $(6 \mathrm{~cm}$.$) ;$ at $9 \mathrm{I}, 7 / 8$ inch $(2.3 \mathrm{~cm}$.). At localities 84 and 85 the varve consists of quicksand and coarse sand respectively, at 86 of sand and silt, and at the other localities of silt and clay.

$73 \mathrm{I} 4$, at locality 73 , measures $3 / 8$ inch (I cm.); at $82,31 / 2$ inches $(9 \mathrm{~cm}$.$) ; at 83,101 / 4$ inches $(26 \mathrm{~cm}$.$) ; at 84$, $51 / 8$ inches ( $13 \mathrm{~cm}$.$) ; at 85,51 / 2$ inches ( $14 \mathrm{~cm}$.) ; at $86,41 / 8$ inches ( $10.5 \mathrm{~cm}$.) ; and at 88 and $89,33 / 8$ inches $(8.5 \mathrm{~cm}$.). At locality 85 it consists largely of sand, at $83,84,86$, and 88 of sand and silt, and at the other points of silt and clay.

7358-7400.-Somewhat uncertain because the varve limits are very difficult to distinguish.

7399 begins a series of comparatively thick varves consisting of exceedingly greasy clay. 


\section{CHAPTER V}

\section{THE CONNECTIONS}

The connections of varve curves, as explained on page 4 , are based on agreement among them. Accordingly, it is after all a matter of personal judgment whether connection is found or not. The personal factor, however, can be practically eliminated by only accepting fine and persistent agreement among reliable graphs. The greater the number of graphs which are found to agree, the more certain is the connection. Since the clay sedimentation, i. e. the curves, reflects the climatic fluctuations, and since these are periodical, characteristic features in the graphs often recur somewhat different or exactly similar. But the correspondence, as a rule, persists only for a small group of varves, so that if the profiles are not too short the danger of misconnection is avoided.

\section{Value of Varves for Study According to Their Characteristics}

The value of the varve clays for chronological studies varies greatly. The best varves are one to two inches thick and consist of a silty, light-colored summer layer and a greasy, dark winter layer. They are easy to measure and give the most typical curve. Thick varves are generally good, so long as they do not contain coarser material than silt, but they show sometimes too great annual fluctuations. When they contain sand, they are not reliable, since they then are often entirely too thick and always show exaggerated variations from year to year. Such varves indicate drainage of ice-ponded lakes or deposition close to the ice edge or in strong current or in too shallow water. Very thin varves, besides being difficult to measure, give a curve which 
is too flat and uncharacteristic for sure connections. Very fat clay requires great caution. A section may look perfect, but nevertheless be valueless. At locality 78 measurements a few yards apart, of apparently good series, showed more disagreement than correspondence, because the clay, which resembles green soap in consistency, had been compressed. Another danger is that series of varves of such clay can have slidden away without leaving any trace, even in a long clean section. However, by controlling the measurements with those made at other localities mistakes can be avoided.

\section{Abundance and Quality of New England Material}

The deposition of varve clay in New England occurred under very favorable conditions. The varves are, as a rule, very well developed and of good thickness, and the series show good correspondences almost without exception. Very often the agreement is quite striking. The large amount of material at my disposal has made it possible to control the measurements varve by varve and to discard poor material, as explained on page 47. Often the connections, based on agreeing curves, are supported by such peculiarities as drainage varves and changes in consistency and color of the clay.

\section{Examples of Individual Curves to Illustrate Agreement Among Them}

At the bottom of Plate V, parts of original curves are reproduced so as to give some illustration of their correspondence with one another. There are three groups of curves, the first comprising localities I and 4 (box I), the second localities I5, I8, and 24 (box II), and the third localities 82, 90, and 9I (box III).

Localities I and 4 lie 6.4 miles (I0.4 km.) apart, the latter that much closer to the ice edge (Fig. 5). No alterations whatever of the graphs have been made, since the original measurements 
were correct, as is proved by their agreement with several other profiles (see Pl. I). The correspondence of the two graphs is excellent.

Localities 15,18 , and 24 lie at the following distances from each other: 15 and $18,3.7$ miles ( $6 \mathrm{~km}$.), I5 and $24,8.3$ miles (I3.5 km.); I 8 and $24,9.7$ miles ( $15.7 \mathrm{~km}$.). Localities 18 and 24 are situated in the same glacial lake, though on different sides of it, and locality 15 in a lake separated from the former by the Holyoke Range, except for one or two narrow gaps (Fig. 6). Since most of the material coming from the melting land ice was deposited in the nearer, or Northampton, lake, the varves at localities 18 and 24 are thicker than those at locality 15. Varves $455 \mathrm{I}$ and 4552 , at locality 24 , mark an inconsiderable drainage not felt outside the bay southeast of Amherst. The curves with two exceptions are reproduced exactly as measured in the field. At locality 15 the varves 4553 and 4554 were incorrectly measured as one, and at 18 varve $453 \mathrm{I}$ was divided in two. In the first case, the supposed varve has been divided so as to match those at the other localities, and in the latter case the two varves have been united. These varves have been marked by dotted lines. Considering the different position of the localities in relation to the ice border, the agreement among the three curves is remarkable.

The third group comprises localities 82,90 , and 91. The distance from 82 to 90 is 8.4 miles ( $14.5 \mathrm{~km}$.); from 90 to $9 \mathrm{I}, 3$ miles $(4.8 \mathrm{~km}$.). All three lie in the same glacial lake, but locality $9 \mathrm{I}$ in a narrow branch now constituting the Passumpsic valley, locality 90 in the same branch less than a mile north of its junction with the Connecticut, and 82 farther south in the lake (Fig. 12). Varves 7200 and 7201 are sandy and silty and mark a drainage. Since they are much thinner at locality 9I than at the two other points, the drainage evidently came into the Connecticut above its junction with the Passumpsic. The graphs show the original measurements unchanged, except for two cases in curve 82 , which have been marked by dotted lines. Varves 7116 and 7117 had been incorrectly measured as one, 
and number 7156 had been divided in two. The correspondence among the three curves is excellent.

\section{Agreement Among Curves from Widely Separated LOCALITIES}

The agreement between calculated normal curves from different parts of the same lake, or from widely separated valleys, can be studied on the plates. For details regarding these curves reference may be made to the description on pages 49-63. Curves 3 to 5 (Pl. I) show the striking agreement between normal curves based on two groups of measurements in the same lake, one group lying 20 miles $(32 \mathrm{~km}$.) closer to the ice edge than the other. Curves II, 12, and 13 (Pls. II and III) are constructed from profiles in a corresponding situation to the ice border as those just mentioned. The latter part of graph 13 represents measurements in the Hudson and Connecticut Valleys, and curve I4 (Pl. III) records profiles in the Hudson, Connecticut, and Merrimac Valleys. The distance between the Hudson and Connecticut Valleys is 60 miles ( $95 \mathrm{~km}$.), between the Connecticut and Merrimac Valleys $50(80 \mathrm{~km}$.), and between the Hudson and Merrimac consequently IIo miles (175 km.). The correspondences between the curves are on the whole good, and in some horizons excellent, considering the great distances between these lakes and the differences in their drainage areas. The series from the Hudson Valley is put in to fill a gap in the Connecticut curve, but only so much is reproduced as is necessary to show connections. As a matter of fact, the total series extends 200 varves downward and 100 varves upward, making in all 600 layers. The whole series shows good agreement with the Connecticut and Merrimac curves.

Curves 15, 16, and 17 (Pls. III and IV) are based on measurements in the Connecticut and Merrimac Valleys, and curve I5 also on one in the glacial lake at Keene, N. H. Except for drainage varves the agreement is very satisfactory. Curves I9 and $20(\mathrm{Pl}$. V), finally, are compiled from two groups of measure- 
ments made in probably different lakes (cf. p. 59) in the Connecticut Valley 50 miles $(80 \mathrm{~km}$.) apart. Since the lower lake was supplied with masses of material from its side valleys. principally from the White River valley, the varves at the southern locality, number 63 , are three or four times as thick as those in the Woodsville region. Taking this peculiarity into account, the correspondence between the curves is good.

Sure connections have accordingly been found across New England between points at distances up to I Io miles ( $175 \mathrm{~km}$.) the most widely separated measurements of the same horizons that have been made. This shows that the essentials for getting connections are selection of fine and undisturbed series and accuracy in measurement. Then correct connections can be found irrespective of the distances, so long as we keep within an area which was climatologically uniform during the ice retreat, and provided also the local conditions were not extreme. 


\section{CHAPTER VI}

\section{ABNORMAL VARVES, AND DISTURBANCES IN THE CLAY}

\section{Abrormally Thick Varves}

Now and then single varves or groups of them are abnormally thick and consist of silt or sand covered by the usual thin clay layer. Such varves, as a rule, do not reflect the climatic conditions-the amount of melting-and in other lakes are usually matched by varves of normal thickness. Thick varves can be due to different causes. Some of them were caused by a strong current which for a number of years swept over the locality, depositing silt and sand, and then shifted its course (cf. Fig. I9 and pp. 5I, 54, 57, 82). The cause of other abnormally thick varves lies in an increase of the drainage area by the uncovering of a wider part of the main valley or of extensive tributary valleys (cf. p. 82). In still other cases, deposition of thick varves was due to shallowing of the water as the lakes filled up with sediments or drained out. The depth of water at which deposition of abnormal varves begins varied, of course, according to the situation of the locality, the size of the lake, and the amount of water passing through it. In the lake at Concord, N. H., as explained on page 82 , the critical depth at some points was reached as much as Ioo feet beneath the level of the lake, while in quiet bays clay sedimentation went on until the bottom was built up to within 15 or 20 feet of the lake level (cf. localities 57 and 46).

\section{DRAINAGE VARVES}

Most interesting are those abnormal silty and sandy varves which represent drainages of lakes that were ponded between the ice edge and higher land, or by dams of glacial deposits. 
The extra material in the varves was picked up by the vigorous drainage river along its course. Drainages observed in the clay deposits in New England amount to more than half a hundred. They are rare in the southern part, but numerous from northern Massachusetts northward, where the relief becomes stronger. All drainage varves found are treated under the description of the normal curve on pages 49-63. Although it is desirable to get rid of them in the normal curve, the attempt to do this has not always succeeded. To distinguish them they have been marked by dashed lines. What follows here is only a general account.

While the thickest drainage varve observed, varve 6808 , at locality 67 , Hanover, N. H., is 12 feet $(3.5 \mathrm{~m}$.), many of them are so thin that they are not suspected to be abnormal before they are found to correspond to thin varves in other valleys. This source of mistakes must be kept in mind when using the varve curve as a thermograph and makes measurements in different lakes the more desirable.

Most drainages were inconsiderable and took place during a single year. A great many of them, however, occurred during a number of summers, though generally less than five. Drainages of two and three years are common. In those lasting two years the amount of sediment brought during the first year was in most cases the greater. In drainages continuing for three or more summers the amount of sedimentation usually increased during the first one or two years, reaching a maximum at or before the middle of the period of drainage. Occasionally the first or the last drainage varve is the thickest.

Since the drainage layers grew in thickness towards the mouth of the river by which the ponded lake discharged, the position of this lake can be traced by their help. While so far no detailed studies have been carried out to determine the exact position of ice lakes, the valleys in which they were ponded or through which the discharge took place are in several cases known. Thus Figure 14 shows three drainages which apparently came into the Connecticut above its junction with the Passumpsic, since the 


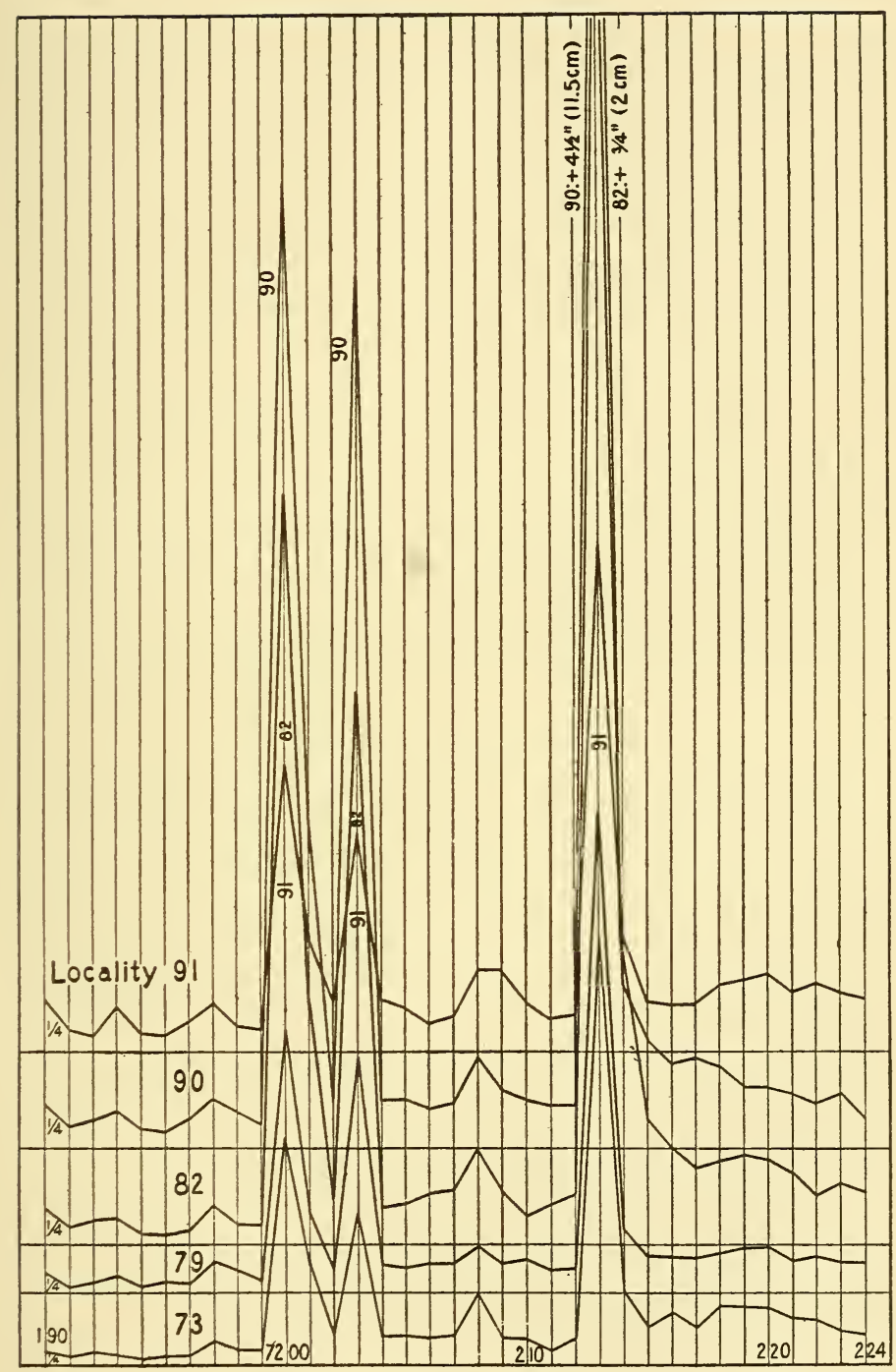

FIG. I4-Curves showing three drainages, into the Connecticut River above its junction with the Passumpsic, of ice-ponded lakes on the northwestern slopes of the White Mountains. 
varves are comparatively thin at locality $9 \mathrm{I}, 3 \mathrm{I} / 2$ miles up the Passumpsic valley. The lakes had probably been dammed on the northwestern slopes of the White Mountains. Varve 6997 (normal curve 19, P1. V) offers another interesting case. The varve, at localities 67 and 63 , marks a great drainage, measuring I6 and I4 inches ( 40.5 and $35.5 \mathrm{~cm}$.), but is normal from locality 68 northward, showing that the drainage originated south of this. Since the ice edge by this time had retired far beyond Woodsville, the lake in question must have been ponded by glacial drift.

\section{Thick Varves as Indications of Warm Summers}

Some unusually thick varves seem to be a true expression of the amount of melting and probably represent very long and warm summers. They illustrate the necessity of having measurements from different valleys in order to understand the meaning of many varves and also show that, in our caution not to assume too great climatic fluctuations, we may easily go too far (cf. p. 56).

\section{Disturbances in the Clay}

Such disturbances in the clay as folded and squeezed zones and faults are essentially of negative scientific interest, because they prevent positive observations. They can have been caused by sliding of the clay, grounding of icebergs, readvancing of the ice sheet, melting of buried ice, sliding or washing down of rock or soil from a hillside, pressure due to the weight of accumulated strata, etc.

Disturbances caused by sliding are frequent in regions where the clay is fat and where it rests on an uneven surface. Sometimes the whole clay deposit has slidden. In other cases a few varves, which formed a shearing plane, are crumpled up so as to appear homogeneous, while the zones below and above are undisturbed. Such contorted zones, one-half to one foot thick, can often be traced continuously through long exposures. In greasy clays slides can occur even if the dip of the strata is slight. 
Disturbances due to grounding of icebergs are usually quite local, even if a great number of varves may have been involved. Sometimes, however, icebergs may have given impulse to extensive slides.

Dislocations due to a readvancing of the ice sheet were more extensive and thorough. The ice jammed the clay beds together, overturned clay blocks, folded the layers, and kneaded sand and till into the clay.

Faults in the clay seem generally to have been caused by settling due to melting away of icebergs which, overloaded with material, had sunk to the lake bottom and had become buried in the sediments.

Disturbances caused by pressure of the clay itself or by the weight of overlying strata are most likely to occur in very fat clay or quicksand. They are treacherous and can sometimes be detected only by comparison of different measurements. 


\section{CHAPTER VII}

\section{THE RATE OF RECESSION AND CONDITIONS CONTROLLING RECESSION}

On account of the very considerable depth of the varve sediments in the New England valleys their bottoms have been reached only at a limited number of localities, almost all of which are situated in New Hampshire and Vermont. Here the rate of retreat, accordingly, has been exactly determined in several instances, while that has not been possible in Connecticut and Massachusetts. However, the bottom of the clay has in many cases been almost reached, enabling an approximate determination of the speed of the retreat.

On the map, Plate VI, the positions of the ice edge have been marked for every 100 years. Which of these positions are determined by bottom varves may be deduced from their location with reference to the localities indicated in Chapter III at which bottom varves were reached. Accelerated retreat between two points indicated by the speed south and north of them has been shown on the map by putting the I00-year lines at different distances, so as to illustrate as truly as possible the gradual increase. Retardation in the recession has been marked in a corresponding way.

The extent of the examined field, which reaches from Hartford, Conn., to St. Johnsbury, Vt., is I85 miles (298 kilometers). The retreat across this belt is registered by a continuous series of annual clay layers except for a narrow gap at Claremont, N. H., probably representing 200 to 300 years. The time occupied by the recession from Hartford to St. Johnsbury was about 4, Ioo years. This makes an average rate of 22 years to a mile, or of 238 feet (73 meters) a year.

The following table gives the rate of retreat of the ice border 
between the points indicated. The distances are measured parallel to the direction of the ice movement.

TABle I-RATE of Retreat OF THE ICE BORder

\begin{tabular}{|c|c|c|c|}
\hline Localities & Distance & $\mid \begin{array}{c}\text { TIME OF RE- } \\
\text { TREAT IN } \\
\text { YEARS }\end{array}$ & $\mid \begin{array}{c}\text { RATE OF } \\
\text { RETREAT A } \\
\text { YEAR }\end{array}$ \\
\hline $\begin{array}{c}\text { I to } 7 \\
\text { None with bottom }\end{array}$ & $\begin{array}{l}24.2 \text { miles }=\mathrm{I} 27.776 \mathrm{feet} \\
38.9 \mathrm{~km} .\end{array}$ & About 525 & $\begin{array}{l}243 \text { feet } \\
74 \mathrm{~m} \text {. }\end{array}$ \\
\hline $\begin{array}{c}7 \text { to } \mathrm{I} 7 \\
\text { None with bottom }\end{array}$ & $\begin{array}{l}5.2 \text { miles }=27.456 \mathrm{feet} \\
8.4 \mathrm{~km} .\end{array}$ & About 330 & $\begin{array}{l}83 \mathrm{feet} \\
26 \mathrm{~m} \text {. }\end{array}$ \\
\hline $\begin{array}{c}7 \text { to } 24 \\
24 \text { with bottom }\end{array}$ & $\begin{array}{l}\text { I9 miles }=\text { I00,320 feet } \\
3 \text { I km. }\end{array}$ & $>\mathrm{I}, 000$ & $\begin{array}{l}<\text { roo feet } \\
<3 \text { I m. }\end{array}$ \\
\hline $\begin{array}{c}7 \text { to } 28 \\
\text { None with bottom }\end{array}$ & $\begin{array}{l}35.8 \text { miles }=189,024 \text { feet } \\
57.6 \mathrm{~km} .\end{array}$ & About 1,630 & $\begin{array}{l}\text { II6 feet } \\
35 \mathrm{~m} \text {. }\end{array}$ \\
\hline 24 to 28 & $\begin{array}{l}\text { I6.8 miles }=88,704 \text { feet } \\
27.1 \mathrm{~km} \text {. }\end{array}$ & About 270 & $\begin{array}{l}328 \mathrm{feet} \\
\mathrm{ro0} \mathrm{m} .\end{array}$ \\
\hline $\begin{array}{c}28 \text { to } 29 \\
\text { None with bottom }\end{array}$ & $\begin{array}{l}\text { I } 2.8 \text { miles }=67.584 \text { feet } \\
20.8 \mathrm{~km} \text {. }\end{array}$ & About 350 & $\begin{array}{l}\text { I93 feet } \\
59 \mathrm{~m} \text {. }\end{array}$ \\
\hline $\begin{array}{c}29 \text { to } 3 I \\
\text { None with bottom }\end{array}$ & $\begin{array}{l}\text { I } 2.4 \text { miles }=65,472 \text { feet } \\
20.1 \mathrm{~km} \text {. }\end{array}$ & About 275 & $\begin{array}{c}238 \text { feet } \\
73 \mathrm{~m} \text {. }\end{array}$ \\
\hline $\begin{array}{c}3 \mathrm{I} \text { to } 40 \\
40 \text { with bottom }\end{array}$ & $\begin{array}{l}\text { I9.5 miles }=102,960 \text { feet } \\
31.4 \mathrm{~km} .\end{array}$ & $>300$ & $\begin{array}{l}<343 \text { feet } \\
<\text { I05 m. }\end{array}$ \\
\hline $\begin{array}{l}45 \text { to } 59 \\
\text { Bottom almost } \\
\text { reached at both }\end{array}$ & $\begin{array}{l}\text { I } 5.2 \text { miles }=80,256 \text { feet } \\
24.4 \mathrm{~km} .\end{array}$ & About 275 & $\begin{array}{l}292 \text { feet } \\
89 \mathrm{~m} \text {. }\end{array}$ \\
\hline $\begin{array}{l}59 \text { to } 60 \\
\text { Depth to bottom } \\
\text { at } 60 \text { unknown }\end{array}$ & $\begin{array}{l}7.2 \text { miles }=38,016 \text { feet } \\
\text { I } 1.6 \mathrm{~km} .\end{array}$ & $<$ I 73 & $\begin{array}{l}>220 \text { feet } \\
>67 \mathrm{~m}\end{array}$ \\
\hline
\end{tabular}


TABle I-RATE OF Retreat OF the ICE BORDER-Continued

\begin{tabular}{|c|c|c|c|}
\hline LOCALities & Distance & $\begin{array}{c}\text { TIME OF RE- } \\
\text { TREAT IN } \\
\text { YEARS }\end{array}$ & $\begin{array}{c}\text { RATE OF } \\
\text { RETREAT A } \\
\text { YEAR }\end{array}$ \\
\hline $\begin{array}{l}\text { 6I to } 64 \\
\text { Both with bottom }\end{array}$ & $\begin{array}{l}\text { I } 5.5 \text { miles }=8 \mathrm{I}, 840 \text { feet } \\
25 \mathrm{~km} .\end{array}$ & I33 & $\begin{array}{l}6 \text { is feet } \\
\text { I } 88 \mathrm{~m} .\end{array}$ \\
\hline $\begin{array}{l}64 \text { to } 67 \\
67 \text { practically with } \\
\text { bottom }\end{array}$ & $\begin{array}{l}4 \text { miles }=2 \mathrm{I}, \mathrm{I} 20 \text { feet } \\
6.4 \mathrm{~km} .\end{array}$ & $<26$ & $\begin{array}{l}>812 \text { feet } \\
>246 \mathrm{~m}\end{array}$ \\
\hline $\begin{array}{l}67 \text { to } 70 \\
\text { Both practically } \\
\text { with bottom }\end{array}$ & $\begin{array}{l}2 \text { I miles }=\text { I I } 0,880 \text { feet } \\
33.8 \mathrm{~km} \text {. }\end{array}$ & $>\mathrm{I}_{4} \mathrm{I}$ & $\begin{array}{l}<786 \text { feet } \\
<240 \mathrm{~m}\end{array}$ \\
\hline $\begin{array}{l}70 \text { to } 7 \mathrm{I} \\
7 \mathrm{I} \text { with bottom }\end{array}$ & $\begin{array}{l}1 / 2 \text { mile }=2,640 \text { feet } \\
0.8 \mathrm{~km} .\end{array}$ & 3 & $\begin{array}{l}880 \text { feet } \\
268 \mathrm{~m} .\end{array}$ \\
\hline $\begin{array}{c}70 \text { to } 75 \\
75 \text { with bottom }\end{array}$ & $\begin{array}{l}6 \text { miles }=31,680 \text { feet } \\
9.7 \mathrm{~km} .\end{array}$ & 29 & $\begin{array}{l}\text { I092 feet } \\
333 \mathrm{~m} \text {. }\end{array}$ \\
\hline $\begin{array}{l}75 \text { to } 79 \\
\text { Both with bottom }\end{array}$ & $\begin{array}{l}5 \text { miles }=26,400 \text { feet } \\
8 \mathrm{~km} .\end{array}$ & 24 & $\begin{array}{l}\text { I I } 00 \text { feet } \\
335 \mathrm{~m} \text {. }\end{array}$ \\
\hline $\begin{array}{l}79 \text { to } 86 \\
86 \text { practically with } \\
\text { bottom }\end{array}$ & $\begin{array}{l}\text { I I miles }=58,080 \text { feet } \\
\text { I } 7.7 \mathrm{~km} .\end{array}$ & About 70 & $\begin{array}{l}830 \text { feet } \\
253 \mathrm{~m} \text {. }\end{array}$ \\
\hline
\end{tabular}

\section{Rate of Recession in the Southern Zone}

In the southernmost zone, between Hartford and Springfield, the recession was consequently rather fast, amounting to about 243 feet $(74 \mathrm{~m}$.$) a year. In Massachusetts the rate decreased$ considerably, areraging between Springfield and Greenfield only II 6 feet $(35 \mathrm{~m}$.) annually. The recession, however, seems to have varied greatly in speed in different zones and even to have been interrupted by readvances. Between localities 7 and 24 the retreat was less than 100 feet (3I m.) a year. 


\section{Probable Oscillations of the Ice Border in the AMHERST-NORTHAMPTON REGION}

In November, I92I, there was, at locality 24, southeast of Amherst, an excellent long vertical section, part of which is shown in Figure I5. The sequence of strata is clear on the left side of the section. The thicknesses are as follows, beginning at the top:

$2 \mathrm{~T} / 2$ feet till.

$2 \frac{1}{2}$ feet crumpled clay, about I 50 varves.

Io feet excellent clay, varves $445^{0}-4668$.

I $1 / 2$ feet till.

More than $I \frac{1}{2}$ feet quicksand.

To the right, the whole clay bed is crumbled down to the till. The pressure which folded the clay seems to have come from the west-northwest. The connection between the covering till and the folding of the clay is evident, but the circumstances under which the till was deposited are not clear. Those small

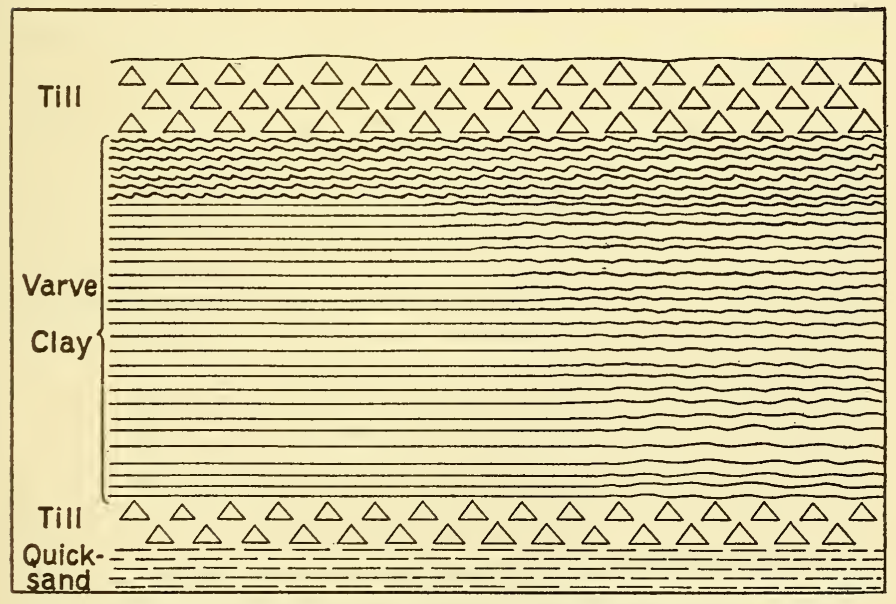

FIG. I5-Section at locality 24, southeast of Amherst, Mass., showing till on top of the varve clay and partial folding of the clay by pressure from the west-northwest. 


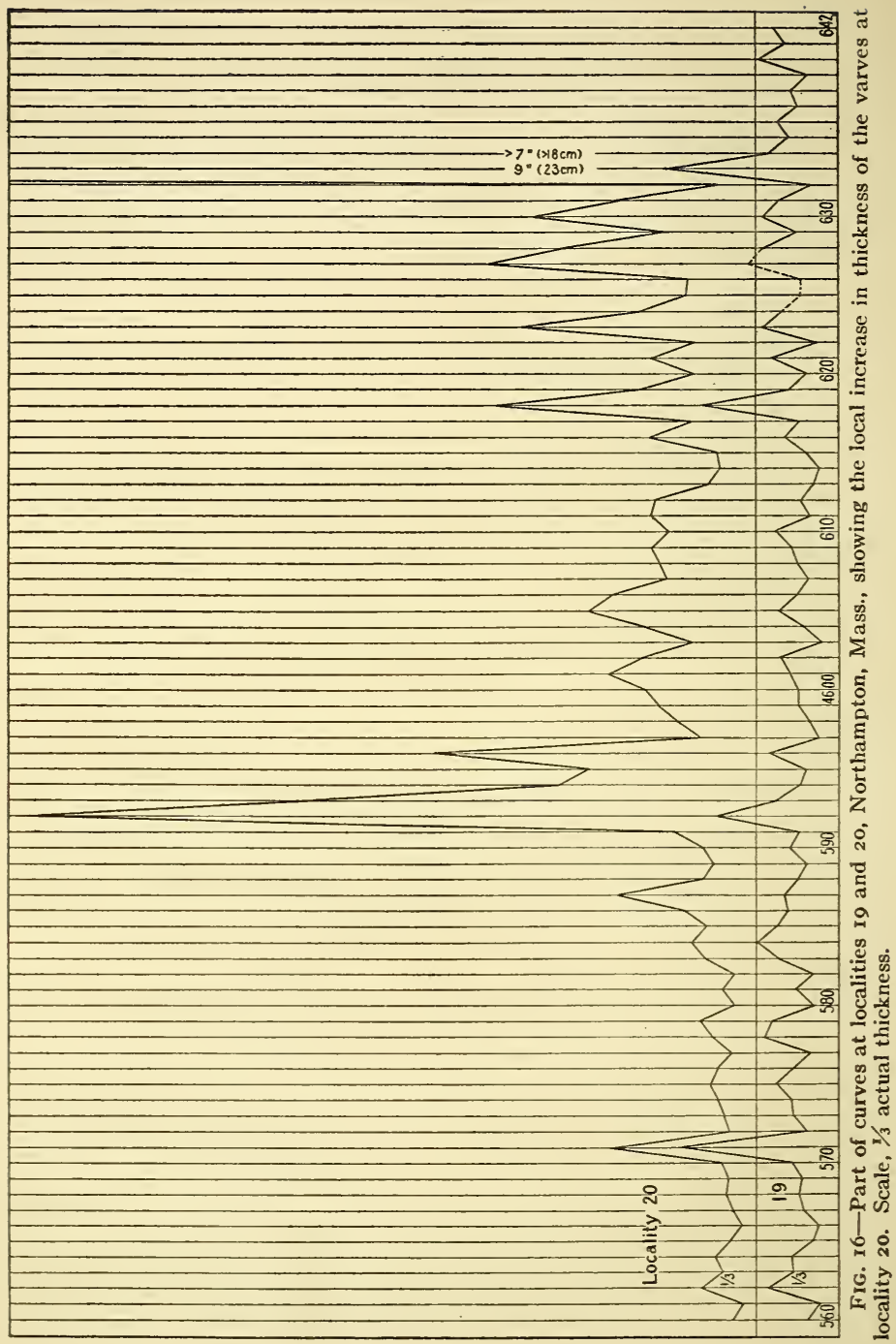


icebergs which were broken off in the glacial lake can hardly have been able to push together a clay bed so thick. That a landslide was the cause is equally improbable, since the ground towards the west rises only 60 feet in the first half-mile, where it reaches the foot of a drumlin whose crest is only I 40 feet above the locality. The last possible explanation, that the ice edge readvanced, pushed together the clay, and deposited the till cover, also meets some difficulty. The readvance would have occurred about year 4800 , i.e. at a time when deposition of clay proceeded undisturbed at Northampton, 7 miles to the west. Since locality 28 , the ice edge at which lay I6.8 miles $(27 . \mathrm{I} \mathrm{km}$.) north of the ice edge when at locality 24 , was uncovered by the ice before year 5084 , the annual recession of the ice from 24 to 28 must have averaged about 328 feet (100 m.). This fact, however, forms no obstacle. Within less than 220 years after the halt at Claremont, N. H., the annual recession amounted to 615 feet (I88 m.; see p. 76), and in Finland Sauramo (I9I8, p. 3I) found that the rate of retreat was most rapid just after a halt or a slow recession.

At locality 20, situated at the northwestern edge of Northampton, the following section was measured, beginning at the top:

3 feet sand.

2 feet weathered and disturbed varve clay.

I $1 / 2$ feet clay, I ro varves, not connected with the normal curve.

I3 feet silty clay, homogeneous through disturbance.

4 feet quicksand, slidden at the top, varves 4633 and 4634 .

Silty clay, sandy at the top, varves $4377-4632$.

Depth to bottom unknown.

Figure 16 shows in one-third actual thickness varves $4560-4634$ at this locality and, for the sake of comparison, varves $4560-4642$ at locality $\mathrm{I} 9$, situated $\mathrm{I} \mathrm{I} / 2$ miles to the south. The most interesting thing about profile 20 is the increase in thickness of the varves beginning with number 4586 . Varve 4587 and those from 4592 upward consist of quicksand. Below number 4586 the layers have about the same thickness as at the other localities in the region but consist of somewhat coarser material. The 
greater thickness of the varves can hardly be due to decreasing depth because of sedimentation at the locality, since this lies about 125 feet below the level of the glacial lake, and since the varres are exceptionally well developed. Shallow-water varves have heterogeneous material and thin and indistinct winter layers, as well as wavy surfaces. Nor is it likely that the reason is drainage, because this ought to have been felt over a large part of the lake, if not over the whole of it. The fact can hardly have been caused by a shorter distance from the locality to the mouth of the eventual Mill River of that time, since this would have discharged into a bay three miles northwest of it, i.e. as far away from here as from localities 19 and 21 . So it seems most probable that the zone indicates an approach of the ice border which during year 4635 or somewhat later overrode the clay, crumpling up its upper part. It would have been a local tongue, extending from the northwest, since deposition of clay proceeded at other points in the vicinity. If, however, the lake during years 4586 to 4634 did not stand at its highest level (cf. p. 52), it may be possible that the thick varves were due to some of the other possible reasons mentioned as alternatives.

North of Northampton, close to my localities 21 and 22, Emerson (1898, p. 686, and Pl. I8, Fig. 3) in I880 found in a long railway cut, in the midst of alternating till and sand beds, contorted varve clay. The overlying till was no doubt deposited by the land ice during a marked oscillation of its border. The unusually complete disturbances of the clay at localities 2 I and 22 also make it probable that they once or several times were overlapped by the ice.

To sum up, there are in the Northampton-Amherst zone different facts which seem to indicate oscillations of the ice edge. If the conditions are correctly explained, the ice border returned to locality 20 during year 4635 or somewhat later, after having left it more than 258 years earlier; it returned to locality 24 about year 4800 , or some 350 years after it first left; and to localities $2 \mathrm{I}$ and 22 at some other date not known. Furthermore, the 
rate of the final ice retreat between localities 24 and 28 amounted to 328 feet $(100 \mathrm{~m}$.) a year. Further investigations are needed to reveal the actual conditions.

\section{Rate of Recession in the Middle Zone}

In northern Massachusetts the amount of the annual recession was 193 feet $(59 \mathrm{~m}$.). The rate of retreat increased until the ice edge reached the Bellows Falls region, whereupon it decreased again, judging from the halt of the ice edge at Claremont and from results obtained in the Merrimac Valley. When fastest, the recession reached approximately 370 feet ( $113 \mathrm{~m}$.) a year.

In the Merrimac Valley the retreat was a little slower than in the Connecticut, probably because it was situated closer to the sea, where the sky was more clouded. The highest rate was reached a little north of Concord. The subsequent retardation was rather noticeable.

\section{Oscillations in the Lake WinNepesauke Region}

In the Claremont-Lake Winnepesaukee zone the ice edge again halted and readvanced. At locality 4I, in the Connecticut Valley, four feet of coarse gravel with several boulders a foot in diameter overlie discordantly a thick deposit of varve sand which represents more than 50 years (see p. 22). The gravel is, no doubt, outwash deposited during a readvance of the ice edge. Around Lake Winnepesaukee till in doubtless its original position frequently overlies varve clay, marking oscillations of the ice border (Upham, I878, p. I3I). A few such localities were visited by Goldthwait and the writer. At Clay Point, 3 miles southwest of Wolfeboro, at the southeastern end of the lake, the varve clay, which according to Upham is at least 15 feet thick, is now covered by talus. The original position of the overlying till is obvious. At Weirs, on the western side of the lake, a third of a mile north of the railroad station. a 30 to 40 -foot 
section at the bottom of a hill shows the following layers, beginning at the top:

2 feet till, mostly blocks.

4-8 feet silty and sandy disturbed clay. Varves $1 / 3$ to 4 inches (I to Io $\mathrm{cm}$.) thick. Varve limits difficult to distinguish.

3-4 feet stratified sand.

$1 / 3-3$ feet disturbed varve clay.

Thick varve clay with several disturbed zones and here and there morainic material. The clay consists of sand or silt and of thick, greasy clay layers, but the varve limits, in many cases, cannot be determined. At the bottom of the section the varves are sandy and 6 to 8 inches ( 5 to $20 \mathrm{~cm}$.) thick, probably indicating inconsiderable depth to the base of the deposit.

The covering till may have been deposited by the land ice, judging from Upham's statement that on the top of the hill, the sides of which show till at the surface, a well 27 feet deep encountered only varve clay. The consistency of the clay seems also to show that it was deposited off a practically stationary ice edge. The sand bed may mark a readvance almost to the spot. After a short renewed retreat the ice overrode the clay and deposited the till cover.

This halt is not registered in the normal curve, because I did not succeed in getting varve series so long that they bridged it and could be connected with profiles north of the zone. In the Connecticut Valley the Bellows Falls lake was filled up with sediments probably about 300 years before the ice uncovered localities $6 \mathrm{I}$ to 63 north of the zone of retardation. Not even localities 4I and 43 can be connected with those south of them. Nor is the halt recorded in the Merrimac Valley. The lake at Concord also was filled up with sediments too early, though certainly 75 years later than the Bellows Falls lake. As the ice retired and began to uncover the outlet of the IVinnepesaukee basin, the drainage area, tributary to the Merrimac, became very large, and the volume of water passing through very considerable. The increase of the current was followed by increase of the critical depth of clay sedimentation in the course of the current. At points swept by the current sand was deposited 
even in deep water, and so the varves at closely situated localities in the middle of the lake sometimes differ greatly in thickness. At locality 52 deposition of sand started during year 6232 at a water depth of about 75 feet, and at locality 57 during year 6308 at a depth of about 100 feet. After the critical depth of clay sedimentation had been reached at a given point the lake there was filled up with sand and silt in a few decades (cf. pp. 25-28). My attempts to bridge the gap in the Hudson and Mohawk Valleys were also without result, in the former because the clays did not offer any exposures and in the latter on account of the general absence of clays. How many varves are lacking in the normal curve cannot, of course, be stated, but their number in view of the facts known seems to amount to 200 or 300. If this estimate is correct, the retardation and the readvance should represent at least 400 years.

\section{Rate of Recession in Northern Zone}

As soon as the recession from this line had started it seems to have become quite rapid, since between localities $6 \mathrm{I}$ and 64 , i.e. during the first 100 or 200 years, it averaged 615 feet $(188 \mathrm{~m}$. a year. Between White River and Hanover it reached over 8I2 feet $(246 \mathrm{~m}$.). After a slight decrease it increased again and reached, between localities 75 and $79, \mathrm{I}, \mathrm{I} 00$ feet $(335 \mathrm{~m}$.) a year, the fastest rate observed in New England. Then the speed diminished again, amounting, between localities 79 and 86 , to about 830 feet $(253 \mathrm{~m}$.) a year. When the ice edge had retired beyond St. Johnsbury it probably halted and readvanced. Since I hope to be able soon to collect more material regarding the conditions in this region, at this time it may merely be stated that the ice border seems to have readvanced to St. Johnsbury in the Passumpsic Valley and to the junction with the Passumpsic in the Connecticut Valley. The final retreat of the ice from locality 85 occurred about 280 years after it uncovered locality 86 , a mile to the west. The halt seems to correspond to the one registered by moraines at Bethlehem and Littleton, 
I5 miles $(24 \mathrm{~km}$.) east of here, which have been mapped by Goldthwait (I9I6). As for the length of time represented by the halt, 280 years may be a minimum figure.

\section{Rate of Retreat and Type of Clay}

Difference in thickness between varves is usually due to variation of the coarse summer layers, the winter layers being almost equally thick from year to year. Accordingly, thin varves contain a greater percentage of fine material than do thick ones. The thickness of the varves, the amount of sedimentation, is a measure of the amount of melting. Since slow recession and halt of the ice border, as observed by De Geer long ago, are usually recorded by thinner and more greasy varves than is fast recession, it is evident that the retardations were characterized by little melting, in other words, by low temperature (cf. p. 86). Thus the clay gives an idea of the rate of the retreat and of the climatic conditions, especially in regions which, like Fenno-Scandia, are built up of hard, coarse Archean rocks (see also Sauramo, I9I8, p. 37). This rule, however, can be applied only with the greatest caution to districts occupied by both hard and soft rocks. A soft, fine-grained slate or schist evidently gave rise to a fatter clay than did a hard, coarse-grained granite, regardless of the amount of melting. There occur, therefore, in New England clays deposited during rapid recession consisting exclusively of such fine material that the varve limits cannot be distinguished.

Another reason why the thickness and texture of the varves cannot be used as indicators of the ice retreat in New England is the fact that, in the small lakes which occupied the valleys, thick and thin varves often only mean large or small drainage area. It is particularly significant that during an annual recession of more than $\mathrm{I}, 000$ feet $(300 \mathrm{~m}$.) comparatively thin and fat clay varves were deposited in the Connecticut Valley at Woodsville, while at locality 63,50 miles farther from the ice front but below important tributaries, the same varves are silty and three to four times as thick. 
When the details of the ice retreat are known, it will be possible to discriminate between peculiarities dependent upon the character of the mother rock and those due to the rate of recession or to the climate.

\section{Conditions Controlling Recession}

The factors causing and influencing the disappearance of the ice sheets were many and different: temperature, precipitation in form of snow and in form of warm rains, topographic conditions, conditions favoring discharge of icebergs, etc. The ice itself moved forward, and the retreat of the ice edge was the excess of the melting over the advance. The combinations of the factors were complicated and changing, and so in many cases they cannot yet be analyzed; but detailed and exact chronological studies promise to shed light upon these fundamental questions.

\section{TEMPERATURE}

The importance of the summer temperature is probably best shown by De Geer's studies in Sweden (I9I2, I9I2a, I9I4). The most significant evidence is perhaps the great difference in the rate of the recession of the ice on the Swedish west coast and that in the Baltic region. In western Sweden the ice edge stood practically still for one or two thousand years, while it receded at great speed in the eastern part of the country. De Geer's explanation is that on the west coast the air was very foggy and the temperature low and constant, while in the Baltic region the sky was clear and warm and sunny days were frequent. The intensely dense fog along the Gulf Stream in the Arctic is well known. On Bear Island, halfway between Norway and Spitsbergen, the writer from the beginning of August to the middle of October in I9I6 saw the sun in all for but a few hours. The summer temperature on this island is, on the average, a few degrees above the freezing point and exceedingly even. In other Arctic regions, as Spitsbergen, the insolation on bright 
days can be very high, causing the glaciers to melt considerably and the rivers to swell strongly (see also Hann, I9II).

The nourishment of the ice sheet, which, as Hobbs (I9II, p. 287; I9IIa, I9I5) points out, largely occurs in such a way that the snow, fallen during a relative calm, is by violent anticyclonic surface air currents swept from all central portions of the ice sheet and deposited near and about the margins of the ice shield, may perhass have become greater in western Sweden, but that does not explain the rapid recession in the Baltic region. Nor can the discharge of bergs from the ice front explain the different rate of retreat. In the present Baltic area, as well as in the surrounding lowlands, which were submerged below the Baltic of that time, calving doubtless played an important rôle, particularly where the waters were deep and wide and the lifting power and wave action was great. But since the supply of ice in these regions was greater than in the supramarine parts of eastern Sweden, the recession was almost as fast in these latter.

The important part played by sunshine as compared with that of rain is evident, for the Swedish west coast, in late glacial time, had doubtless much more rain than had the Baltic district. Rains in Arctic regions are also usually cold and sparse.

Indication of the great importance of temperature seems also to be found in the thicknesses of the varves, which varied greatly from year to year. If the recession had been mainly determined by conditions of precipitation, it is to be expected that the recession and the clay sedimentation should have been practically the same from year to year and should have undergone only slow variation.

Variations of temperature seem also usually to be the causes of the long and marked fluctuations in the rate of recession, which themselves, to be sure, can be readily explained by changes in precipitation, since in Sweden and Finland the thicknesses of the varves are found as a rule to stand in good relation to the rate of retreat and the thin varves deposited during halts indicate inconsiderable melting (cf. p. 84). 


\section{TOPOGRAPHY}

The influence of topography was important. The direction of striae and the position of recessional moraines indicate the fact, and detailed mapping of the ice front by means of the clays reveal it still better, as researches in Sweden have shown. The rate of flow of the ice was rapid in valleys and basins, while it was checked on highlands. In the marginal zone the distal parts of the valleys were filled with protruding ice lobes, though discharging of icebergs counterbalanced their formation. As the ice edge withdrew, the lobes gradually disappeared, and, when the ice front reached the northern, proximal end of the valley, it had become concave. The flow of the ice, though now slower, was yet more rapid than in the higher neighboring parts, but it was more than counterbalanced by calving.

\section{PRECIPITATION}

A valuation of the influence of precipitation, or nourishment of the ice, is particularly difficult, since this had much the same effects as the temperature and may have co-operated with it in the great advances, readvances, and recessions. For certain local readvances of the ice, not due to topographic conditions, precipitation may have played the leading part, since this is likely to show greater differences between near-by regions, topographically similar, than does the temperature. The ice lobes southwest of Lake Superior may be taken as examples.

There seems to be one known case of a halt in the retreat in Fenno-Scandia chiefly determined by increased precipitation, namely that at the Inner Salpausselkä in southern Finland. While the ice edge halted for 183 years at this morainic line (Sauramo, I918, pp. $35,38,43,44$ ), which in some districts, is divided into a series of moraines, a clay consisting almost exclusively of fine material was deposited, as usual during halts. In contradiction to the rule, however, the varves marking the halt are considerably thicker than those deposited during the 
previous retreat, which was rather slow. Sauramo does not give an explanation of the case. It seems evident that the lack of coarse material indicates absence of strong currents of the ice water. In other words, there was at no time in the summer rapid melting. Warm sunny days must have been few or none, and the temperature very even. On the other hand, the melting must have lasted for several months, since the sedimentation was great. The fact that the ice edge on the whole did not withdraw under these circumstances seems to prove that the nourishment of the ice was much greater than usual. This is an interesting case of equilibrium between a great supply of ice and considerable melting at low temperature. The clay probably does not indicate short summers and long winters, as supposed by Brückner (192I, p. 57 ; cf. our p. 3). 


\section{CHAPTER VIII}

\section{THE CLIMATE DURING THE RECESSION, AND CLIMATIC PERIODICITY}

\section{The Climate During the Disappearance of the Ice}

The climate during the disappearance of the ice in New England has been touched upon in the preceding pages. Since, as explained there, the summer temperature seems to have been the chief factor in the melting of the ice, the rate of retreat gives an idea of the temperature. And since the rate of recession varied considerably in the different zones (see pp. 74-84), the temperature also may have undergone great fluctuations. The climate was not arctic, for the melting of the ice, in many zones, was quite rapid. Since, however, a vast amount of heat was used in the melting of the ice and heating of the cold ice water, the temperature remained comparatively low in a belt off the ice front. This arctic to subarctic zone shifted northward as the ice front withdrew. It doubtless accommodated an arctic and subarctic fauna and flora, about which, however, very little is yet known. Although relicts of these northern plants and animals still survive on the highest summits in New England, only a few occurrences in the varve clays seem to have been reported. In the varve clay at Northampton, Mass., particularly at my locality 23, Emerson (1898, p. 718 ) found remains of the following plants: Viola palustris L., Vaccinium oxycoccus L., Vaccinium uliginosum L., Rhododendron lapponicum Wahl., Arctostaphylos alpina Spr., Arctostaphylos uva ursi Spr., Oxyria digyna Campd., Salix cutleri Tuck., and Lycopodium selago L. Of these, Salix cutleri and Vaccinium oxycoccus are very abundant. The plants indicate an arctic to subarctic climate. They were deposited when the ice border uncovered northernmost Massachusetts. They must have grown in this region or still closer to the ice edge, since any transportation must have been southward. I am 
informed by Mr. R. W. Sayles that in varve clay taken by him at locality 78 , about io feet above the till, Dr. E. C. Jeffrey found microscopic fragments of coniferous wood.

In Sweden the rate of the ice retreat from the south coast of Blekinge $\left(56^{\circ} \mathrm{N}\right.$.) to Ragunda $\left(63^{\circ} \mathrm{N}\right.$.) in Norrland ( 450 miles, or $720 \mathrm{~km}$., in 4,000 years) averaged about 600 feet ( $180 \mathrm{~m}$.) a year (De Geer, 1912, 1915). In the southern part, from Blekinge to the Fenno-Scandian moraines ( 150 miles, or $240 \mathrm{~km}$., in 2,000 years), the annual recession amounted to 400 feet ( $120 \mathrm{~m}$.), and in the northern part, from the moraines up to Ragunda ( 280 miles, or $450 \mathrm{~km}$., in $\mathrm{I}, 500$ years) to $\mathrm{I}, 000$ feet $(300 \mathrm{~m}$.). The morainic belt represents two halts and slow intervening recession for together nearly 700 years (Sauramo, 1918, p. 23).

In New England, between Hartford, Conn., and St. Johnsbury, Vt. (I 85 miles, or $298 \mathrm{~km}$., in 4, I00 years), a zone lying closer to the periphery of the last ice sheet than does Sweden, the annual recession averaged about 240 feet $(75 \mathrm{~m}$.), i. e. less than one-half of that in Sweden. Assuming that during the ice retreat the supply of ice was the same in Sweden and New England and that the rate of recession reflects the temperature to the same extent in both regions, it must have been considerably warmer in Sweden when the ice disappeared there. Accordingly, the knowledge of the late glacial climate in Sweden cannot be directly applied to New England. As far as this is based on the immigration of the flora, it should be noted that this migration occurred on a narrow front across the Danish islands, which from time to time connected Sweden with the continent (Antevs, I922), while the migration northward in New England occurred on abroad front.

In southern Sweden the land uncovered from the vanishing ice was first taken possession of by an arctic to subartic flora with Dryas octopetala as its most typical constituent. Even before the disappearance of this flora, birch (Betula odorata and Betula verrucosa) and pine (Pinus silvestris) were more or less abundant (von Post, I9I6). The temperature may have corresponded to that now prevailing in northern Scandinavia (Andersson and Birger, I912, p. I30). Alder (Alnus glutinosa), elm (Ulmus 
montana), linden (Tilia europaea), and hazel (Corylus avellana) immigrated almost immediately after the extinction of the arctic flora and occurred in the whole of southern Sweden in early post-glacial time, that is to say about 2,000 years after the release of the ice (von Post, I916). At the present time alder and elm occur to beyond the 65th parallel of latitude, and linden and hazel in the coast region up to the 63rd parallel, or central Norrland. In northern Sweden the land was from the beginning occupied by a temperate pine flora, essentially similar to the present vegetation of the region (von Post, I9II, p. 20). Thus the amelioration of the climate, in late glacial time, became more and more noticeable. Towards the end of the epoch the arctic belt, which had previously followed the retiring ice edge, had ceased to exist.

\section{The Varve Studies As a Key to Climatic Periodicity}

The clay studies, when they shall have been carried out in detail, will increase our knowledge of climatic periodicity. They furnish perhaps the best material known for the study of long periods and one of the best for that of short ones. Since the disappearance of the ice was due to climatic reasons, the periodicity in climate is recorded by the annual amount of ice melting, the rate of recession of the ice edge-recession, halt, and readvance - and the amount of sedimentation (cf. pp. 85-88). The short periods, that is to say those up to a few decades in length, are best illustrated by the amount of sedimentation, by the varve graphs. The long cycles are shown by the rate of recession.

Study of the climatic periods is one of my chief purposes in measuring so great a number of sections and working out the normal curve. For the elimination of local, non-climatic features, material from different lakes is necessary. Therefore at present only parts of the normal curve are fit for the analysis of periods; other parts may be perfectly good but should be controlled. For the analysis of long periods, more detailed studies of the rate of ice retreat are necessary. While time has not permitted 


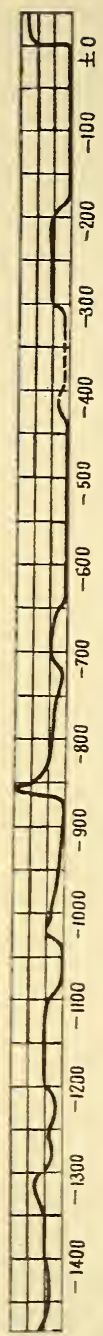

Б్ํ용ㅇ an analysis of the graphs for the recognition of short periods, and the study of long cycles cannot be made without more data, some problems and conditions may be pointed out in order to encourage the collecting of more material.

\section{Recognizable Cycles}

The period of II years, or the sun-spot cycle, together with its multiples, seems to play a prominent rôle in the clay sedimentation. In the growth of trees the same cycles are predominant, as Douglass (I9I9, p. 99) has shown. He has determined periods of II $\div 2$ ( 5 to 6 ), II , $2 \times$ II ( 2 I to 24$)$, $3 \times$ II (32 to 35 ), and $3 \times 3 \times$ II (I00 to 105) years, as well as of 2 years.

The lines of recession as drawn on Plate VI do not pretend to give an accurate picture of the varying rate of ice retreat; for that a much more detailed study is necessary. It is likely that the rate varied a good deal more than the map suggests. In the Berkshires, Taylor (1903) has mapped a series of recessional moraines, the most conspicuous of which are reproduced on Plate VI. As Taylor points out, they must represent short periodical halts in the ice retreat. Because of their wide spacing they cannot be winter moraines, i.e. moraines pushed together by a slight readvance of the ice edge during the winter after a summer of considerable recession, but record periods of some length. On the map an attempt has been made to connect two moraines with two positions of the ice edge. Unfortunately, these latter are not accurately fixed. Assuming that the connections are correct, Taylor's morainic line No. 2 should correspond to the ice edge position 4800 , and his line No. II to that of 5300 . Accordingly, there should be nine 
periods marked by moraines in 500 years, which gives the cycles an average length of 55 years. This is exactly five sun-spot cycles. At the present time no period of 55 years seems to be known. If we assume that the nine periods represent 600 years instead of 500 , the length of the cycles would be 67 years, that is to say two of Brückner's 35-year periods. Determination of the length of the period-i.e. the time of recession and halt-by clay measurements would be of very great value. In the clay graphs there are no particularly thin varves which could be supposed to record these halts. It would perhaps be hasty to conclude from this that the pauses were due to increased ice supply rather than to lower temperature and decreased melting.

In Sauramo's (1918, Pl. 3) diagram of the ice retreat in southern Finland, based on a very detailed study, the fluctuations of the rate are striking (Fig. I7). Leaving out of consideration the part -650 to \pm 0 , which represents the Fenno-Scandian moraines, the Outer and the Inner Salpausselkä (cf.p. 87), the ice edge halted or receded slowly on four occasions, at - I225, - I050, -880, and -725. According to Sauramo's (1918, Pl. 4) graphs, the varves are practically normal during the years - I225 to - I22I. They are uniformly thin during parts of the halt - I085 to - I035, particularly during - I062 to - I05I. The varves -900 to -872 , i.e. those for the whole halt, are especially at Saurano's locality 19 thin and uniform. The halt -725 is not distinguishable in the curves. This halt is marked by a chain of transverse eskers (see Sauramo, I9I8, Pl. I). The average length of the periods is 167 years, or five times the Brückner cycle. The facts seem to indicate that the halts were primarily, but not exclusively, due to low temperature.

The climate during the ice retreat also underwent changes of longer amplitude. The length of the period recorded by the readvances at Amherst and Claremont is about I,700, and that by those at Claremont and Inwood about 800 years. One-third to one-fourth of the periods were occupied by readvances of the ice edge. 


\section{CHAPTER IX}

\section{THE BEARING OF THESE STUDIES ON PREVIOUS WORK AND ON NEW PROBLEMS}

\section{Previous KNowledge of the Ice Retreat}

The map compiled by Goldthwait (PI. VI) illustrates the retreat of the last ice sheet in the Northeastern States. It shows the general direction of the ice flow as based on striae, drumlins, and boulder trains and the outermost limit marked by the terminal moraines; it shows interruptions of the ice retreat as recorded by recessional moraines and other phenomena; it indicates the late glacial marine submergence of the coast region north of Boston and the rate of recession of the ice front as worked out by the clay studies.

The ice flow, seen on the map, is, so far as can be judged, that which prevailed during the time of the ice retreat. The center of the ice lobe covering the Northeastern States followed the great topographical lines, the Champlain-Hudson lowland and the Green Mountains, which trend north and south, and flowed directly southward across Vermont. In southern New England, where the relief is less marked and where the ice flow was strong in the valleys but weak in the lee of the highlands, subordinate lobes were developed in the Hudson and Connecticut Valleys. East of the Connecticut River the ice movement diverged toward the southeast. West of the lower Connecticut the motion was somewhat westerly. In the lower and central Hudson region the ice spread strongly toward both sides.

During the ice recession the Hudson lobe retired more slowly than the Connecticut lobe and deployed. It invaded western Connecticut and Massachusetts, crossing the earlier direction of the ice flow. The ice front in the Berkshires, as revealed by Taylor's (1903) studies of the recessional moraines, had a 
northeast-southwest direction. In the Catskill Mountains and northwest of them the trend of the ice edge was northwestsoutheast, as shown by T. C. Chamberlin's and Rich's studies of moraines and striae. Hence the whole mountain group was covered by a large lobe the eastern edge of which transgressed the border of Connecticut and Massachusetts. When the ice edge had left the Catskill Mountains, the lobe vanished rapidly, so that at Cohoes the ice front had an almost east-west direction.

The ice crossed the Adirondack Mountains in a southsouthwest direction, but it was so thin and the movement was so slow that the relative lack of ice south of them caused the lobes on either side to join and cross each other in the Mohawk Valley.

In western New York the ice motion was largely determined by the Ontario basin and to some extent by the topography of the Finger Lakes district.

\section{Confirmations Through the Varve Studies}

The geochronological studies confirm the little which was known about the rate of the ice retreat (see pp. 74-84). Where Emerson at Northampton, Mass., had indications of a halt and readvance, there the clays furnish independent evidence of the same thing. In the same zone as the till-covered varve clays on Lake Winnepesaukee, which Upham described, evidences for a halt are also found on the Connecticut at Claremont. Fifteen miles west of the recessional moraines which Goldthwait mapped at Bethlehem, on the northwestern slope of the White Mountains, a readvance is recorded in the clays. In zones where no indications of halts have been found the recession proves to have been more or less rapid.

It is the same thing with the trend of the ice edge. The ice front, fixed by connections between Cohoes, N. Y., and Concord, $\mathrm{N}$. H., runs at right angles to the general direction of the ice flow. Likewise the simultaneous uncovering of the site of Hud- 
son, N. Y., and the northern border of Massachusetts where this crosses the Connecticut River agrees with the trend of Taylor's recessional moraines in the Berkshire Hills and with the general direction of the ice movement there.

\section{Their Contribution to the Problem of the Glacial Correlation of the Great Lakes Region AND New England}

One of the great problems in the Quaternary geology of North America is the correlation of the ice retreat in New England with that of the Great Lakes region. Through the detailed studies of Leverett and Taylor the conditions in the last-mentioned area are well known. Morainic lines marking successive ice fronts are mapped and correlated from the Dakotas eastward to western New York. But the correlatives of these moraines in eastern New York and New England are unknown.

A comparison of the ice retreat in the two regions, at the first glance, suggests more differences than correspondences. The disagreement, however, is more ostensible than real, and may essentially be due to the different topographic conditions. Most conspicuous is the great abundance of stadial moraines in the Great Lakes region and the practical absence of them in New England. The basins now occupied by the Great Lakes brought about the development of big ice lobes which easily pushed forward and, favored by the flatness of the land, built continuous though often weak moraines, while in hilly New England the ice probably readvanced shorter distances and could not pile up any coherent ridges. Some of the faint moraines in the lake region might perhaps rather be ridges of ground moraine than moraines accumulated along the ice front. Whether all the differences between the two regions are due to topographic conditions or not is difficult to tell. It seems possible that there was disagreement also in other respects, most likely in ice supply. It is practically sure, however, that the retreat in both districts was determined primarily by an amelioration of climate and that temperature played the chief rôle also for the readvances. 
Therefore it is highly probable that readvances in the one region were matched by readvances in the other, and periods of recession in the one by those in the other, even if there were some differences in details.

The first halt and readvance of the ice in New England north of Hartford, Conn., was in central Massachusetts. In the Hudson Valley this zone comes just south of Kingston, which was uncovered about year 4900 (Pl. VI). From Kingston the ice edge, as just mentioned, formed a bow towards the northwest, and so the moraines in the Catskills and northwest of them almost surely record the zone of readvance. Between Utica and Syracuse, as seen on the map, there was a wide re-entrant in the ice sheet, while in the lowland of the Finger Lakes protruded a big lobe. Accordingly this readvance seems to be traceable the whole distance from Massachusetts to the western side of the Finger Lakes.

In the Erie and adjacent basins glacial Lake Arkona existed during a pause after a recession of the ice front (Taylor, 1915, p. 375). The ice barrier is not exactly located; but it stood in about the same position as for Lake Warren, i.e. at the Niagara Falls moraine. Lake Arkona was followed by Lake Whittlesey, which was caused by a marked readvance of the ice (Taylor, I915, pp. 376 and 384). This ice front is marked by the Port Huron morainic system, which parallels the northeastern and northern coast of the southern peninsula of Michigan 5 to 40 miles inland (Taylor, 1915, P1. 32), and by the Alden moraine south of Buffalo (PI. VI). The moraines have been followed from Wisconsin entirely across the Great Lakes region to the Genesee River in western New York. All facts indicate a general and great change in climate which surely ought to have its correlative in eastern New York and New England. The Alden moraine points toward the moraines south of the Finger Lakes, which in their turn ought to have their correlatives in the Great Lakes region. Hence it is exceedingly likely that the Port Huron-Alden moraine, the Finger Lakes moraine, and the overridden clays at Northampton, Mass., correspond to each other. 


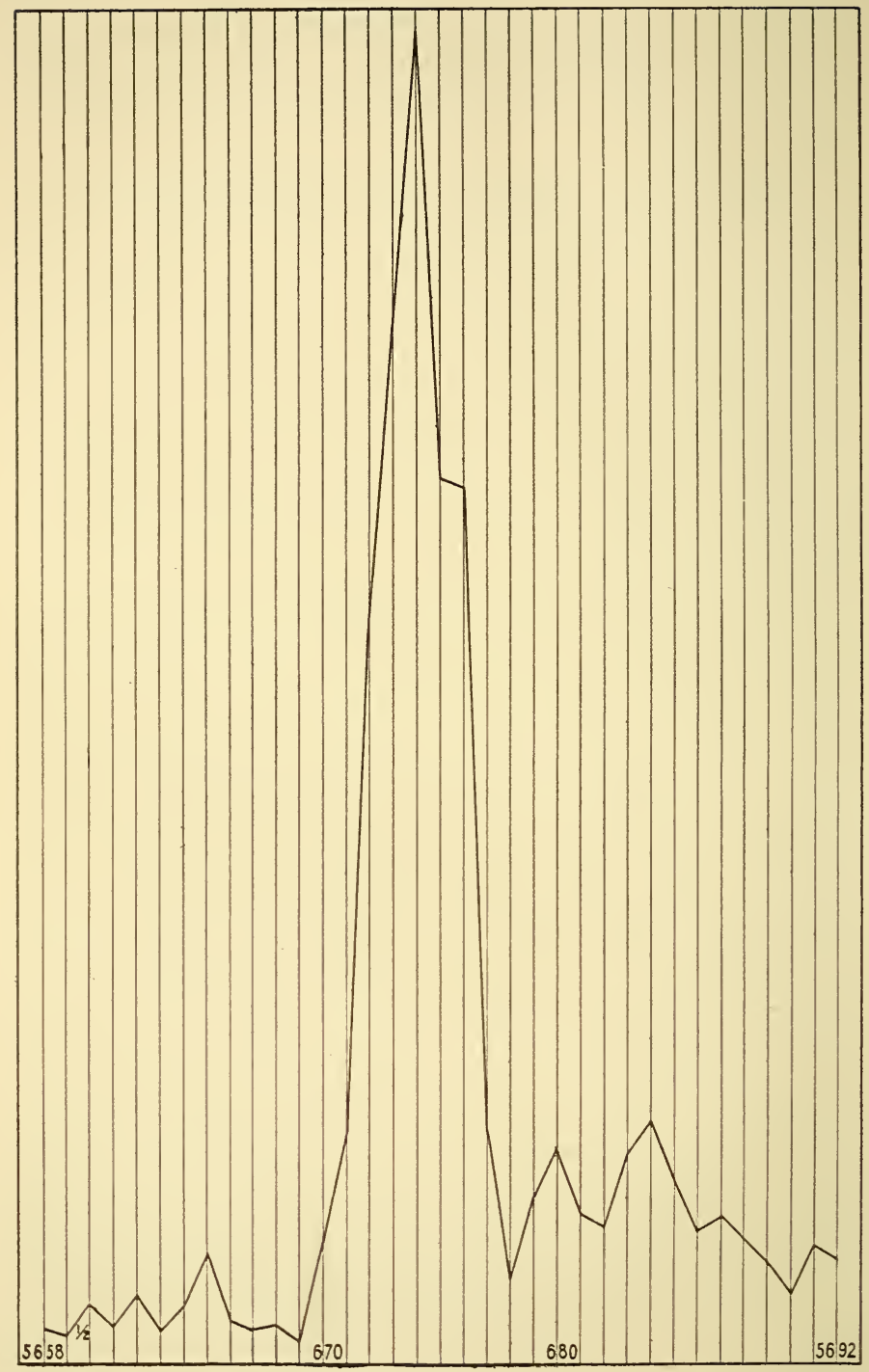

FIG. I8-Curve showing drainage during years $5671-5676$ recorded at locality $a$ Catskill, N. Y. It probably marks the first escape eastward, through the Mohawk, of the waters of the Great Lakes which occurred during the Lake Wayne stage. Observe the great thickness of the varves after the drainage. Scale, $1 / 2$ actual thickness. 
About 900 years after the readvance at Amherst, or during years $5671-5676$, there occurred a great drainage into glacial Lake Albany. Figure 18 and curve I4 (Pl. III) show it at Catskill, 65 miles below the then mouth of the Mohawk at Schenectady. It is registered at other localities up to Albany, but the zone is disturbed. It is the only drainage of importance into Lake Albany for more than 600 years during the ice retreat in the central and upper Hudson region. It records the sudden escape of a large quantity of water, which must have rushed across an abundance of easily eroded material. At the time of the drainage the ice edge stood somewhat south of Cohoes; and west of the Hudson, in all probability, it trended slightly north of west. The ice border may accordingly have left the highland south of the Mohawk River and the varves may record the drainage of a lake through the Mohawk Valley after the small waters, dammed in this valley, had escaped. These seem to have been too small and to have drained out through channels too short to allow them to pick up much material (see Fairchild, I912). The glacial lake in the Finger Lakes district discharged into the Mohawk waters and accordingly indirectly into Lake Albany (Fairchild, 1909, Pl. 37; 1912, Pl. 15). So it seems most likely that the drainage varves mark the first escape of the vast waters of the Great Lakes region which occurred during the stage known as Lake Wayne, the successor of Lake Whittlesey (Taylor, I9I3, p. 306; 1915, p. 386). This supposition is strongly supported by the fact that the varves above the drainage layer are much thicker than those beneath, the first twenty being two and a half times as thick. This shows that the new tributary to Lake Albany brought more material than was supplied by the glacial rivers discharging into the lake and by all other tributaries together.

Subsequent to this time of ice retreat the ice front readvanced and closed the outlet at Syracuse (Taylor, I915, pp. 392 and 398). The resulting stage in the Great Lakes region, Lake Warren, reached from the Finger Lakes district to the Huron basin and discharged westward. The eastern barrier of the lake is probably marked by the Niagara Falls moraine. This marked readvance 
of the ice very likely corresponded to the readvance at Claremont and Lake Winnepesaukee, N. H., which occurred about years 6200 to 6500 .

When the ice edge again withdrew, the outlet of the Great Lakes was shifted for the second time to the Mohawk Valley, and Lake Lundy came into existence (Taylor, I913, p. 309; 1915, p. 399 and 406 and Pl. 19; Fairchild, 1909, Pl. 40). The exact position of the ice barrier of the lake is not known, but it was between the Niagara escarpment and the present shore of Lake Ontario. The beaches of the lake have only moderate strength and indicate a transition stage. As the ice retired and lower outlets were uncovered, the waters fell, so that those over Lake Ontario became separated from those in the Erie basin. In the Ontario basin the transition stages to Lake Iroquois underwent a number of changes of level caused by slight retreats and readvances of the ice front (Taylor, I9I3, p. 310; 1915, p. 444). Finally the waters fell, owing to the opening of a lower outlet at Rome, and Lake Iroquois was established. This lake endured for a relatively long time. When the ice front had receded to the northern side of the Adirondacks, Lake Iroquois emptied into Lake Champlain, and the Rome outlet was abandoned (Peet, I904, p. 660). The lake level sank as the ice withdrew, and finally the sea, entering the submerged St. Lawrence Valley, changed the glacial lake into a marine gulf.

Before the marine stage could come into existence the ice had receded beyond the St. Lawrence River. The transition stages preceding Lake Iroquois and the lake itself, therefore, must correspond to the ice recession in northern New England and southeastern Canada. The pre-Iroquois oscillations of the ice border may correspond to the repeated readvances of the ice, which, as a reconnaissance study of the clays seems to show, occurred in the zone between St. Johnsbury and the Canadian frontier.

\section{Problems To Be Studied}

This inemoir only treats the main features of the recession of the last ice sheet in New England, while the details and a great 
many questions connected with these researches remain to be studied. Some of these problems may be pointed out.

On account of the great depth of the varve sediments the bottom layer was reached practically only in the northern part of the Connecticut Valley. It is, therefore, to be hoped that any opportunity to measure the lowest strata be used. Series with bottom varves are necessary for the determination of the exact rate of recession. If a sufficient number of sections with bottom can be secured, the position of the ice front for every winter can be mapped. Such a study has been carried out by De Geer (I912, Pl. 2; I9I2a, p. 464) of the Stockholm district. Detailed determination of the rate of recession probably yields the best material known for studying the long climatic periods, i.e. periods from a few decades to hundreds or thousands of years.

The zones of readvance of the ice should be studied in detail. The extent and number of oscillations, time involved, and the rate of retreat before and after the readvances are questions of great importance for the understanding of the causes. Stadial moraines should be sought and mapped particularly in these zones.

Determination of the length of time of the periods recorded by the stadial moraines which Taylor (1903) mapped in the Berkshires should be of great climatological interest (cf. p. 92).

Clay measurements in other lakes and valleys are very valuable for elimination from the normal curve of local, non-climatic features.

The history of the lakes presents interesting problems. A detailed study of their water levels is being made by Goldthwait. This will throw light upon the extension of the lakes (cf. p. 9), the sedimentation, the tilting of the land, tre changes of level of the lakes due to lowering or raising of their outlets (cf. pp. $8,5 \mathrm{I}$ ), and so forth. Determination of the minimum duration of the lakes by counting the varves will give an idea of the rate of the warping of the land.

The measured profiles represent a vast amount of material for the study of sedimentation. Part of this is given in the descrip- 


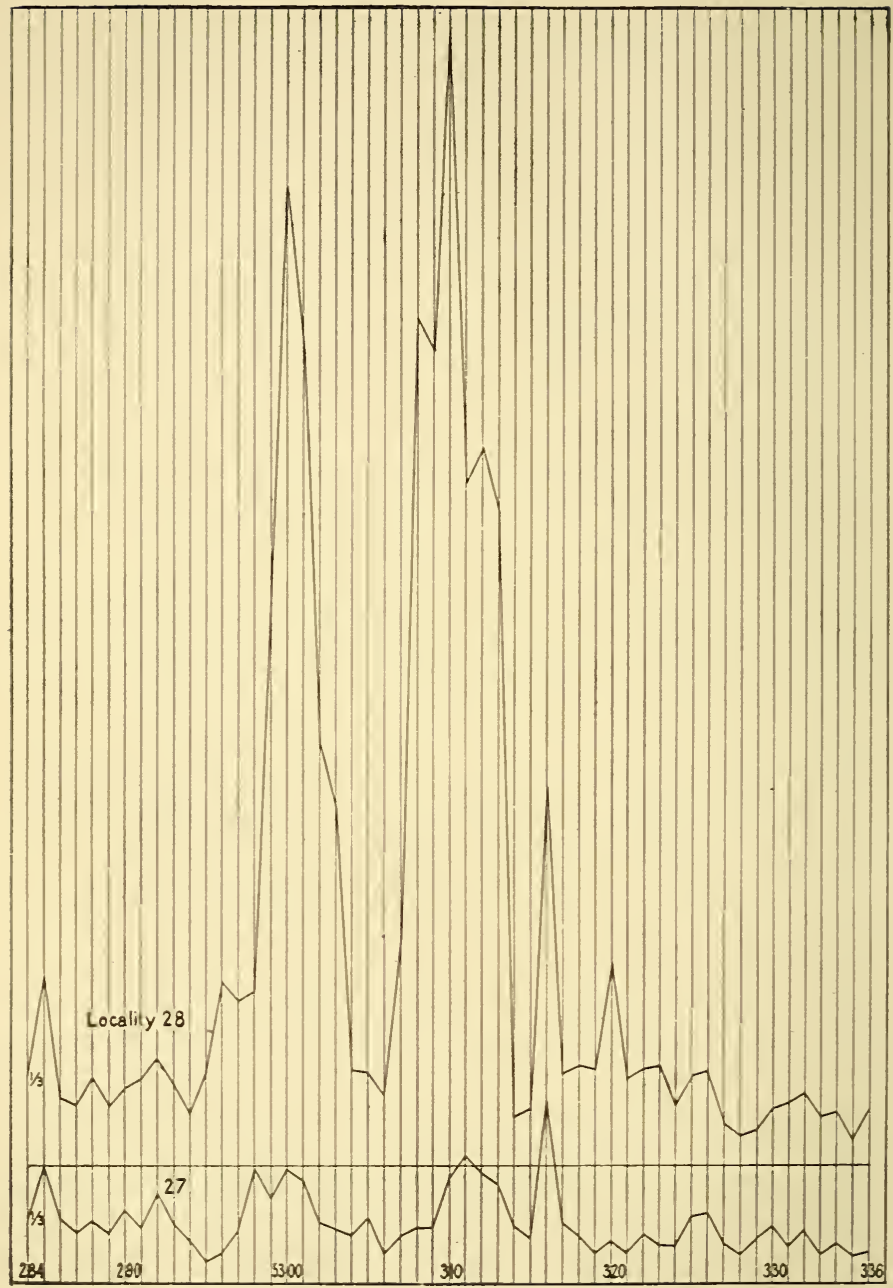

FIG. I9-Part of curves at localities 27 and 28 , near Greenfield, Mass., situated only 600 yards apart. The thick varves, at locality 28 , consist of coarse sand, often in lenses. Some varves at locality 27 are also sandy. The elevation of the localities is about the same. The current may have swept over locality 28 , but this does not seem to be a satisfactory explanation. Scale, $1 / 3$ actual thickness. 
tion of the sections (Ch. III). A closer treatment requires better knowledge of the surfaces of the lakes than we have now. Problems are: the spreading of the sediments in the lakes, i. e. the decreasing in thickness of the varves and in coarseness of the material outward from the mouth of the glacial river; sedimentation and depth of water (cf. Fig. I9 and pp. 5I, 69, 82); sedimentation and size of the drainage area; fluctuations in the sedimentation during the summer, as recorded in thick silty varves; the mechanical and chemical character of the sedimentsstudied in Sweden by Odén.

Drainages of lakes ponded by ice or by glacial deposits constitute a subject of interest for detailed study (cf. p. 69). So also do changes in the size of the drainage areas of the lakes, as the ice receded, and their relation to the sedimentation.

Driven southward by the ice, plants and animals re-immigrated to the newly exposed land. Hardy species followed closely the receding ice edge, and others came as fast as conditions became favorable for them. Remains of the earliest flora are preserved in the varve clays, and a stratigraphical study of them should be of both botanical and climatological interest. By measuring the varve series in which the plant remains occur and identifying these varves with the normal curve, the position of the ice edge, when the plants were embedded, can be fixed. Sandegren's (1915) study of the post-glacial flora and climate at Ragunda in northern Sweden, as recorded by the plant remains in the varve silts, is a standard work because of its accuracy. Of considerable interest are quantitative and stratigraphic studies of plant pollen in the clays, like those carried out in Sweden by $\mathrm{L}$. von Post and others.

The physiographic development and the geologic factors, such as erosion by rivers and by the sea, weathering, etc., can be studied under new conditions when the actual length of time since the release from the ice shall have become known. Knowing that southern New England was uncovered about 5,000 years earlier than the northern part, comparative studies can be made.

The question of local glaciers in the Adirondacks, Catskills, and White Mountains, after the departure of the ice sheet, might be settled by studies of the clays. 


\section{EXPLANATION OF THE MAP ILLUSTRATING THE RECESSION OF THE LAST ICE SHEET FROM NEW ENGLAND AND NEW YORK}

\section{By J. W. Goldthwait}

On this map (Pl. VI) have been assembled those observations of glaciation and of glacial recession which, so far as known to the compiler, appear trustworthy and useful as a background for plotting Dr. Antevs' data. It is fully realized that no complete and accurate map of the glaciation of this region can be made without much further field work. New York State, in the western Adirondacks and west and southwest of the Catskills especially, awaits fuller study. Unpublished work by Woodworth and by Alden in Massachusetts and by Rich in the Catskill region will doubtless make some correlations much clearer and more certain than those possible to show at this time.

The chief sources of information used are as follows. The titles of the publications referred to will be found, under the author's name and the year, in the List of References (pp. I08-II4).

\section{Direction of ice flow, as shown by striae and boulder dispersion}

In New Hampshire: C. H. Hitchcock (1878), J. W. Goldthwait and F. H. Foster (unpublished data on boulder dispersion).

In Vermont: C. H. Hitchcock (I86I) and scattered observations in more recent reports of the State Geologist by various investigators.

In Massachusetts: E. Hitchcock (I84I), B. K. Emerson (I898), and drumlin axes shown on topographic quadrangles of the U. S. Geological Survey.

In Rhode Island: N. S. Shaler (I889); also drumlin axes.

In Connecticut: W. W. Mather (I843), B. K. Emerson (I898), H. E. Gregory (I906), F. Ward (I920).

In New York: T. C. Chamberlin (I883), W. W. Mather (I843), J. F. Kemp and R. Ruedemann (I9IO), I. H. Ogilvie (I902), H. P. Cushing 
I907, I9I6), A. P. Brigham (I895), R. S. Tarr (I909), J. M. Clarke (IgII), W. J. Miller (I909, I9I0, I9I4, I9I6), H. L. Fairchild (I907), J. B. Woodworth (I90I, I905), J. L. Rich (I906, I9I4, I9I5), C. E. Gordon (I9I I), J. H. Stoller (I9I I, I9I6), H. J. Alling (I9I6), R. D. Salisbury and others (I902).

In New Jersey: R. D. Salisbury and others (I902, P1. 8; and I908), J. V. Lewis and H. B. Kümmel (IgI5).

In Pennsylvania: H. C. Lewis (I 884).

Because of lack of detailed information it generally has not been possible to discriminate between striae made at different stages of ice recession; hence, in compiling lines of flow, a ronservative attitude has been kept toward the delineation of minor lobes. In the Connecticut, Hudson, and Catskill regions these seem to have been more strongly accentuated than the map indicates, resembling perhaps the more thoroughly studied lobe of the Finger Lakes region. The very wide spread of the Mt. Ascutney boulder train is the best evidence of this. The flow of the ice appears to have been due southward, however, over the entire eastern uplands of Vermont, so that it is a mistake to regard the southward movement of ice down the Connecticut Valley as due in any sense to the presence of that valley.

\section{Terminal moraines}

In Massachusetts: J. B. Woodworth (I 897).

In New York: J. B. Woodworth (I90I), M. L. Fuller (I905, I9I4).

In New Jersey and Pennsylvania: same references as under former heading.

\section{Recessional moraines}

In Maine: F. J. Katz and A. Keith (I9I7).

In New Hampshire: J. W. Goldthwait (I9I6, and unpublished data). In Massachusetts and Rhode Island: J. B. Woodworth (I896, I 897), F. B. Taylor (I903), W. O. Crosby (I899).

In New York: T. C. Chamberlin (I883), F. Leverett (I9I5), R. S. Tarr (I909), H. L. Fairchild (I907), A. P. Brigham (I898), J. L. Rich (I906, I9I4, I9I5), F. B. Taylor (I913), C. E. Peet (I904), F. Carney (I909). 
Only a few of the more distinct lines of recession among those described in southern New England are shown. The "Newington moraine" of Katz and Keith is shown only in Maine because that part of it which lies in New Hampshire and Massachusetts seems to the compiler to consist of a series of local recessional wash plains and morainal embankments whose ice contacts lie in parallel lines which trend perpendicular to the striae. (The local moraines shown on Pl. VI in New Hampshire in the same axis are not a part of the "Newington moraine".) The lines of moraine in western New York are mapped in somewhat contradictory fashion by different investigators, making it difficult to select material consistently; but in the main these follow the courses determined by Leverett and Taylor.

\section{Isobases}

These are drawn only for southeastern New Hampshire and the adjacent part of Massachusetts, and are based upon detailed observations and measurements by the compiler. Tarr's 50 -foot beaches on Cape Ann are taken as the marine limit at that point. The absence of confirmatory evidence from the Salem-Boston district is puzzling; and the correct course of the isobases in Massachusetts is not known. Studies of the deformed water planes in the Merrimac, Connecticut, and Contoocook Valleys are in progress, but do not yet justify extension of the isobases farther inland than here shown. The probability that the "marine limits" at different localities are not even approximately contemporaneous makes a fuller construction of isobases unwise.

\section{Positions of receding ice edge}

These lines, plotted by Dr. Antevs after data collected by him at the localities shown, give, so far as the facts warrant, the distances uncovered by the receding ice edge each century in the valleys where observations are numerous. Three positions only are plotted in the Hudson Valley, to show how the recession 
there corresponds with that in New England. Dotted lines indicate the probable correlation of Antevs' ice border lines with Taylor's recessional moraines in the Berkshires and Rich's moraines in the Catskills, Peet's Glens Falls moraine south of Lake George, and the Great Lakes moraines as mapped by Taylor and Leverett. 


\section{LIST OF REFERENCES}

Alling, H. L. (I9I6). Glacial lakes and other glacial features of the central Adirondacks. Bull. Geol. Soc. of America, Vol. 27, I9I6, pp. $645-672$.

ANDERsSon, GunNar, AND Birger, Selim (IgI2). Den norrländska florans geografiska fördelning och invandringshistoria. Norrländskt Handbibliotek No. 5, I9I2. Upsala.

ANtevs, ERNSt (I9I5). Landisens recession i nordöstra Skåne. Geol. Fören. Förhandl., Vol. 37, I915, pp. 353-366. Stockholm.

ANTEVS, ERNST (I922). On the late-glacial and post-glacial history of the Baltic. Geogr. Review, Vol. I2, No. 4, Oct. I922.

BARRELL, JoSEPH (I9I5). Factors in movements of the strand line and their results in the Pleistocene and post-Pleistocene. Amer. Journ. of Sci., Ser. 4, Vol. 40, I915, pp. I-22.

Birger, Selim (I9I2). See ANdersson, Gunnar (IgI2).

BRIgham, A. P. (I895). Drift bowlders between the Mohawk and Susquehanna Rivers. Amer. Journ. of Sci., Ser. 3, Vol. 49, 1895, pp. 2 I8-228.

BrighaM, A. P. (I898). Topography and glacial deposits of Mohawk Valley. Bull. Geol. Soc. of America, Vol. 9, I898, pp. 183-210.

BRÜCKNER, EDUARD (I 890). Klimaschwankungen seit I700 nebst Bemerkungen über die Klimaschwankungen der Diluvialzeit. Geogr. Abhandl. herausg. von A. Penck, Vol. 4, I890, No. 2. Vienna.

BRÜCKNER, EdUARD (I92I). Geochronologische Untersuchungen über die Dauer der Postglazialzeit in Schweden, in Finnland und in Nordamerika. Zeitschr. für Gleischerkunde, Vol. I2, I92 I, pp. 39-57.

CARLzON-CALDENIUS, CARL (I9I3). Inlandisens recession mellan Bispgården och Stugun i Indalsälvens dalgång i Jämtland. Geol. Fören. Förhandl., Vol. 35, I9I3, pp. 3 II-328 and 348-360. Stockholm.

CARNey, Frank (I909). The Pleistocene geology of the Moravia quadrangle, New York. Bull. Scientific Laboratory of Denison Univ., Vol. I4, I909, pp. 335-442.

Chamberlin, T. C. (I883). Terminal moraine of the Second Glacial Epoch. 3rd Ann. Rept. U. S. Geol. Survey, for I881-82, pp. $291-402$. Washington, D. C. I883.

ClaRke, J. M. (IgII). Seventh Report of the Director of the Science Division, New York State Museum Bull. No. I49, I9II.

CRosby, W. O. (I899). Geological history of the Nashua valley during the Tertiary and Quaternary periods. Technology Quarterly, Vol. I3, I890, p. 322. Massachusetts Institute of Technology. Boston. 
Cushing, H. P. (I907). Geology of the Long Lake quadrangle. New York State Museum Bull. No. I15, 1907.

Cushing, H. P. (IgI6). Geology of the vicinity of Ogdensburg. New York State Museum Bull. No. I9I, I9I6.

Cushing, H. P.; Fairchild, H. L.; Ruedemann, Rudolf; and Smyth, C. H., Jr. (IgIO). Geology of the Thousand Islands region. New York State Museum Bull. No. 145, I910.

DANA, J. D. (I870). On the geology of the New Haven region, with special reference to the origin of some of its topographical features. Trans. Connecticut Acad. of Arts and Sci., Vol. 2, Part I, I870, pp. 45-II2. New Haven.

De Geer, Gerard (I 882). Om en postglacial sänkning i södra och mällersta Sverige. Geol. Fören. Förhandl., Vol. 6, I 882, pp. I49-I62; reference on p. I59. Stockholm.

De Geer, Gerard (I884). Om möjligheten af att införa en kronologi för istiden. Geol. Fören. Förhandl., Vol. 7, 1884, p. 3. Stockholm.

De Geer, Gerard (1885). Om istidens kronologi. Geol. Fören. Förhandl., Vol. 7, 1885, pp. 512-5I3. Stockholm.

De Geer, Gerard (I9I2). A geochronology of the last i2,000 years. Compte Rendu Congrès Géol. Internatl. à Stockholm, I9Io, pp. 24I-253. Stockholm, I9I2.

De Geer, Gerard (I9I2a). Geochronologie der letzten I2,000 Jahre. Geol. Rundschau, Vol. 3, I9I2, pp. 457-47I. Leipzig.

De Geer, Gerard (I9I4). Om naturhistoriska kartor över den baltiska dalen. Pop.-Naturvet. Revy, I9I4, pp. I89-200. Stockholm.

De Geer, Gerard (I92I). Correlation of late glacial clay varves in North America with the Swedish time scale. Geol. Fören. Förhandl., Vol. 43, I92I, pp. 70-73. Stockholm.

De Geer, Gerard (I92Ia). Nordamerikas kvartärgeologi belyst av den svenska tidskalan, Geol. Fören. Förhandl., Vol. 43, I92 I, pp. 497-499. Stockholm.

DilleR, J. S. (1898). The geology of Westfield and vicinity, in EMERSON, B. K. (I 898), pp. $654-656$.

Douglass, A. E. (I9I9). Climatic cycles and tree-growth. Carnegie Instn. Publ. No. 289, Washington, D. C., I9r9.

Emerson, B. K. (1887). The Connecticut Lake of the Champlain period, north of Holyoke. Amer. Journ. of Sci., Ser. 3, Vol. 34, I887, p. 404 .

Emerson, B. K. (I898). Geology of Old Hampshire County, Mass., comprising Franklin, Hampshire, and Hampden Counties, U. S. Geol. Survey Monograph 29, 1898.

Emerson, B. K. (I898a). Holyoke Folio. U. S. Geol. Survey Geologic Atlas, Folio No. 50, 1898. 
FAIRCHILD, H. L. (I907). Drumlins of central western New York. New York State Museum Bull. No. III, I907.

FAIRChILD, H. L. (I909). Glacial waters in central New York. New York State Museum Bull. No. 127, 1909.

Fairchild, H. L. (Igio). See Cushing, H. P., and others (I9Io).

FAIRChILD, H. L. (I9I2). The glacial waters in the Black and Mohawk valleys. New York State Museum Bull. No. I6o, I9I2.

FAIRCHILD, H. L. (I9I4). Pleistocene marine submergence of the Connecticut and Hudson valleys. Bull. Geol. Soc. of America, Vol. 25, I9I4, pp. 63 and 2 I9-242.

Fairchild, H. L. (I9I9). Post-glacial uplift of southern New England. Bull. Geol. Soc. of America, Vol. 30, 1919, pp. 597-636.

Fuller, M. L. (1905). Geology of Fishers Island, New York. Bull. Geol. Soc. Amer., Vol. I6, I905-06, pp. 367-390.

Fuller, M. L. (I9I4). The geology of Long Island, New York. U. S. Geol. Survey Professional Paper 82, I9I4.

Goldthwait, J. W. (I9I6). Glaciation in the White Mountains of New Hampshire. Bull. Geol. Soc. of America, Vol. 27, I9I6, pp. 263294.

Gordon, C. E. (I9II). Geology of the Poughkeepsie quadrangle. New York State Museum Bull. No. I48, I9II.

Gregory, H. E. (I906). Glacial geology, in Manual of the geology of Connecticut, Connecticut State Geol. and Nat. Hist. Survey Bull. 6, pp. 223-259, I906.

Hager, K. D. (i86i). See Hitchcock, Edward, and others (i86I).

HaNn, Julius (I9II). Klima der gemässigten Zonen und der Polarzonen, in Handbuch der Klimatologie, Vol. 3, Part 2. Stuttgart, I9II.

Hitchсоск, C. H. (I86I). See Hitchсоск, Edward, and others (I86I).

Нiтcнсоск, C. H. (I878). Atlas accompanying the report on the geology of New Hampshire. New York, I878.

HitchCock, Edward (I84I). Final report on the geology of Massachusetts, Vol. 2, pp. 350-422. Amherst, I84I.

Hitchсock, Edward; Hitchcock, Edward, Jr.; Hager, A. D.; AND Hiтchсоск, C. H. (I86I). Report on the geology of Vermont, descriptive, theoretical, economical, and scenographical. 2 vols., Claremont, N. H., I86I.

Hitchcock, Edward, JR. (I86I). See Hitchcock, Edward, and others (I86I).

Новвs, W. H. (I9II). Characteristics of existing glaciers. New York, I9II.

Hoвbs, W. H. (I9IIa). The Pleistocene glaciation of North America viewed in the light of our knowledge of existing continental glaciers. Bull. Amer. Geogr. Soc., Vol. 43, I9I I, pp. 64I-659. 
НоввS, W. H. (I9I5). The rôle of the glacial anticyclone in the air circulation of the globe. Proc. Amer. Philos. Soc., Vol. 54, I9I5, pp. I85225. Philadelphia.

Huntington, Ellsworth (I9I4). The climatic factor as illustrated in arid America. Carnegie Instn. Publ. I92. Washington, D. C., I9I4.

KAtZ, F. J., AND KeIth, A. (I9I7). The Newington moraine, Maine, New Hampshire, and Massachusetts. U. S. Geol. Survey Professional Paper I08b, I9I7.

KeIth, A. (I9I7). See Katz, F. J. (I9I7).

Kemp, J. F., ANd Ruedemann, Rudolf (I9io). Geology of the Elizabethtown and Port Henry quadrangles. New York State Museum Bull. No. I38, I910.

Kindle, E. M. (I9I3a). See Taylor, F. B. (I9I3a).

KNapp, G. N. (Ig02). See Salisbury, R. D., and others (IgO2).

KÜnnel, H. B. (I902, I902a, I9I5). See Salisbury, R. D., and others (I902 and I902a) and LEWIS, J. V. (I9I5).

LeVerett, Frank, ANd TAYLoR, F. B. (I9I5). The Pleistocene of Indiana and Michigan and the history of the Great Lakes. U.S. Geol. Survey Monograph 53, I9I5.

LEwIS, H. C. (I884). Report on the terminal moraine in Pennsylvania and western New York. 2nd Geol. Survey of Pennsylvania, Rept. of Progress $Z$, I884.

Lewis, J. V., AND Kümmel, H. B. (I9I5). The geology of New Jersey. Geol. Survey of New Jersey Bull. I4, I9I 5 .

LIDÉN, RAGNAR (I9II). Om isafsmältningen och den postglaciala landhöjningen i Ångermanland. Geol. Fören. Förhandl., Vol. 33, I9II, pp. 27I-280. Stockholm.

LIDÉN, RAGNAR (I9I3). Geokronologiska studier öfver det finiglaciala skedet i Ångermanland. Sveriges Geol. Undersökning, Ser. Ca, No. 9, I9I3. Stockholm.

LotGhlin, G. F. (1905). The clays and clay industry of Connecticut. Connecticut State Geol. and Nat. Hist. Survey Bull. 4, 1905.

Mather, W. W. (I843). Geology of the First Geological District, in Geology of New York, Part I, pp. I58-228. Albany, I843.

Miller, W. J. (I909). Geology of the Remsen quadrangle. New York State Museum Bull. No. I26, I909.

Miller, W. J. (Igro). Geology of the Port Leyden quadrangle, Lewis County, N. Y. New York State Museum Bull. No. I35, I9Io.

Miller, W. J. (I9I4). Geology of the North Creek quadrangle, Warren County, New York. New York State Museum Bull. No. I7o, I9I4.

Miller, W. J. (I9I6). Geology of the Lake Pleasant quadrangle, Hamilton County, New York. New York State Museum Bull. No. I82, I916.

Miller, W. J. (I9i6a). Geology of the Blue Mountain, New York, quadrangle. New York State Museum Bull. No. 192, I916. 
ODÉN, Sven (I9I8). Automatisch registrierbare Methode zur mechanischen Bodenanalyse. Bull. Geol. Inst. Upsala, Vol. I6, pp. I5-64, I9I8. ODÉN, Sven (I9I9). Über die Vorbehandlung der Bodenproben zur mechanischen Analyse. Bull. Geol. Inst. Upsala, Vol. I6, pp. I25-I34, I9I9.

Odén, Sven, And Reuterskiöld, A. (I9I9a). Zur Kenntnis des Ancylustons. Bull. Geol. Inst. Upsala, Vol. I6, pp. I35-158, I9I9.

OdÉn, Sven (I920). Die automatisch registrierende Apparatur zur mechanischen Bodenanalyse und einige damit ausgeführte agrogeologische Untersuchungen. Internatl. Mitt. für Bodenkunde, I920, pp. 30I-342. Berlin.

OGILvie, I. H. (I902). Glacial phenomena in the Adirondacks and Champlain valley. Journ. of Geol., Vol. I0, I902, pp. 397-4I 2.

Peet, C. E. (I902, I902a). See Salisbury, R. D., and others, (I902, I902a).

Peet, C. E. (I904). Glacial and post-glacial history of the Hudson and Champlain valleys. Journ. of Geol., Vol. I2, I904, pp. 415-469 and 6I 7-66I.

von Post, Lennart (I9II). En exakt geologisk tideräkning. Pop.Naturvet. Revy, I9II, pp. II-20. Stockholm.

VON POST, LenNart (I9I6). Om skogsträdpollen i syd svenska torvmosseföljder. Geol. Fören. Förhandl., Vol. 38, I9I6, pp. 384-394. Stockholm.

Reuterskiöld, A. (I9Iga). See Odén, Sven (IgIga).

Rich, J. L. (I906). Local glaciation in the Catskill Mountains. Journ. of Geol., Vol. I4, I906, pp. II3-I2I.

Rich, J. L. (I9I4). Divergent ice-flow on the plateau northeast of the Catskill Mountains as revealed by ice-molded topography. Bull. Geol. Soc. of America, Vol. 25, I9I4, pp. 68-70.

RICH, J. L. (I9I5). Notes on the physiography and glacial geology of the northern Catskill Mountains. Amer. Journ. of Sci., Ser. 4, Vol. 39, I9I5, pp. I37-I66.

Ruedeman, Rudolf (igio, igioa). See Kemp, J. F. (igio), and Cushing, H. P. (I9Io).

Salisblry, R. D., Künmel, H. B., Peet, C. E., and Knapp, G. N. (Ig02). The glacial geology of New Jersey. Final Report of the Geological Survey of New Jersey, Vol. 5, I902.

Salisblry, R. D., Künmiel, H. B., and Peet, C. E. (Ig02a). New Iork City Folio. U. S. Geol. Survey Geologic Atlas, Folio No. 83, 1902.

S.tlisbury, R. D. (I908). Quaternary System, Passaic Folio, N. J.-N. Y., U. S. Geol. Survey Geologic Atlas, Folio No. I57, I908, p. I4.

SANDEGREN, R. (I9I5). Ragundatraktens postglaciala utvecklingshistoria enligt den subfossila florans vittnesbörd. Sveriges Geol. Undersökning, Ser. Ca, No. I2, I9I5. Stockholm. 
Salramo, Matti (I9I8). Geochronologische Studien über die spätglaziale Zeit in Südfinnland. Bull. Comm. Géol. de Finlande No. 5o, I9I8; also Fennia, Vol. 4I, No. I, pp. I-44, Helsingfors, I9I8.

SAYLES, R. W. (I9I9). Seasonal deposition in aqueo-glacial sediments. Memoirs Museum of Comp. Zoöl., Vol. 47, No. I. Cambridge, Mass., I9I9.

SAyles, R. W. (1922). The dilemma of the paleoclimatologists. Amer. Journ. of Sci., Ser. 5, Vol. 3, I922, pp. 456-473.

ShAlER, N. S. (I889). The conditions of erosion beneath deep glaciers, based upon a study of the boulder train from Iron Hill, Cumberland, R. I. Bull. Museum of Comp. Zoöl., Vol. I6, I889, pp. 185-225. Cambridge, Mass.

SiIth, Alfred (1832). On the water courses and the alluvial and rock formations of the Connecticut River valley. Amer. Journ. of Sci. and Arts, Vol. 22, I832, pp. 205-231.

Siryth, C. H., Jr. (I9ro). See Cushing, H. P., and others (I9Io).

Stoller, J. H. (IgII). Glacial geology of the Schenectady quadrangle. New York State Museum Bull. No. I54, I9II.

Stoller, J. H. (IgI6). Glacial geology of the Saratoga quadrangle. New York State Museum Bull. No. I83, I916.

TARR, R. S. (I903). Post-glacial and inter-glacial changes of level at Cape Ann, Mass., with a note on the elevated beaches by J. B. Woodworth. Bull. Museum of Comp. Zoöl., Vol. 42, 1903, pp. I8I-196. Cambridge, Mass.

TARr, R. S. (I909). Watkins Glen-Catatonk Folio. U. S. Geol. Survey Geologic Atlas, Folio No. I69, I909.

TAYLOR, F. B. (I894). The limit of postglacial submergence in the highlands east of Georgian Bay. Amer. Geologist, Vol. I4, I894, pp. 273-289.

TAYLOR, F. B. (I903). The correlation and reconstruction of recessional ice borders in Berkshire County, Mass. Journ. of Geol., Vol. II, I903, pp. $323-364$.

TAYLOR, F. B. (I9I3). The glacial and postglacial lakes of the Great Lakes region. Ann. Rept. Smithsonian Instn. for I9I2, pp. 29I-327.

Tayzor, F. B., And Kindle, E. M. (rgiza). Niagara Folio. U. S. Geol. Survey Geologic Atlas, Folio No. I90, I913.

Taylor, F. B. (I9I5). See LeVerett, Frank, and Taylor, F. B. (I9I5). Upham, Warren (1878). Modified drift, in C. H. Hitchcock: Geology of New Hampshire. Concord, N. H., I878.

UPHAM, WARREN (I888). The geology of Carver and Scott Counties, in The Geology of Minnesota, Final Report, Vol. 2, pp. 102-147, Geol. and Nat. Hist. Survey of Minn. I888.

WARD, FREEIAN (I920). The Quaternary geology of the New Haven region, Connecticut. Connecticut State Geol. and Nat. Hist. Survey Bull. 29, I920. 
Woodworth, J. B. (I896). The retreat of the ice-sheet in the Narragansett Bay region. Amer. Geologist, Vol. I8, I896, pp. I50-I68.

Woodworth, J. B. (I897). Some glacial wash-plains of southern New England. Bull. Essex Inst., Vol. 29, I897. Salem, Mass.

Woodworth, J. B. (I90I). Pleistocene geology of portions of Nassau County and Borough of Queens, New York State Museum Bull. No. 48 , I90I.

WOODWORTH, J. B. (I903). See TARr, R. S. (I903).

Woodworth, J. B. (I905). Pleistocene geology of Mooers quadrangle. New York State Museum Bull. No. 83, 1905.

Woodworth, J. B. (I905a). Ancient water levels of the Champlain and Hudson valleys, New York State Museum Bull. No. 84, I905. 
INDEX 



\section{INDEX}

Adirondack Mountains, 95, I00, I03, I04

Agassiz, Louis, vii

Albany, N. Y., 46, 99

Albany, glacial Lake, 99

Alden, Mr., I04

Alden moraine, 97

American Geographical Society, xii, xiii; photostat copies of the normal curve, 48

Amherst, Mass., 53, 66, 93; clay pits, I8; section showing till and partially folded clay (diagr.), 77

Amherst-Northampton region, oscillations of ice border, 77

Ann, Cafe, Io6

Arkona, glacial Lake, 97

Arthur Kill, 7

Ascutneyville, Vt., bluff, 28

Ashuelot River, I9

Baltic region, $8,85,86$

Bear Island, 85

Bellows Falls, Vt., lake, 82; localities studied near, 20, 2I, 22

Berkshires, 92, 94, 96, 107

Bethlehem, N. H., 83, 95

Bibliography, I08

Blackmount station, N. H., 3 I

Blekinge, 90

Boscawen, N. H., railroad cut, 27

Boston, 9, 94

Bottom varves, IOI

Boulder dispersion, sources of information, I04

Bow Junction, N. H., 23

Boyce station, N. H., 25

Bradford, Vt., bluff, 30

Brattleboro, Vt., brickyard, I9

Brückner, Eduard, 88, 93

Buffalo, N. Y., 97

Calving, 86, 87

Canterbury station, N. H., clay pit, 27

Catskill, N. Y., 46; drainage curve, 98 (diagr.), 99

Catskill Mountains, 95, 97, I03, I04, I07

Chamberlin, T. C., 95
Champlain, Lake, Ioo

Charlestown, N. H., river bluffs, 2 I, 22

Charter Oak Park, near Hartford, Conn., I I

Chicopee, Mass., brickyard clay pits, I3, I4

Chronology, normal curve and absolute time, 48

Claremont, N. H., 47, 74, 79, 8I, 93, 95, Ioo; localities studied near, 22, 28

Claremont Junction, N. H., clay pit, 23

Clay, disturbances in, 72; type of clay and rate of retreat, 84 . See also Varves

Clay Brook, N. H., bluff, 30

Clay Point, near Wolfeboro, N. H., 8 I

Climate, during recession, 89; Sweden and New England, 90

Climatic periodicity, 9I

Coeymans, N. Y., 46

Cohoes, N. Y., 46, 95, 99

Concord, N. H., 95; abnormal varves, 69 ; lake, 82 ; localities studied near, $23,24,25,26,27$

Conicut station, Vt., ravine, 3 I

Connecticut River, junction with Passumpsic River, 34, 35, 6I, 66; oxbow, I 7

Connecticut Valley, correspondences of varve curves with Merrimac and Hudson Valleys, 67; localities studied, II, 28; maps showing localities studied, 37-44

Connections, 64

Correspondences, 67

Coxsackie, N. Y., 46

Crowfoot Brook, I4

Curves. See Normal curve, Varve curves

Cycles, climatic, 92

De Geer, Gerard, viii, 3, 84, I0I; Hudson Valley ice recession, 46; New England and Sweden ice retreat, 48; temperature studies, 85 ; time scale, xi, 4; Wells River, Vt., and Woodsville, N. H., 32

Disturbances in the clay, 72

Douglass, A. E., 92 
Drainage varves, 69

Drainages, 70 ; three drainages into the Connecticut River above its junction with the Passumpsic, 70,7 I

East Putney, Vt., railroad cut, 20

East Ryegate, Vt., ravine and blufis, 34

East Windsor Hill, Conn., I3

Easthampton, Mass., I6

Emerson, B. K., 3, 9, 37, 5I, 80, 89, 95

Erie, Lake, basin, 97, 100

Fairchild, H. L., 9

Fauna, 89

Fenno-Scandia, 9, 49, 84, 87, 90, 93

Finger Lakes district, 95, 97, 99

Finland, $79,86,87$; rate of ice retreat, 92 (diagr.), 93

Fisher's Island, 8

Flora, I03; Northampton varve clay, 89; Sweden, 90

Forest Park, near Springfield, Mass., I3

Fort Hill station, N. H., railroad cut, I9

Franklin, N. H., clay pit, 27

Genesee River, 97

Glacial lakes. See Lakes

Glacial rivers, I, 9

Glacial theory, vii

Glaciers, local, I03

Glens Falls, I07

Goldthwait, J. W., xii, 9, 8I, 84, 95, IOI; explanation of map (PI. VI), I04; map of ice retreat, 94; Preface, vii

Great Lakes region, correlation of ice retreat with that of New England, 95; first escape of waters, 98, 99; moraines, 107

Greenfield, Mass., brickyards, IS; part of curves (diagr.), I02; reliability of varves, 54

Grout station, Vt., localities studied near, 20

Hackensack, N. J., $\bar{i}, 8$

Hadley, Mass., I 7

Hampshire Brick Co., I5

Hanover, N. H., 83; localities studied near, 29, 30; thick drainage varve, 70

Hartford, Conn., brickyards, II, I2, I3; reliability of varves, 49; varve number, 49
Haverhill station, N. H., ravines studied near, 30, 3 I

Hinsdale, N. H., 55

Hitchcock, C. H., 9, 37, 45

Hitchcock, Edward, vii, 3

Hobbs, W. H., 86

Holyoke, Mass., brickyards, I4, I5

Holyoke Brick Co., I4

Holyoke Range, 52, 66

Hookset, N. H., 23

Hudson, N. Y., 46, 96

Hudson River, elevation of lower district, 9

Hudson Valley, 55, 83, 99, I06; correspondences with Connecticut and Merrimac Valleys, 67; localities used, 46

Huron, Lake, basin, 99

Ice border, oscillations, $77,8 \mathrm{I}$; rate of retreat, 75

Ice flow, direction, sources of information, I04

Inwood, Vt., 93; localities studied, 35 , 36

Iroquois, Lake, Ioo

Isobases, I06

Jackson, C. T., vii

Jeffrey, E. C., 90

Keene, N. H., brickyard, I9

Kingston, N. Y., 97

Lake sediments, 9

Lakes, formation of ice front, 9; glacial lakes outlines in Connecticut and Merrimac Valleys (maps), 37-45; problems, IoI; White Mountains, $7 \mathrm{I}, 72$

Late glacial time, deînition,xi

Leverett, Frank, 96, 107

Lidén, Ragnar, viii, xi; Wells River and Woodsville samples, 32

Little Sugar River, bluff, 22

Littleton, N. H., 83

Localities studied, II

Long Island, 8

Long Island Sound, 8

Loughlin, G. L., 9, 37

Lundy, Lake, Ioo

Lynch Brickyard, I4 
Map illustrating the recession, opp. I20; explanation, I04

Marine clays, 3

Mascoma River, 29, 58

Mather, W. W., vii

Mathews, E. B., xii

Measuring clay layers (ill.), opp. 5

Merrimac Valley, 82; correspondences of varve curves with Connecticut and Hudson Valleys, 67; localities studied, 23; map of localities studied, 45 ; reliability of varves, 56

Middletown, Conn., 52

Mink Brook, N. H., 29

Mohawk River, 46

Mohawk Valley, 83, 95, 99, I00

Montague City, Mass., brickyards, I8, I9

Moraines, Berkshires, 92; Great Lakes region, 96; sources of information, I05

Narrows, the, 7

National Research Council, xii

Nevel's Brickyard, I2

New England, abundance and quality of material, 65 ; conditions during deposition of the varve clay, 7 ; southern, higher elevation in late glacial time, 7

New Haven, Conn., 7, 8

New York (city), 7

New York (state), 95, 96

Newbury, Vt., clay pits, 3 I

Newington moraine, Io6

Niagara Falls, 97, 99

Normal curve, opp. I20; absolute time and, 48 ; method of construction, 47 ; symbols explained, 48

North Charlestown, N. H., 22

Northampton, Mass., 66, 95; brickyards, I6, I 7; flora in varve clay, 89; part of curves (diagr.) 78; reliability of varves, 53. See also AmherstNorthampton region

Northboro station, N. H., clay pit, 30

Northeastern States, previous knowledge of ice retreat, 94

Odén, Sven, I03

Ontario, Lake, I0o

Ontario, Lake, basin, 95
Oscillations of ice border, AmherstNorthampton region, 77; Lake Winnepesaukee region, $8 \mathrm{I}$

Oxbow of Connecticut River, I7

Park Brickyard, I I

Passumpsic, Vt., slide, 36

Passumpsic River, junction with Connecticut River, 34, 35, 6I, 66

Passumpsic Valley, 66, 83

Pecowsic Brook, I3

Peet, C. E., I07

Pembroke, N. H., 23

Penacook station, N. H., 26

Periodicity, climatic, 9I

Peripheral land, rising of, 8

Plants, pollen in clays, I03. See also Flora

Podunk River, I2

Port Huron morainic system, 97

Post, Lennart von, IO3

Post-glacial time, definition, xi

Precipitation, $85,86,87$

Previous knowledge of ice retreat, 94

Problems to be studied, Ioo

Putney, Vt., brickyard, I9

Ragunda, xi, 90; flora and climate, I03

Rainfall, $85,86,87$

Rate of recession, 74,90

Recession, conditions controlling, 85; previous knowledge, 94 ; rate, 74 , 90; rate in middle zone, $8 \mathrm{I}$; rate in northern zone, 83 ; rate in southern zone, 76 ; rate of retreat and type of clay, 84

References, I08

Rich, J. L., 95, IO4, IO7

Rome, N. Y., Ioo

St. Johnsbury, Vt., 83, I00; slide near, 36

St. Lawrence Valley, Ioo

Salpausselkä, 87, 93

Sandegren, R., I03

Sauramo, Matti, 79, 88, 92, 93

Sayles, R. W., xii, xiii, 90

Schenectady, N. Y., 99

Sedimentation problems, IOI, I03

Sediments, 9

Simon Lake, Quebec, varve clay (ill.), opp. 4 
Smith. Alfred, 3

South Hadley, Mass., I 5

South Hadley Falls, Mass., I4

South Windsor, Conn., I2

Spitsbergen, 85

Springfield, Mass., brickyards, I3; reliability of varves, 49

Stockholm, I or

Stockport, N. Y., 46

Stony Brook, South Hadley, Mass., I5

Stoughton's Brook, I3

Striae, sources of information, I04

Sugar Ball Bluff, N. H., 25

Sugar River, 28

Suncook, N. H., 23

Suncook River, late glacial, 57

Superior, Lake, 87

Sverige Amerika Stiftelsen, xii

Sweden, flora, 90; ice retreat, xi; ice retreat as compared with New England, 48; rate of ice retreat, 90; temperature, 85,86

Syracuse, N. Y., 97, 99

Tarr, R. S., 106

Taylor, F. B., 3, 92, 95, 96, 107

Temperature, 85,89 . See also Climate

Topography, influence on rate of recession, 87

Turners Falls, Mass., brickyard, I9

Upham, Warren, 3, 81, 82, 95

Utica, N. Y., 97

Varve clay, formation, I; manner of deposition (ill.), 2; method of investigation, 3

Varve curves, agreement from widely: separated localities, 67; examples illustrating agreement, 65
Varve studies, bearing on previous work, 94; confirmations, 95; contribution to the problem of glacial correlation of Great Lakes region and New England, 96; future problems, Ioo

Varves, abnormal, 69; abnormally thick, 69; bottom, IOI; connections, 64 ; definition, xi, 3 ; drainage varves, 69; exposure of varve clay (ill.), opp. 4; measuring, 4, opp. 5 (ill.); New England, character, 65; reliability of those measured, discussion by groups, 49 ; thickness, meaning of, 72 ; value for study, 64

Walker Brook, 28

Warren, Lake, 97, 99

Wayne, Lake, 98, 99

Weirs, N. H., 8I

TTells River, Vt., De Geer's locality, 32; localities studied near, 3 I

Westboro, N. H., localities studied near, 29

Westfield, Mass., brickyard clay pits, I5, I6

Westminster station, Vt., slide and bluff near, 2 I

White Mountains, 95, I03; ice-ponded lakes, $7 \mathrm{I}, 72$

White River, 58, 68, 83

White River Junction, Vt., ravine, 29

Whittlesey, Lake, 97, 99

Willimansett, Mass., If

Wilson, Conn., I 2

Windsor, Vt., bluff near, 28

Vinnepesaukee, Lake, 95, I00; oscillations of the ice border in the region, $8 \mathrm{I}$

Wolfeboro, N. H., 8I

Woodsville, N. H., Io, 84; De Geer's locality, 32; localities studied near. $30,31,32,33,34$; reliability of varves, 59,60

Woodworth, J. B., 9, I04 


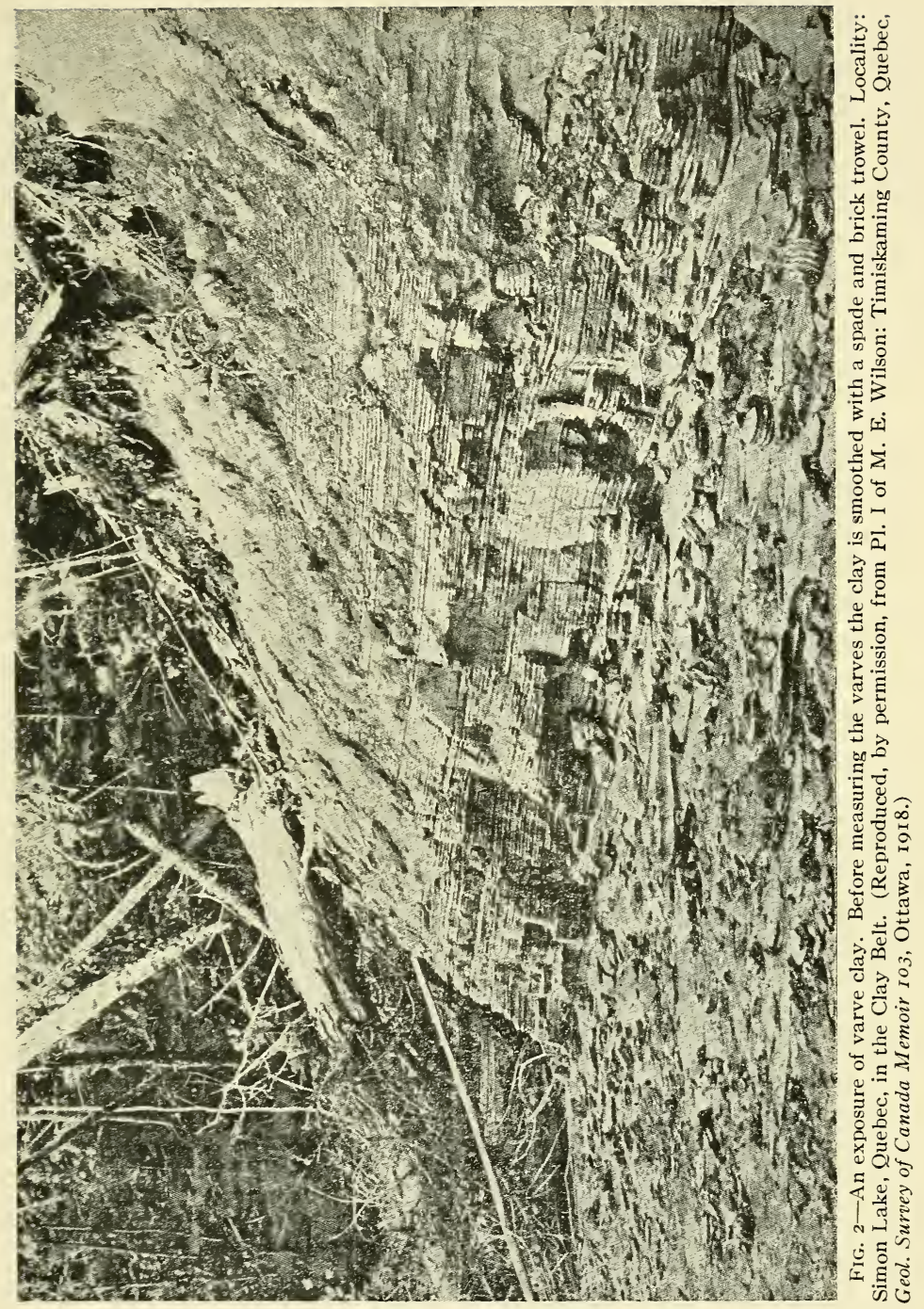




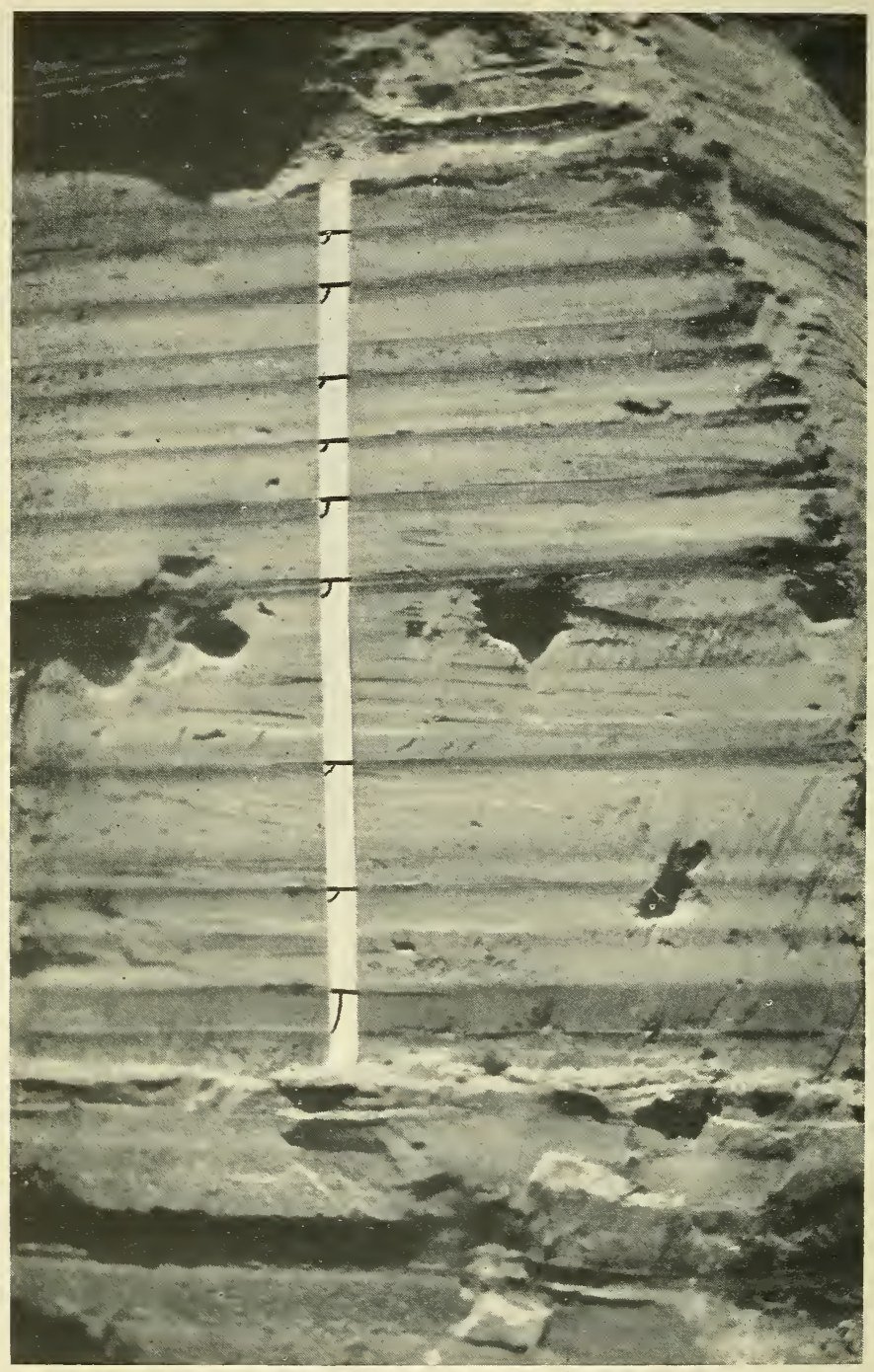

FIG. 3-View showing the method of measuring the clay lavers on a strip of paper. Locality 67, Hanover, N. H. 



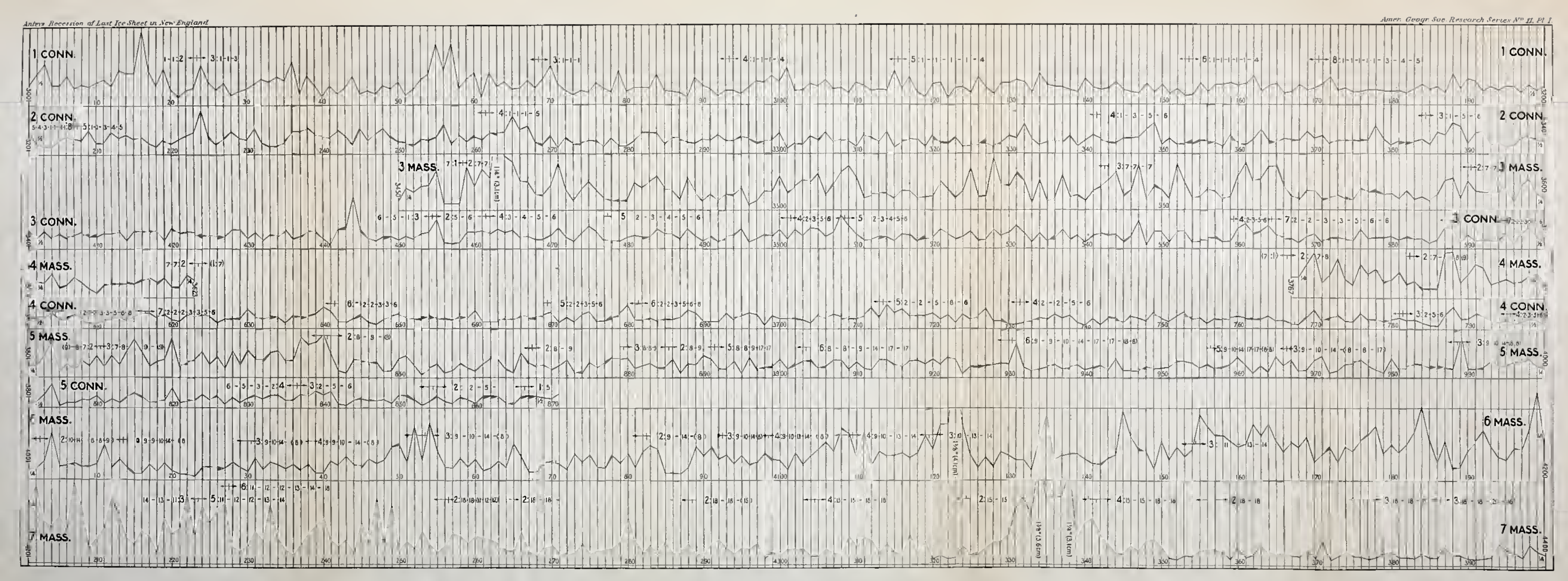



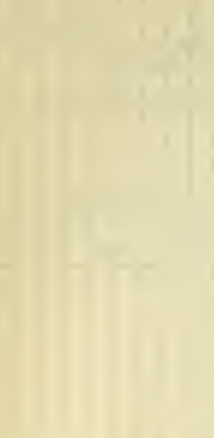

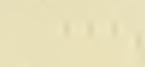

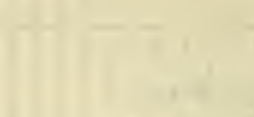

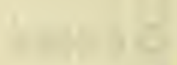$$
x^{2}+x^{2}
$$

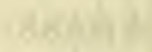

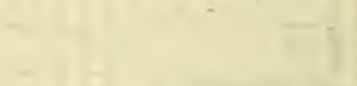

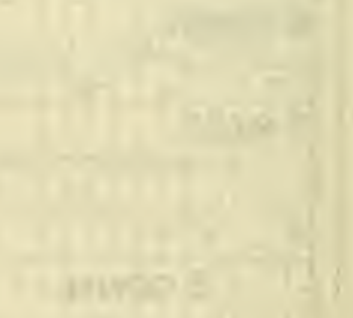

$$
\begin{aligned}
& \text { - }
\end{aligned}
$$

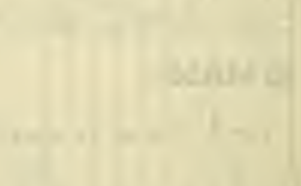

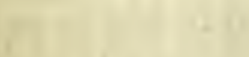



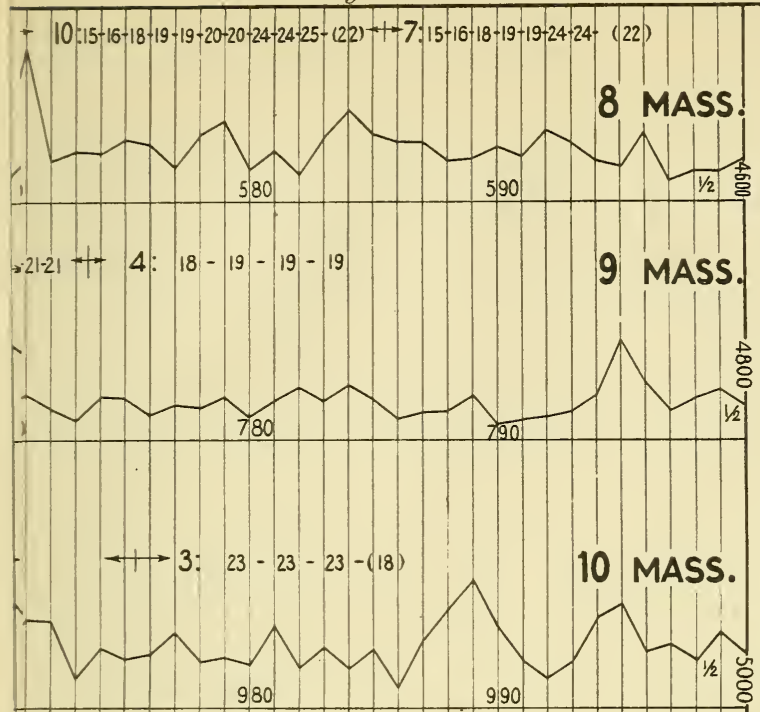

11 MASS.
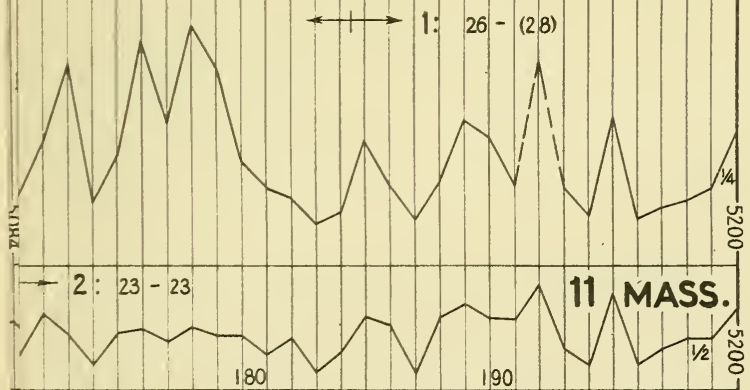

12 MASS.

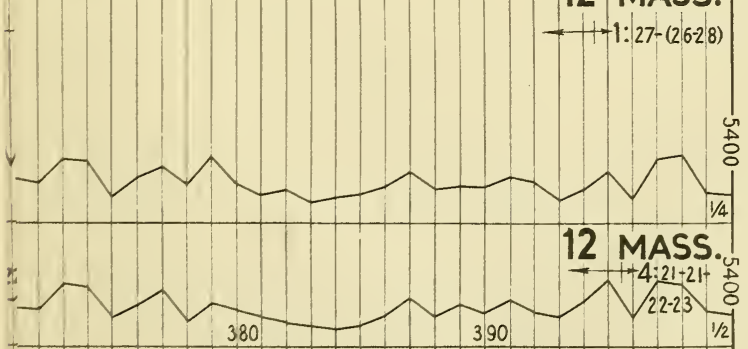





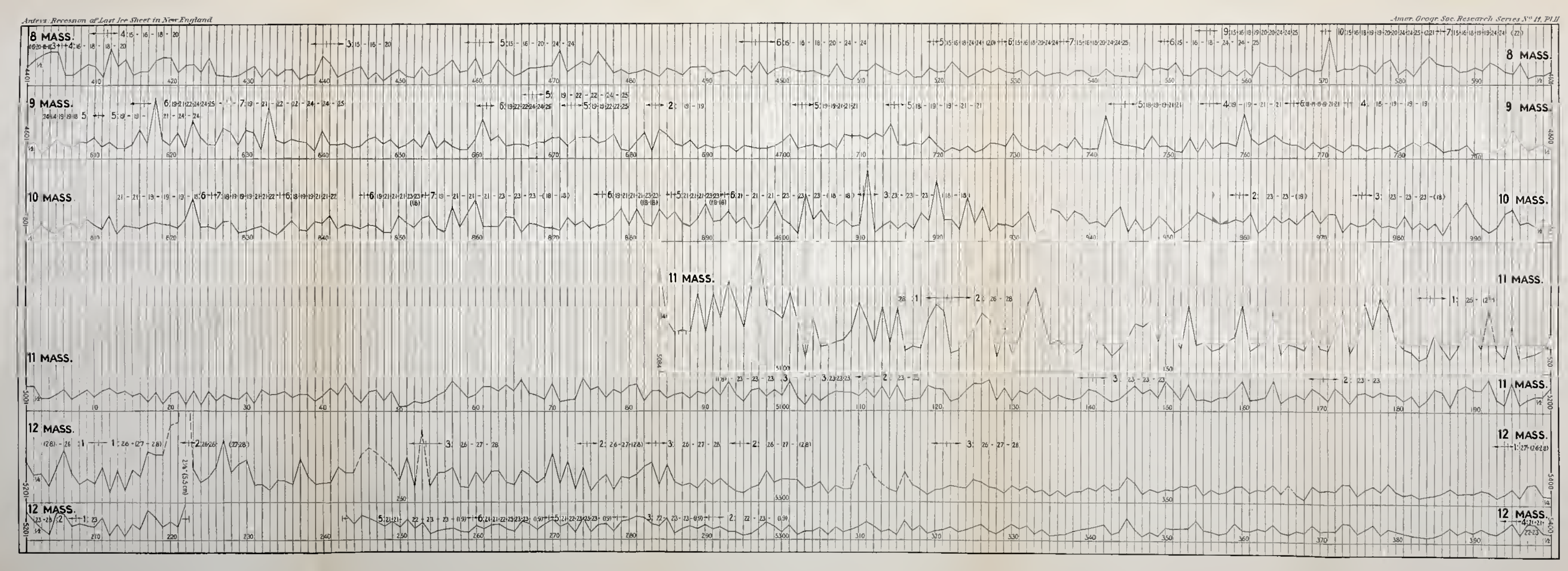




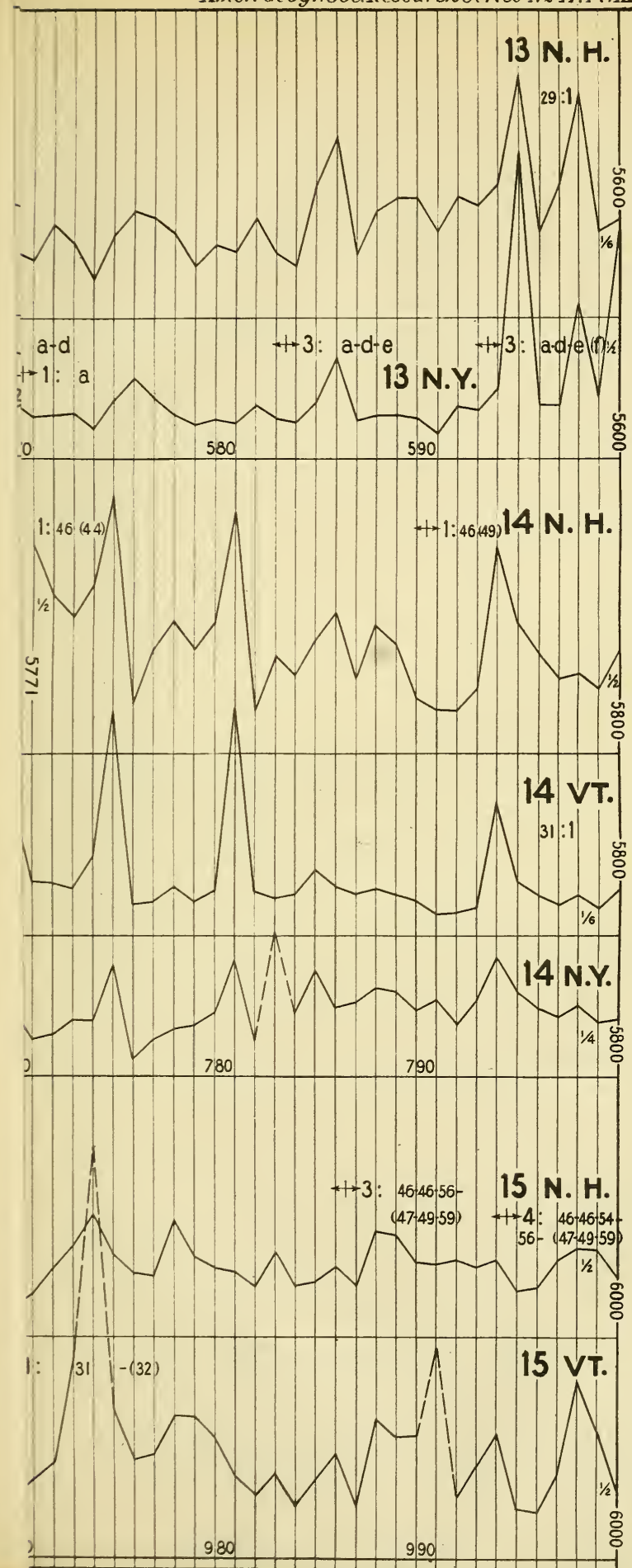




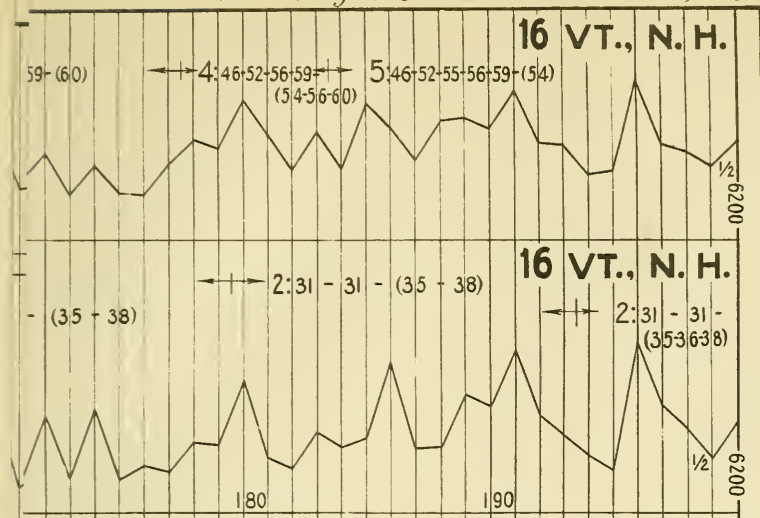




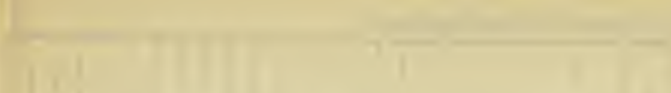

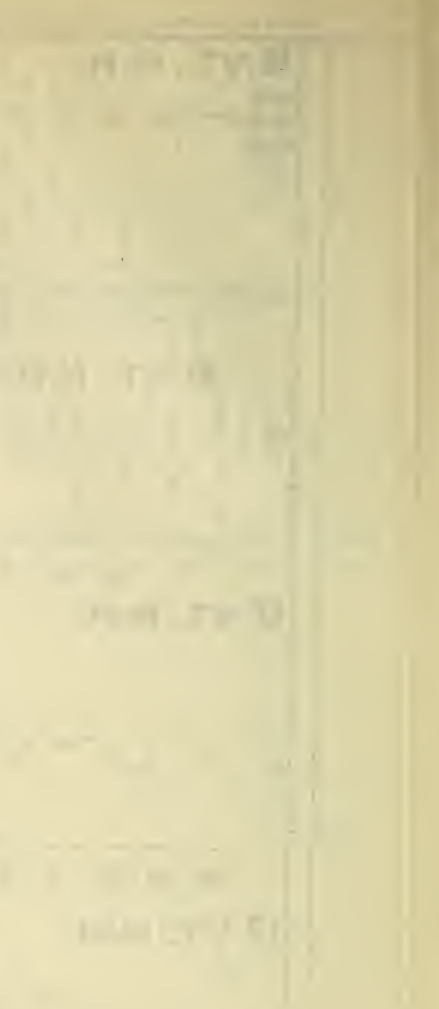




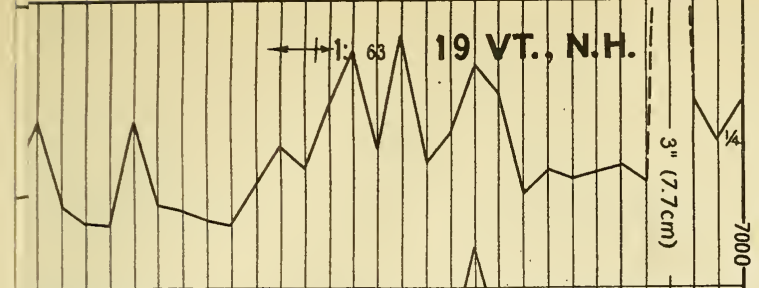

$5+75+(68+79)$

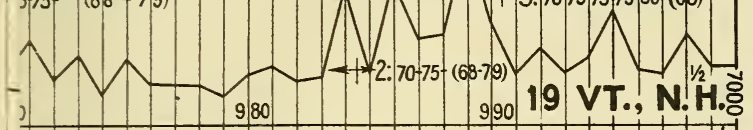
99019 VT. N! H.

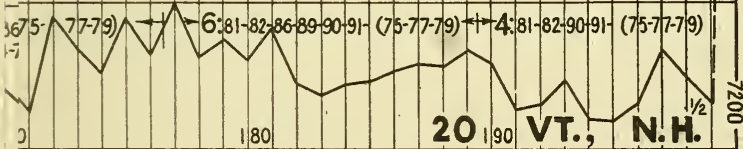

36
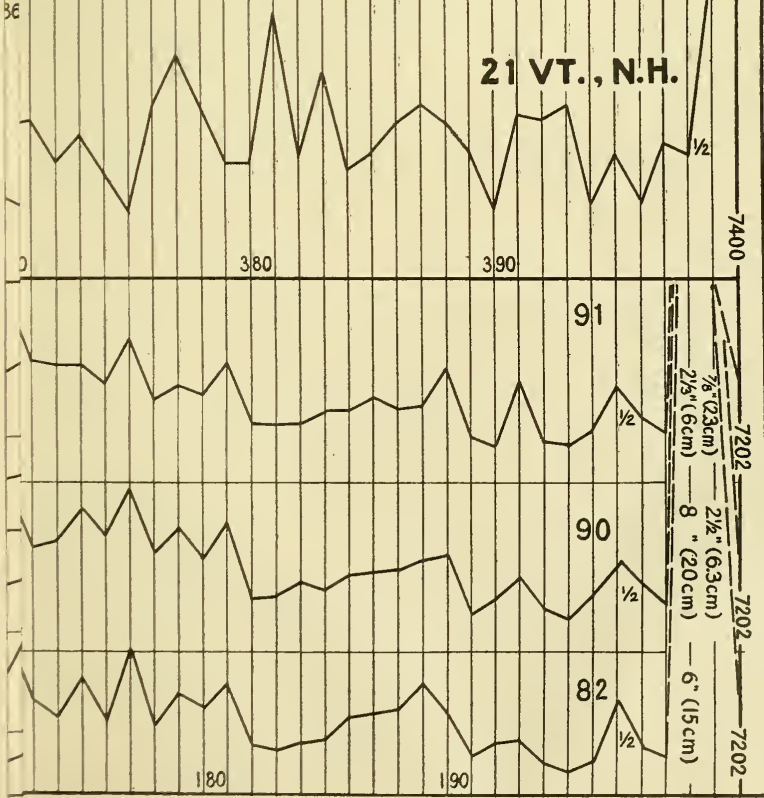





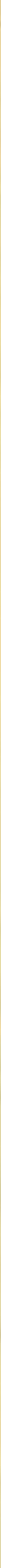





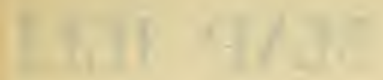

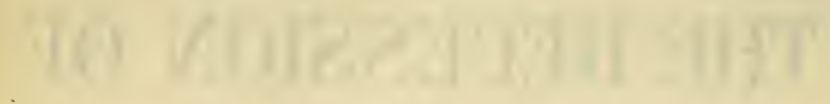

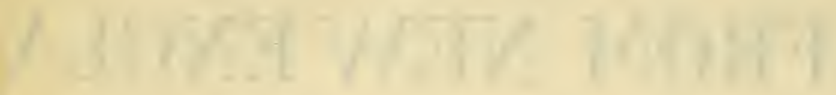






SMITHSONIAN INSTITUTION LIBRARIES 